\title{
Assessment of Hyporheic Exchange at In-stream Restoration Structures on Savage River, Garrett County, Maryland
}

Anna L. Berlinghieri

West Virginia University

Follow this and additional works at: https://researchrepository.wvu.edu/etd

\section{Recommended Citation}

Berlinghieri, Anna L., "Assessment of Hyporheic Exchange at In-stream Restoration Structures on Savage River, Garrett County, Maryland" (2013). Graduate Theses, Dissertations, and Problem Reports. 206.

https://researchrepository.wvu.edu/etd/206

This Thesis is protected by copyright and/or related rights. It has been brought to you by the The Research Repository @ WVU with permission from the rights-holder(s). You are free to use this Thesis in any way that is permitted by the copyright and related rights legislation that applies to your use. For other uses you must obtain permission from the rights-holder(s) directly, unless additional rights are indicated by a Creative Commons license in the record and/ or on the work itself. This Thesis has been accepted for inclusion in WVU Graduate Theses, Dissertations, and Problem Reports collection by an authorized administrator of The Research Repository @ WVU. For more information, please contact researchrepository@mail.wvu.edu. 


\section{Assessment of Hyporheic Exchange at In-stream Restoration Structures on Savage River, Garrett County, Maryland}
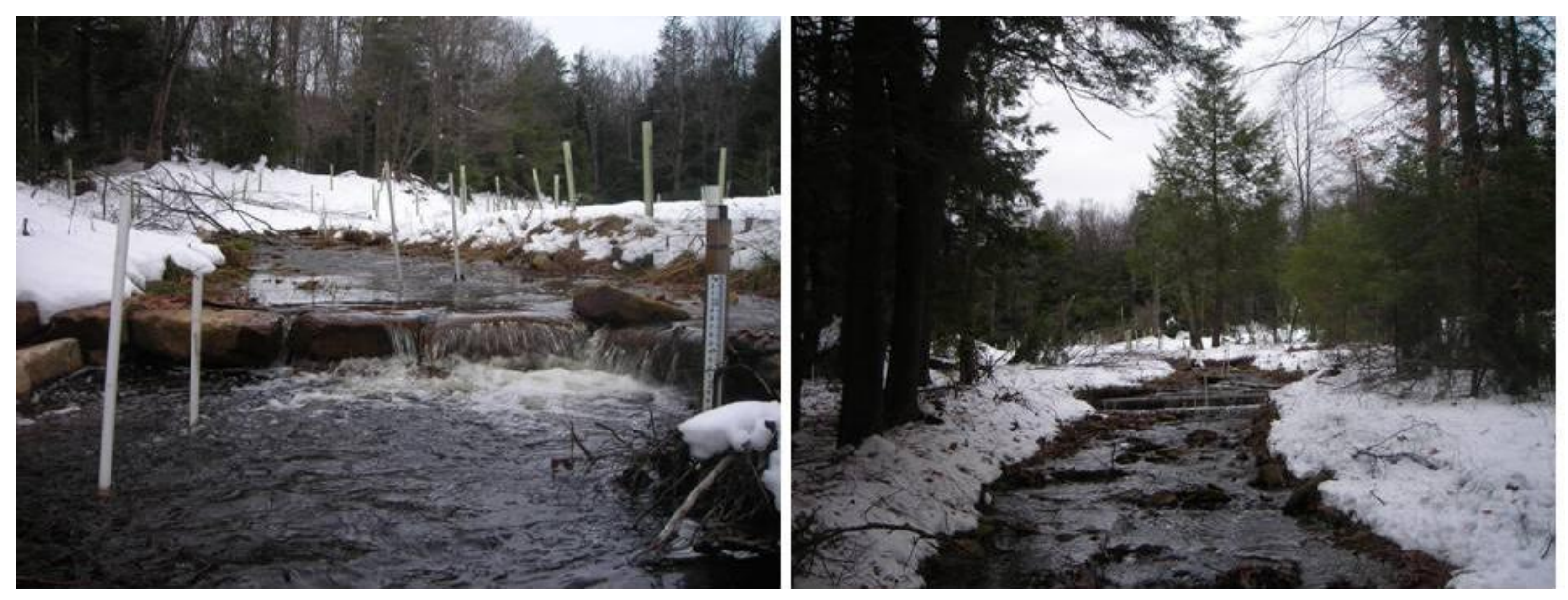

Anna L. Berlinghieri

Thesis submitted to the Eberly College at West Virginia University in partial fulfillment of the requirements for the degree of

Master of Science

in

Geology

J. Steven Kite, Ph.D., Chair

Joe Donovan, Ph.D.

Danny Welsch, Ph.D.

Nicolas Zegre, Ph.D.

Department of Geology and Geography

Morgantown, West Virginia

2013

Keywords: Hyporheic exchange, Stream restoration

Copyright 2013 Anna L. Berlinghieri 


\begin{abstract}
Assessment of Hyporheic Exchange at In-stream Restoration Structures on Savage River, Garrett County, Maryland
\end{abstract}

Anna L. Berlinghieri

Previous studies have shown that in-stream restoration structures alter hyporheic exchange dynamics in restored channels; this study assessed hyporheic exchange at a recently constructed stream reach, including the effects of in-stream restoration structures. Hydrometric and thermal data were collected in the streambed near three restoration structures and at a reference site. The hydrometric data indicated that hyporheic flow paths may not have fully developed in the first 16 months following construction; only one in-stream piezometer was unambiguously hydraulically connected to changes in stream stage. Other hydrometric data revealed possible piezometer installations in low permeability materials, potential hydraulic connections to an adjacent wetland or the pre-restoration channel, and a high degree of heterogeneity in both the subsurface material properties and the hyporheic flow patterns. A heat transport model was used to quantify vertical hyporheic fluxes from diurnal temperature fluctuations upstream and downstream of the restoration structures and at the reference site. Fluxes at the reference site were comparable in magnitude to fluxes in the constructed channel, which contrasts a previous study that found enhanced hyporheic exchange near restoration structures. Unfortunately, the sparse instrumentation network at Savage River did not allow for adequate characterization of hyporheic heterogeneities. Future work should include a denser instrumentation network to better characterize flow pattern heterogeneities as well as thorough characterization of subsurface material properties. 


\section{Acknowledgements}

I would like to express my sincere gratitude to my committee members, Dr. Steve Kite, Dr. Joe Donovan, Dr. Danny Welsch, and Dr. Nicolas Zegre, each of whom contributed valuable ideas, supplies, and field assistance in support of my thesis project. Steve, my advisor, provided guidance throughout my graduate education and persisted in finding a project for me after several setbacks. Special thanks go to Will Postlethwait of the Canaan Valley Institute for generously sharing data and information, Dr. Jaime Toro for his assistance in constructing the iButton dowels, and the City of Frostburg for land access and support of the project. The West Virginia University Department of Geology and Geography’s Graduate Field Work Fund provided funding for this project. I am deeply appreciative of fellow graduate students who helped me with field work: Valerie Beckham-Feller, Clint Davis, Amanda Laskoskie, Clayton Lilly, and Andrew Miller. I'd like to thank my family, especially my parents, for their support throughout my education. Finally, my deepest gratitude goes to my husband, Michael Berlinghieri, for his numerous hours in the field, his incredible patience throughout this process, and his willingness to accompany me on this journey to Appalachia. 


\section{Table of Contents}

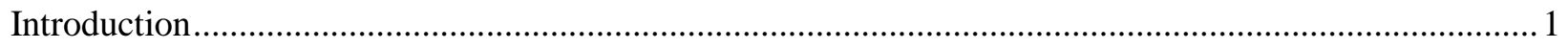

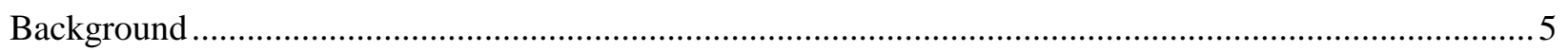

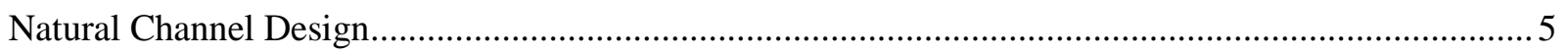

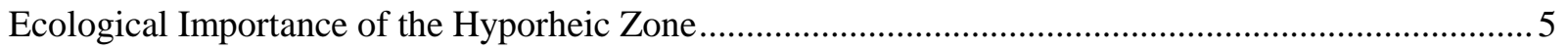

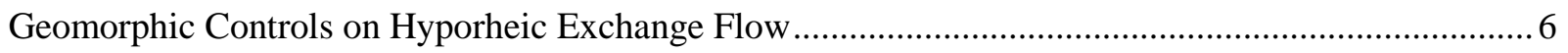

Hyporheic Exchange Flow Responses to In-Stream Restoration Structures ......................................... 8

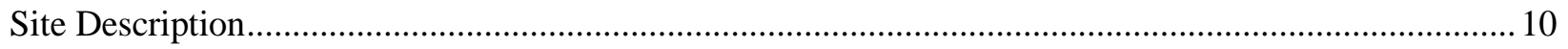

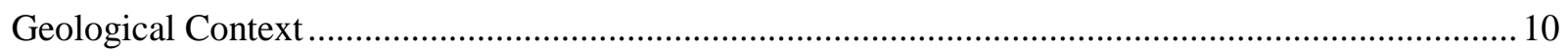

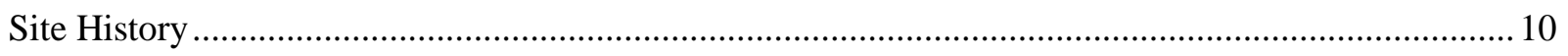

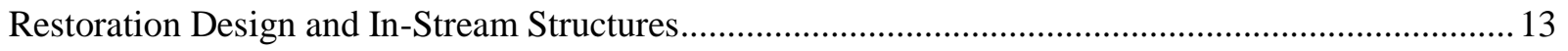

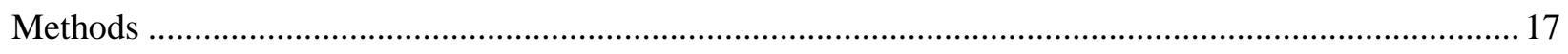

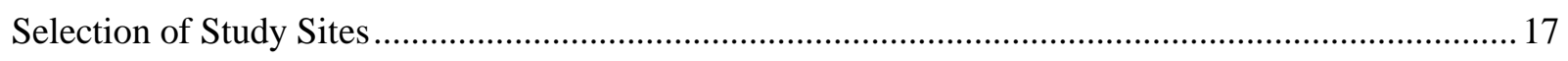

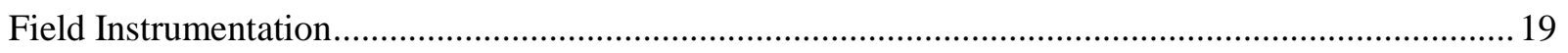

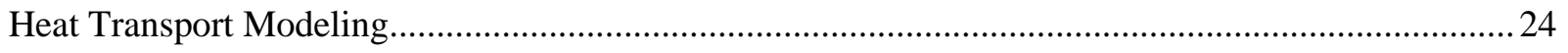

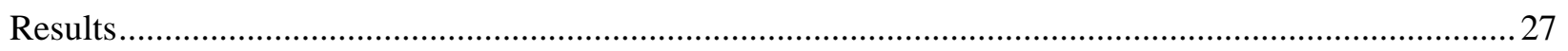

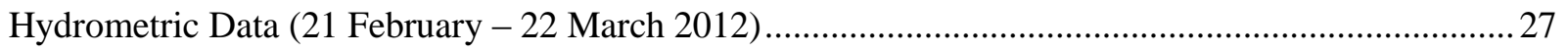

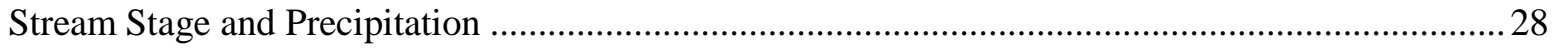

Structure 5 Piezometer Fluctuations and Stream Stage.............................................................. 30

Structure 7 Piezometer Fluctuations and Stream Stage .................................................................. 32

Reference Riffle Piezometer Fluctuations and Stream Stage ...................................................... 34

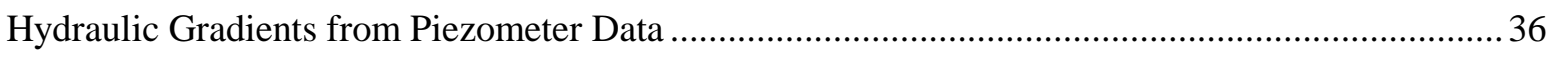

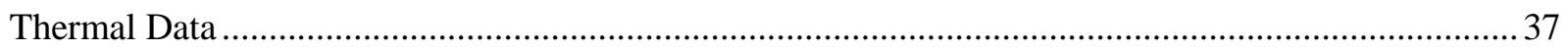

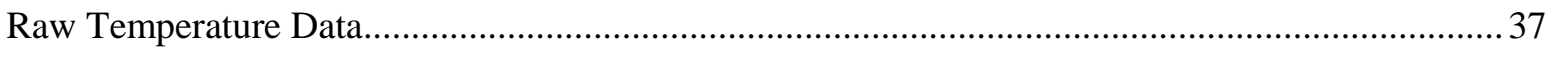

Vertical Fluxes from Heat Transport Modeling ..................................................................... 41

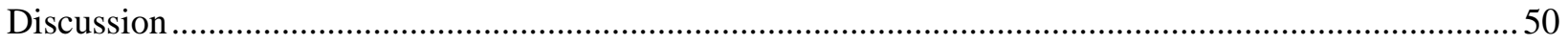

Hydraulic Connections between the Constructed Stream and the Subsurface .....................................50

Comparison of Reference Reach and Constructed Channel ............................................................54

Hyporheic Flux Patterns at Restoration Structures........................................................................ 55

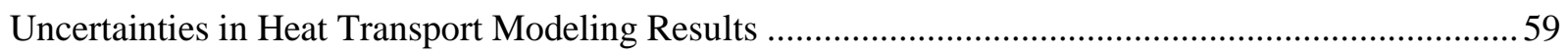

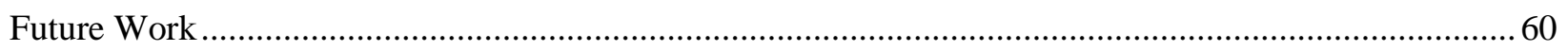

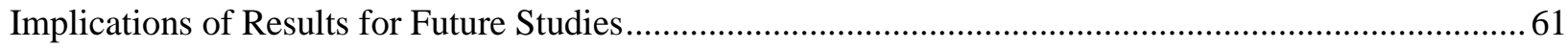

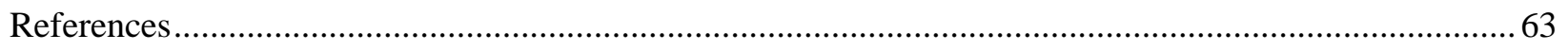

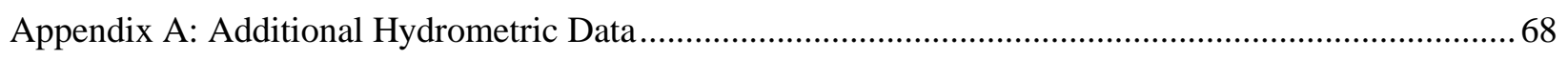

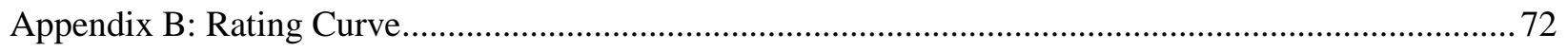

Appendix C: Manual Water Level Measurements and Hydraulic Gradients...........................................73

Appendix D: Thermal Data and Volumetric Water Flux Results ........................................................ 75 


\section{Table of Figures}

Figure 1: Study location in eastern Garrett County, Maryland ............................................................ 4

Figure 2: Geologic map of study location and surrounding area ......................................................... 11

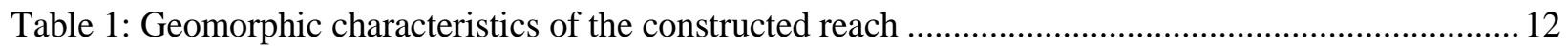

Figure 3: Restoration design by Will Postlethwait, Canaan Valley Institute ............................................ 14

Table 2: Inventory of restoration structures at the Savage River restoration site ..................................... 15

Figure 4: Plan view of log cross-vane design by Postlethwait (2010a) ................................................. 15

Figure 5: Plan view of log/rock combination J-hook vane design by Postlethwait (2010a)..................... 15

Figure 6: Plan view of log J-hook vane design by Postlethwait (2010a)............................................... 16

Figure 7: Plan view of rock J-hook vane design by Postlethwait (2010a) .............................................. 16

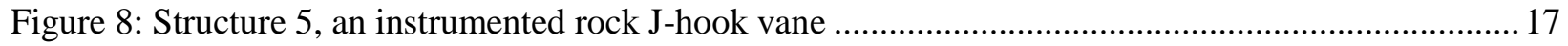

Figure 9: Structure 6, an instrumented log/rock combination J-hook vane ............................................. 18

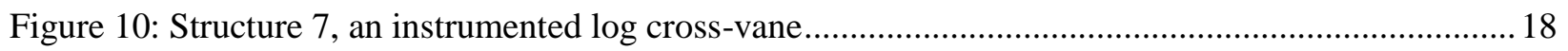

Figure 11: Reference riffle downstream from the constructed channel .................................................. 19

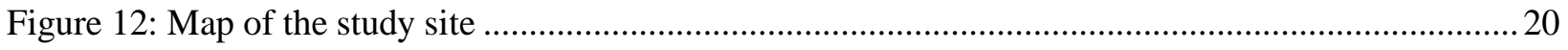

Table 3: Inventory of piezometers and pressure transducers .......................................................... 21

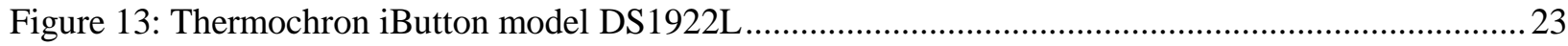

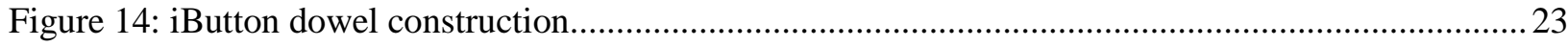

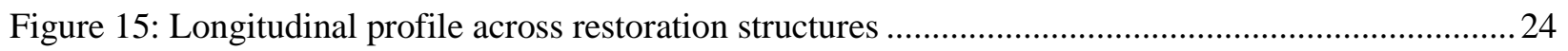

Table 4: Thermal and hydraulic parameters used in the heat transport model ........................................22

Figure 16: Precipitation amount and stream stage for 21 February through 22 March 2012 ...................29

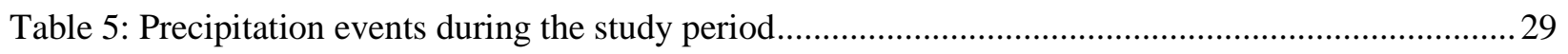

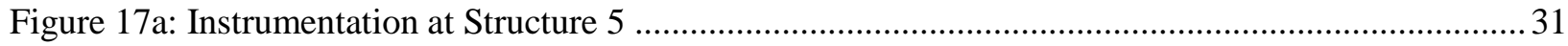

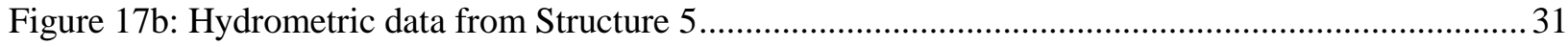

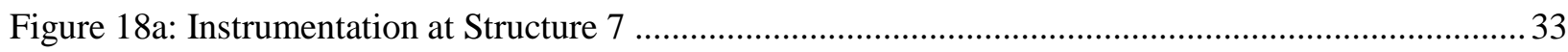

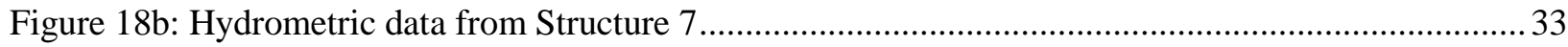

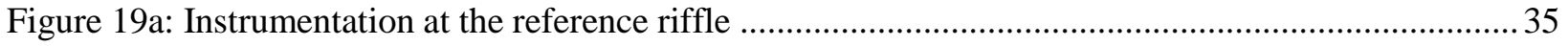

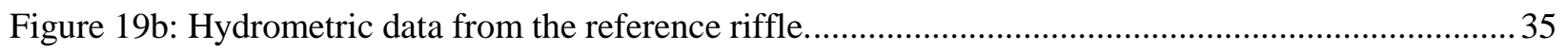

Figure 20: Vertical hydraulic gradients determined from hydrometric data........................................... 37

Figure 21: Temperature time series for 3 iButtons and hyporheic fluxes upstream of Structure 5 ............38

Figure 22: Diurnal temperature variation amplitudes for all iButtons at $0 \mathrm{~cm}$ depth .............................. 39

Figure 23: Diurnal temperature variation amplitudes for all iButtons at $5 \mathrm{~cm}$ depth ...............................40

Figure 24: Diurnal temperature variation amplitudes for all iButtons at $25 \mathrm{~cm}$ depth ............................ 40

Figure 25: Shallow and deep vertical water fluxes upstream of Structure 5......................................... 42

Figure 26: Shallow and deep vertical water fluxes downstream of Structure 5 ......................................42

Figure 27: Shallow and deep vertical water fluxes upstream of Structure 6..........................................44

Figure 28: Shallow and deep vertical water fluxes downstream of Structure 6......................................4 44

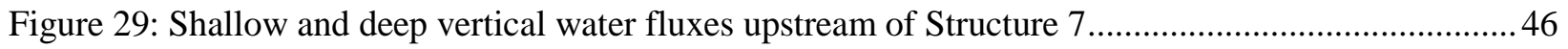




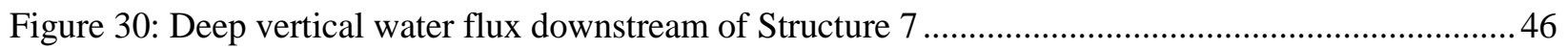

Figure 31: Shallow and deep vertical water fluxes at the reference riffle............................................. 47

Figure 32a: Map view of flux results for 22 February and potential hydraulic connections ......................48

Figure 32b: Map view of flux results for 3 March and potential hydraulic connections .......................... 49

Table 6: Water level responses to precipitation events of stream stage and Structure 7 piezometers .........52

Figure 33: Shallow fluxes upstream of restoration structures and at the reference riffle .........................56

Figure 34: Deep fluxes upstream of restoration structures and at the reference riffle .............................56

Figure 35: Shallow fluxes downstream of restoration structures and at the reference riffle ......................58

Figure 36: Deep fluxes downstream of restoration structures and at the reference riffle ........................58

Figure A1: Hydrometric data from Structure 5 for 14 September 2011 to 18 February 2012...................68

Figure A2: Hydrometric data from Structure 7 for 14 September 2011 to 18 February 2012...................69

Figure A3: Hydrometric data from reference riffle for 14 September 2011 to 18 February 2012 ............69

Figure A4: Hydrometric data from Structure 5 for 21 February to 2 November 2012 ............................ 70

Figure A5: Hydrometric data from Structure 7 for 21 February to 2 November 2012 ............................ 70

Figure A6: Hydrometric data from reference riffle for 21 February to 2 November 2012 ….................. 71

Figure B1: Relationship between stream stage and discharge for gage downstream of Structure 6 ..........72

Table C1a: Hydraulic heads measured manually on 2 March 2012 ........................................................ 73

Table C1b: Hydraulic heads measured manually on 11 March 2012 .................................................. 73

Table C2: Vertical hydraulic gradients for in-stream pairs of nested piezometers .................................. 74

Figure D1: Temperature time series for 3 iButtons and hyporheic fluxes upstream of Structure 5 .......... 75

Figure D2: Temperature time series for 3 iButtons and hyporheic fluxes downstream of Structure 5.......75

Figure D3: Temperature time series for 3 iButtons and hyporheic fluxes upstream of Structure 6 ...........76

Figure D4: Temperature time series for 3 iButtons and hyporheic fluxes downstream of Structure $6 \ldots . . . .76$

Figure D5: Temperature time series for 3 iButtons and hyporheic fluxes upstream of Structure 7 .......... 77

Figure D6: Temperature time series for 3 iButtons and hyporheic fluxes downstream of Structure $7 \ldots \ldots . .77$

Figure D7: Temperature time series for 3 iButtons and hyporheic fluxes at the reference riffle ...............78 


\section{Introduction}

Billions of dollars are spent annually on stream restoration in the United States despite uncertainty in its effectiveness and heavy criticisms of restoration strategies (Bernhardt et al., 2005; Lave et al., 2008). Dissension exists between restoration practitioners and academicallytrained fluvial geomorphologists regarding the connectivity between restoration science and implementation, appropriate restoration goals, the scale at which restoration should be performed, and the methods through which restorations should be evaluated (Wohl et al., 2005; Lave et al., 2010). Natural Channel Design, a popular restoration strategy in the United States, is at the forefront of this debate (Lave et al., 2010).

Every completed restoration project provides a potential opportunity to analyze the response of stream systems to restoration and to progress restoration science and the debate. Unfortunately, only a small percentage of restoration projects in the United States have any form of post-construction assessment (Bernhardt et al., 2005). While many strategies, including Natural Channel Design, have the potential to succeed in achieving restoration goals, the lack of post-construction monitoring undermines the advancement of restoration science and fuels the fire between academia and the private sector. People on both sides of the debate are pushing for increased monitoring and assessment of completed projects in order to better inform future project designs (Bernhardt et al., 2005; Hasset et al., 2005; Wohl et al., 2005; Lave et al., 2009). Given the continued relevance and intense criticism of Natural Channel Design, it is important to critically evaluate the physical responses of streams restored via Natural Channel Design methods.

One aspect of Natural Channel Design often criticized is channel stabilization through the use of in-stream restoration structures, such as cross-vanes and J-hook vanes (Kondolf et al., 
2001; Lave et al. 2010). Opponents of Natural Channel Design argue that natural streams are inherently unstable and channel migration is beneficial for ecosystem dynamics, so in-stream structures hamper ecosystem function (Kondolf et al., 2001). As the lead proponent of Natural Channel Design, Rosgen (2006) claims that restoration structures achieve desirable ecosystem effects through the creation of deep pools and bank cover for fish refuge. These divergent claims call for assessment of ecosystem function following restorations using in-stream structures.

Improving ecosystem function is a common goal of stream restoration and may include such activities as removing barriers to fish passage or altering streambed complexity to increase habitat diversity (Bernhardt et al., 2007). The hyporheic zone, or the aquifer directly adjacent to and hydraulically connected to the stream, is a vital component of stream ecosystems that has been largely ignored in restorations to date (Hester and Gooseff, 2010). The movement of stream water into and out of the streambed, a process known as hyporheic exchange, provides several crucial ecosystem functions, including nutrient cycling, pollutant buffering, water temperature regulation and macroinvertebrate habitat (Hester and Gooseff, 2010). Hester and Gooseff (2010) argue that a sustainable approach to stream and ecosystem restoration must include consideration of the hyporheic zone, thus necessitating that post-construction assessment include quantification of hyporheic responses to restoration.

Studies have shown that in-stream restoration structures alter hyporheic exchange dynamics in channels that have undergone restoration activities including meander recreation and bank stabilization (Crispell and Endreny, 2009; Lautz et al., 2010; Daniluk et al., 2012; Gordon et al., in press). In these studies, the restorations modified existing stream channels, so hyporheic flow paths established prior to restoration were potentially still active after restoration. Alternatively, some restoration projects involve full-scale redesign and construction of a new 
channel; in these circumstances, pre-established hyporheic flow paths may be disrupted or destroyed, or the new channel's location may be far removed from the old channel's hyporheic zone. The purpose of this study was to assess hyporheic exchange at a recently constructed stream reach, including the effects of in-stream restoration structures.

A headwater reach of Savage River in Garrett County, Maryland, (Figure 1) was constructed in fall 2010 to bypass an inoperative dam. The constructed channel was designed using Natural Channel Design methods, and in-stream restoration structures were installed to achieve channel stabilization (Postlethwait, 2011). Thus, this stream reach allowed for assessment of hyporheic exchange dynamics in a newly constructed stream reach and around instream restoration structures. It was not the purpose of this study to give merit to or discount any single approach to stream restoration. Rather, this project investigated hyporheic functions of a stream reach restored via Natural Channel Design methods.

This study was guided by the following research questions:

- Does the recently constructed stream channel have a functioning hyporheic zone?

- If not, what controls subsurface hydraulic dynamics near the constructed channel?

- How does the presence of restoration structures impact hyporheic responses to changes in stream stage?

- How does hyporheic exchange magnitude differ between the constructed reach and an unrestored "natural" reference riffle? 


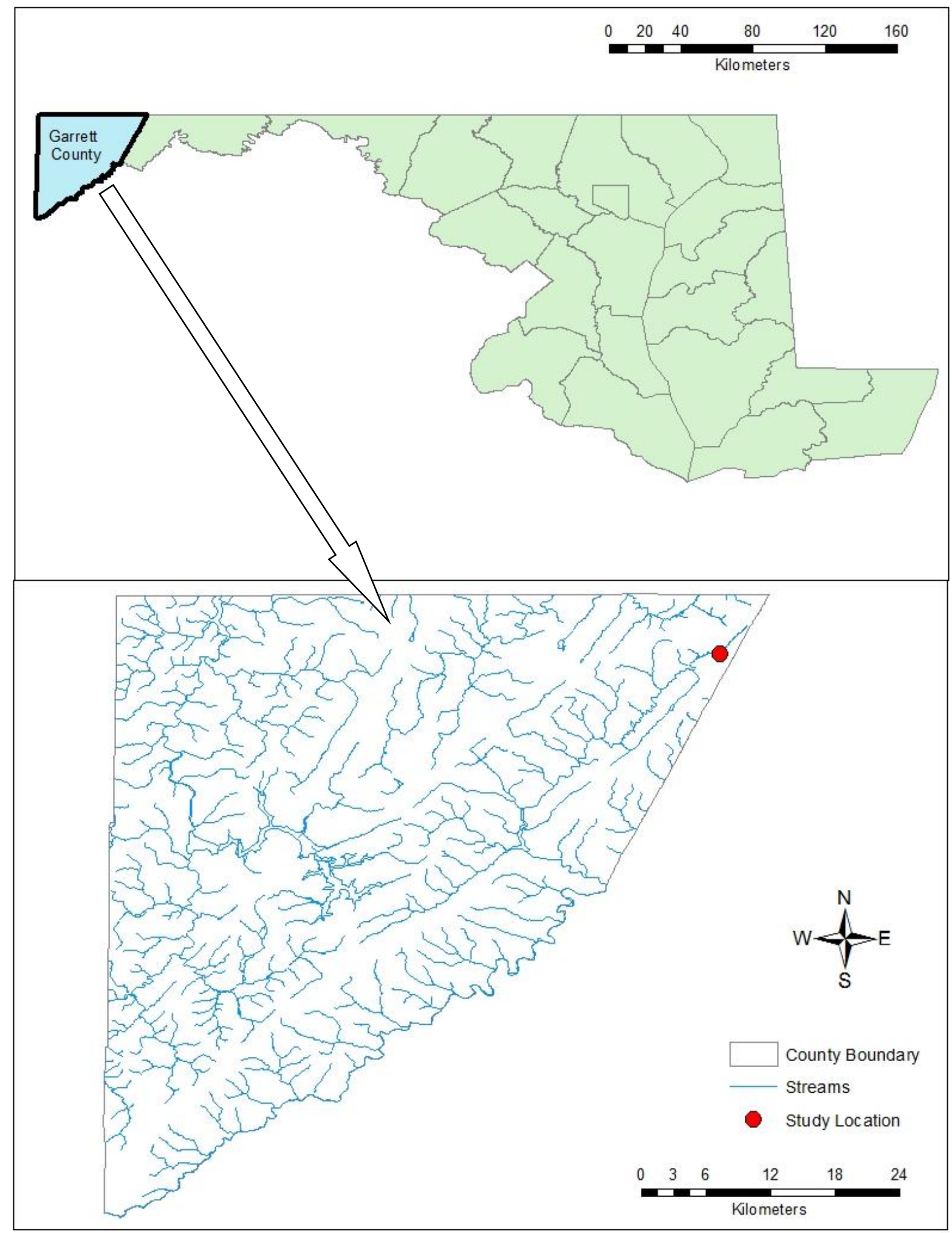

Figure 1: Study location in eastern Garrett County, Maryland. The study site is located on a recently constructed reach of Savage River. Shapefiles from US Census Bureau and USDA NRCS. 


\section{Background}

\section{Natural Channel Design}

Many federal and state agencies have adopted Natural Channel Design approaches to stream restoration, leading to its increasing relevance in the stream restoration community (Lave, 2008). This restoration strategy was derived from the concept that the dimension, pattern and profile of a naturally stable stream can be used to design a restoration project on a geomorphically similar, unstable stream (Rosgen, 1994).

As the lead proponent of Natural Channel Design, Rosgen (2006) promotes the use of instream structures, such as cross-vanes and J-hook vanes, in stream restoration. These structures are designed to meet specific functional objectives. Cross-vanes direct energy away from the banks and into the thalweg, thereby reducing bank erosion and maintaining channel capacity and sediment transport capacity. Additionally, cross-vanes provide deep pools for fish refuge, spawning habitat in the glide portion of the pool and increased bank cover resulting from a higher water surface near the bank (Rosgen, 2006). J-hook vanes reduce bank erosion on the outside of meander bends by directing the maximum velocity, shear stress and stream power to the center of the channel. The hook portion of J-hook vanes creates a long, wide and deep pool, which dissipates energy and provides fish habitat. Gaps are commonly left in the hook to create vortices that increase shear stress, promoting sediment transport and maintaining channel capacity (Rosgen, 2006).

\section{Ecological Importance of the Hyporheic Zone}

The hyporheic zone includes any subsurface material saturated by waters that interact hydraulically with the stream channel. The hyporheic zone can alternatively be defined as the 
groundwater zone imbued with stream organisms, where biogeochemical dynamics are linked with chemistry in the active stream channel (Stanford and Ward, 1993). Hyporheic exchange plays an important role in ecosystem dynamics, especially biogeochemical processes.

Findlay (1995) concluded that the physical constraints on hyporheic exchange play a larger role than microbial abundance, the rates of biotic processes, or temperature in stream ecosystem dynamics. Findlay (1995) also argued that a better understanding of the hydrology of hyporheic exchange is needed in order to constrain biogeochemical processes. Therefore, it is important to characterize hyporheic exchange flux and residence time in order to understand a stream's ecosystem dynamics.

Hester and Gooseff (2010) discussed the lack of consideration for the hyporheic zone in most stream restoration projects, despite its documented importance to ecosystem function. They suggested a number of potential hyporheic restoration techniques to be implemented as part of a more holistic and sustainable approach to stream restoration. They argued that, before these techniques can be employed, the effects of various restoration techniques on hyporheic exchange need to be further assessed and quantified (Hester and Gooseff, 2010).

\section{Geomorphic Controls on Hyporheic Exchange Flow}

Harvey and Bencala (1993) used steady-state, conservative tracer experiments to show that streambed topography is a major controlling factor in hyporheic exchange dynamics in unrestored streams, confirming what had previously been shown in flume studies (Savant, 1987). Their results indicated that stream water entered the subsurface at the downstream end of pools, flowed through the subsurface for 1 to $10 \mathrm{~m}$ along the steeper riffle channel unit, and returned to the stream at the upstream end of the next pool. They also found seasonal variability in flow 
paths; mainly, when hillslope groundwater contributions were high, the effect of streambed topography on hyporheic exchange decreased (Harvey and Bencala, 1993).

Many studies elaborated on the relationship between geomorphic features and hyporheic exchange responses, including the effects of channel sinuosity (Wroblicky et al., 1998), paleochannels (Stanford and Ward, 1988), changes in channel constraint (Stanford and Ward, 1993; Wondzell and Swanson, 1999; Kasahara and Wondzell, 2003), channel size and order (Kasahara and Wondzell, 2003), and seasonal changes in stream stage (Wondzell and Swanson, 1996). More recently, studies have explored the relationship between hyporheic exchange flow and manmade geomorphic structures, such as weirs (Hester and Doyle, 2008), dams (Lautz et al., 2010), constructed gravel bars (Kasahara and Hill, 2008), constructed riffle-pool sequences (Kasahara and Hill, 2008) and in-stream restoration structures (Crispell and Endreny, 2009; Gordon et al., in press).

Hester and Doyle (2008) modeled hyporheic exchange dynamics around hypothetical geomorphic structures, varying the structure characteristics to assess model sensitivity. Their results indicated that structures induced a single hyporheic flow cell approximately 2 channel widths long with downwelling upstream of the structure and upwelling downstream of the structure. The size and magnitude of the flow cell were affected most significantly by the step height and lateral width of the structure, the background groundwater discharge and the hydraulic conductivity (Hester and Doyle, 2008).

Lautz et al. (2010) used a heat transport model, described by Hatch et al. (2006), to characterize the spatial heterogeneity of hyporheic exchange at two dams and a stream meander. Vertical arrays of temperature sensors were installed in the streambed upstream and downstream of each structure. The thermal data were used to determine vertical seepage flux through the 
streambed; the flux results were combined with water level measurements from piezometers to determine vertical hydraulic gradients at multiple depths. Lautz et al.'s (2010) results revealed heterogeneities in vertical hyporheic exchange:

1. Upstream of impoundments that trap fine sediments, hyporheic exchange was nearly static, and a large, downward vertical hydraulic gradient developed.

2. In coarse-bed sediments underlain by lower hydraulic conductivity sediments, a shallow, rapidly-exchanging hyporheic zone developed, with slow to no exchange deeper in the streambed.

3. Rapid downwelling occurred through the hyporheic zone at locations of strong recharge to groundwater in heterogeneous streambeds, but flux was variable with depth.

Lautz et al. (2010) argued that heat transport modeling identified vertical heterogeneities in the hyporheic zone that would not be detected by other methods, such as measurements of hydraulic head at only one depth in a piezometer.

\section{Hyporheic Exchange Flow Responses to In-Stream Restoration Structures}

Several studies used heat transport modeling to assess hyporheic exchange dynamics around in-stream restoration structures (Crispell and Endreny, 2009; Daniluk et al., 2012; Gordon et al., in press).

Crispell and Endreny (2009) used heat transport modeling to assess hyporheic exchange patterns and rates around cross-vanes and J-hook vanes on a third-order stream in the Catskill Mountains of New York. At baseflow, all structures exhibited similar hyporheic exchange patterns: upwelling in the run induced by the structure, a transition zone in the pool downstream of the structure, and downwelling in the glide downstream of the pool. Simulated higher flow 
scenarios varied between structures, but each structure exhibited a distinct hyporheic exchange pattern with increasing discharge. For instance, simulations showed that as discharge increased over one of the J-hook vanes, the length of the upstream upwelling zone increased and the length of the downwelling in the upstream riffle decreased (Crispell and Endreny, 2009).

Gordon et al. (in press) assessed vertical hyporheic flux and redox conditions around four boulder cross-vanes on three restored lowland streams in New York. Their results indicated complex patterns of hyporheic exchange around cross-vanes that were influenced by secondary bedforms near the structures. They found rapid downwelling immediately upstream and variable fluxes and redox conditions downstream of the cross-vanes. Small, heterogeneous patches of upwelling and downwelling were identified both upstream and downstream of the cross-vanes and were associated with secondary pool and riffle bedforms. These results contrasted the single hyporheic flow cell scenario suggested by Hester and Doyle (2008) and Crispell and Endreny (2009).

Daniluk et al. (2012) used heat transport modeling and geochemical analyses to compare hyporheic exchange at boulder cross-vanes with a reference reach used to design the restoration project. They found rapid flux immediately adjacent to the structures, high dissolved oxygen, and reduction of sulfate and nitrogen at the restoration sites - none of which were found at the reference sites. The authors concluded that restoration enhanced hyporheic exchange at both of their study sites compared to the reference reaches (Daniluk et al., 2012).

This thesis project built upon the studies above by utilizing heat transport modeling and hydrometric data to describe hyporheic exchange at restoration structures in a recently constructed channel, rather than a restored channel. Additional data collected at a reference site allowed for comparison between the constructed reach and an unrestored reach on Savage River. 


\section{Site Description}

\section{Geological Context}

Savage River is located in the Allegheny Mountain Section of the Appalachian Plateaus province within the Potomac River watershed (Fenneman, 1928; Amsden et al., 1954). Most of the Savage River watershed is characterized by broadly rolling uplands with deeply incised stream valleys (Nutter et al., 1980). Savage River's headwaters lie in Cranberry Swamp (also known as Finzel Swamp), located southeast of the town of Finzel, Maryland (Figure 2). From the headwaters to the constructed reach described in this document, Savage River flows in the valley west of Big Savage Mountain and east of Little Savage Mountain. Geomorphic characteristics of the constructed reach, as designed and as built, are given in Table 1.

The bedrock of the watershed includes Mississippian and Pennsylvanian sedimentary rocks brought to the surface through the erosion of broad, northeast-trending Deer Park Anticline (Brezinski, 1988). The bedrock of the upper Savage River valley includes both the Mississippian Pocono and the Mississippian Greenbrier formations (Figure 2). The Mississippian Greenbrier Formation consists of interbedded marine sandstone, siltstone, shale and limestone (Brezinski, 1988). The Mississippian Pocono Formation is primarily coarse-grained sandstone with conglomeratic lenses and minor shale interbeds, and it is a major aquifer in the Deer Park Anticline (Nutter et al., 1980; Brezinski, 1988).

\section{Site History}

The City of Frostburg, Maryland, began collecting groundwater from wells in the Mississippian Pocono Formation in the Savage River valley in the nineteenth century (Nutter et al., 1980). In the early 1900s, the City of Frostburg built an impoundment on upper Savage 


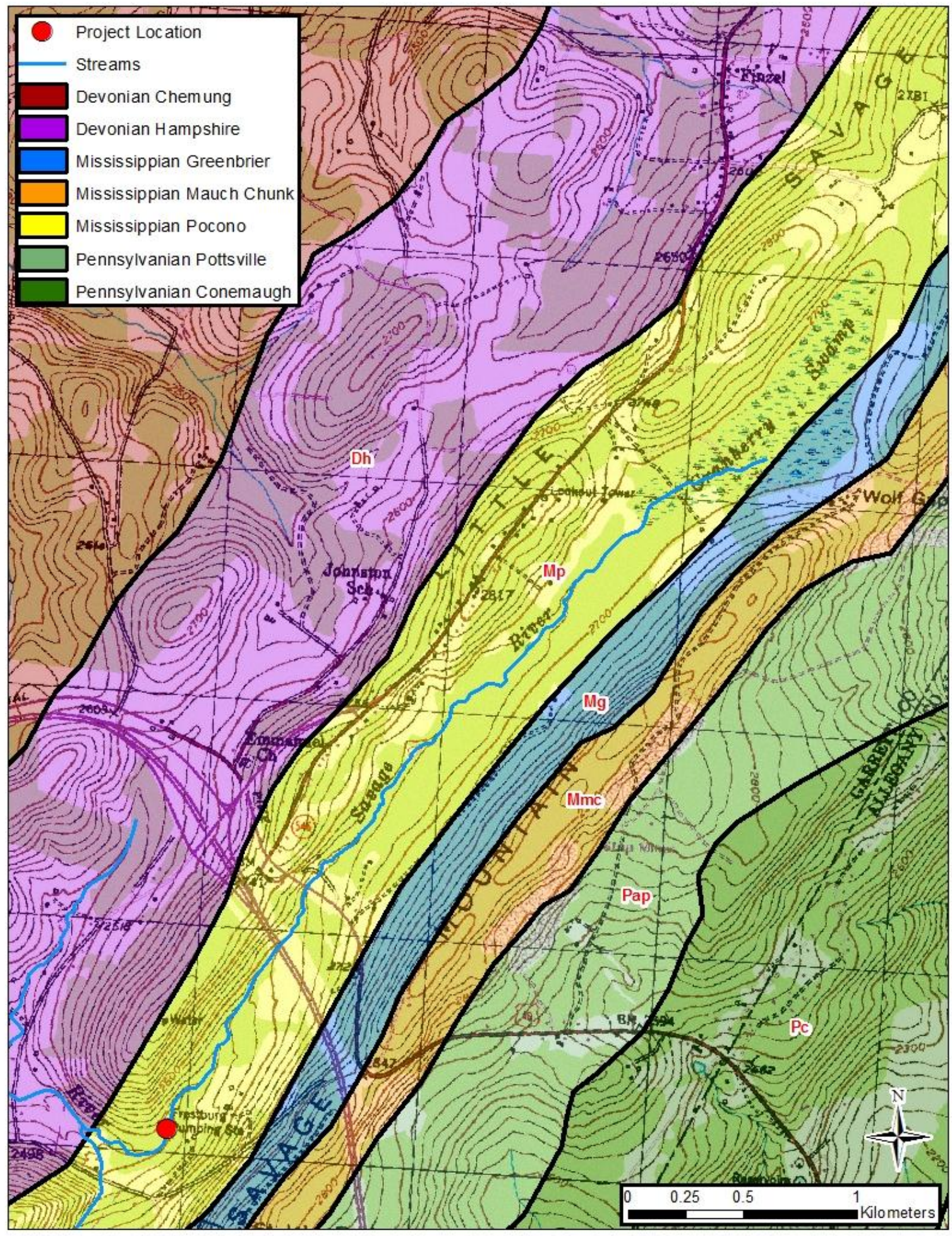

Figure 2: Geologic map of study location and surrounding area. The study location is approximately 3.5 $\mathrm{km}$ downstream of Savage River's headwaters (Cranberry Swamp, northeast corner of map). Bedrock in the stream valley includes Mississippian Pocono Sandstone and Mississippian Greenbrier Limestone. Shapefiles from Dicken et al. (2005), US Census Bureau and USDA NRCS. 


\begin{tabular}{|l|r|r|}
\hline \multicolumn{1}{|c|}{ Characteristic } & As Designed & As Built \\
\hline Distance from Headwaters $(\mathrm{km})$ & 3.5 & 3.5 \\
\hline Elevation $(\mathrm{m})$ & 762 & 762 \\
\hline Drainage Area $\left(\mathrm{km}^{2}\right)$ & 5.05 & 5.05 \\
\hline Length of Restored Reach $(\mathrm{m})$ & 213.36 & 201.17 \\
\hline Stream Type & $\mathrm{C} 3$ & $\mathrm{C} 3$ \\
\hline Bankfull Width $(\mathrm{m})$ & 6.87 & 7.68 \\
\hline Bankfull Mean Depth $(\mathrm{m})$ & 0.27 & 0.27 \\
\hline Bankfull Discharge $\left(\mathrm{m}^{3} / \mathrm{s}\right)$ & 1.53 & $\mathrm{NR}$ \\
\hline Flood-prone area $(\mathrm{m})$ & 18.29 & 30.48 \\
\hline Entrenchment Ratio & 2.66 & 3.97 \\
\hline Sinuosity & 1.12 & 1.12 \\
\hline Valley Slope $(\mathrm{m} / \mathrm{m})$ & 0.02 & $\mathrm{NR}$ \\
\hline
\end{tabular}

Table 1: Geomorphic characteristics of the constructed reach. 'As Designed' values were determined by Canaan Valley Institute based on a reference reach of Savage River downstream of the study site. 'As Built' values were calculated by Canaan Valley Institute based on a survey performed just after construction. 'NR' = data not reported (Postlethwait, 2010b).

River to supplement the groundwater collection. Although the impoundment was abandoned in 1986, the dam remained in place (Postlethwait, 2011).

In 2006, the Maryland Department of Natural Resources (MDNR) listed brook trout (Salvelinus fontinalis) as a "Species in Greatest Need of Conservation," and Savage River was identified as a brook trout resource in need of improvement. Brook trout require stream temperatures below $21^{\circ} \mathrm{C}\left(70^{\circ} \mathrm{F}\right)$ to survive, making them especially sensitive to increased water temperatures at several impoundments on Savage River. MDNR fisheries biologists found that temperatures at the City of Frostburg's impoundment exceeded $24^{\circ} \mathrm{C}\left(75^{\circ} \mathrm{F}\right)$ downstream of the dam, but remained below $18^{\circ} \mathrm{C}\left(65^{\circ} \mathrm{F}\right)$ above the dam. Thus, the temperatures downstream of the dam were unsuitable for brook trout survival; in addition, the dam blocked fish passage to the cooler headwaters. In 2009, MDNR and Savage River Watershed Association contacted Canaan Valley Institute (CVI) to design a restoration project (Postlethwait, 2011). 


\section{Restoration Design and In-Stream Structures}

CVI used Natural Channel Design techniques to design a new channel, bypassing the dam along the reservoir's northwest edge (Figure 3). The dam was buried, and the former reservoir was converted to an emergent scrub-shrub wetland to provide wildlife habitat, water quality improvement and flood storage. Construction was completed in November 2010 (Postlethwait, 2010b).

A total of ten in-stream structures were installed on the new channel to provide aquatic habitat and streambank stability. Four different types of structures were used: log-rock combination J-hook vanes, log cross-vanes, log J-hook vanes, and a rock J-hook vane (Figure 3; Table 2) (Postlethwait, 2010b).

Log cross-vanes were constructed with two log arms; the cut ends of the logs were buried in the streambed at one third (1/3) to one-half (1/2) the channel width and the root ends were buried in the banks at the level of half-bankfull stage (Figure 4). Woven geotextile was attached to the logs on their upstream side to hold fill material in place behind the logs. Anchor stones were installed at the upstream end of the structure, and sill logs were buried in the banks at the rooted ends of the arms. Scour pools were excavated downstream of the log cross-vanes (Postlethwait, 2010a).

The log-rock combination J-hook vanes were built with one log arm and a 'hook' between the log and the opposite bank constructed out of boulders (Figure 5). Additional boulders were placed directly on top of the log for weight. Sill logs and rocks were buried into the banks. Scour pools were excavated on the downstream side of each structure, and a root wad extended from the sill log into the pool (Postlethwait, 2010a).

The log J-Hook vanes were constructed with one log arm and a log step between the arm 


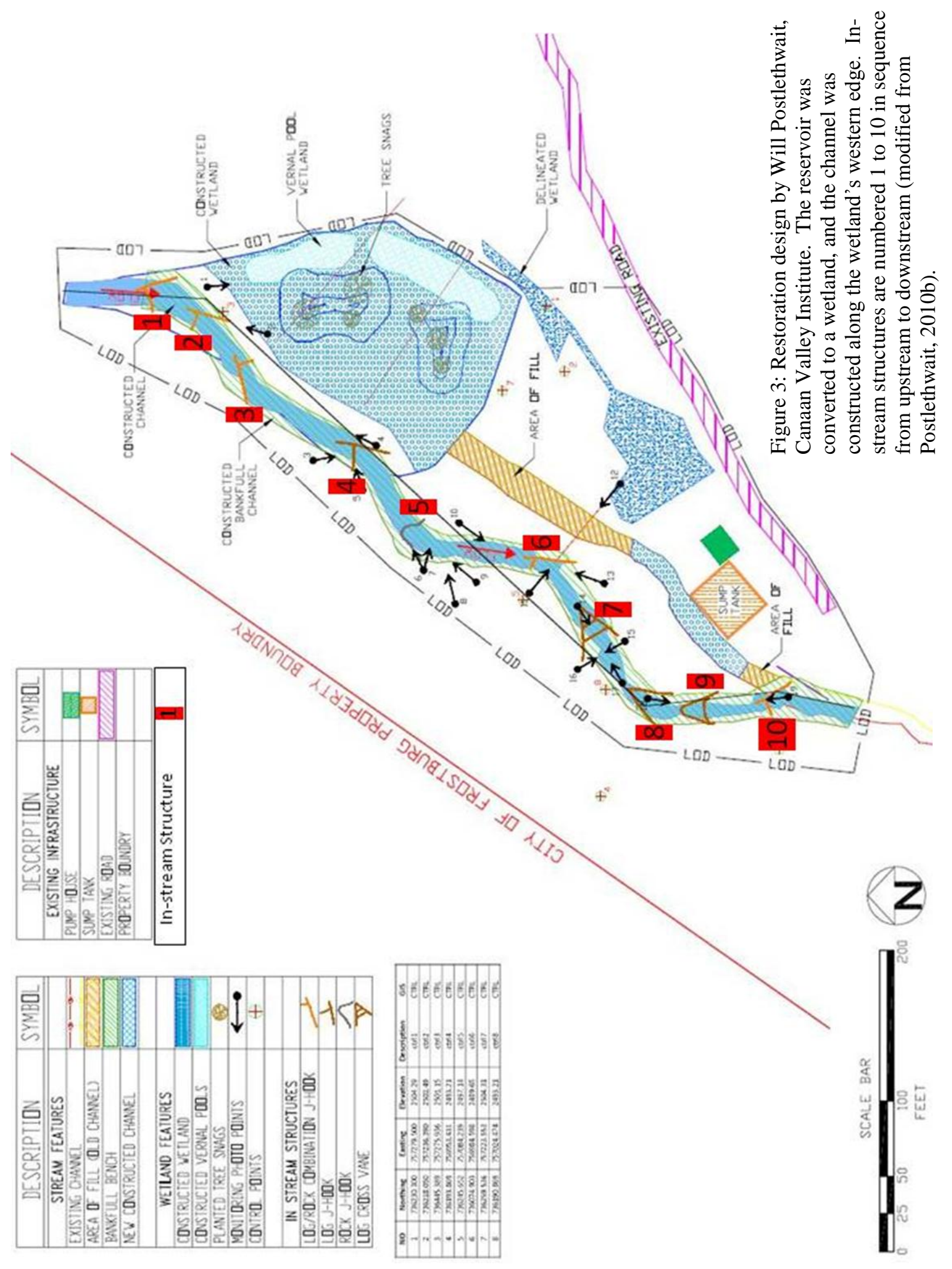


Table 2: Inventory of restoration structures at the Savage River restoration site. Structures are numbered 1 to 10 in sequence from upstream to downstream and are labeled correspondingly on Figure 3. Structures 5, 6, and 7 were selected for instrumentation.

\begin{tabular}{|c|l|l|}
\hline Structure & \multicolumn{1}{|c|}{ Type } & \multicolumn{1}{c|}{ Instrumentation } \\
\hline 1 & Log/rock combination J-hook vane & none \\
\hline 2 & Log/rock combination J-hook vane & none \\
\hline 3 & Log/rock combination J-hook vane & none \\
\hline 4 & Log J-hook vane & none \\
\hline 5 & Rock J-hook vane & Peizometers 5A, 5Ab, 5B, 5C, 5Cb, 5D; Dowels Y, $\mathrm{X}$ \\
\hline 6 & Log/rock combination J-hook vane & Peizometers 6A, 6Ab, 6B, 6Bb, 6C, 6D, 6E; Dowels $\mathrm{W}, \mathrm{T} ;$ Stream gage \\
\hline 7 & Log cross-vane & Peizometers 7A, 7Ab, 7B, 7C, 7Cb, 7D, 7E; Dowels V, S \\
\hline 8 & Log J-hook vane & none \\
\hline 9 & Log cross-vane & none \\
\hline 10 & Log/rock combination J-hook vane & none \\
\hline
\end{tabular}

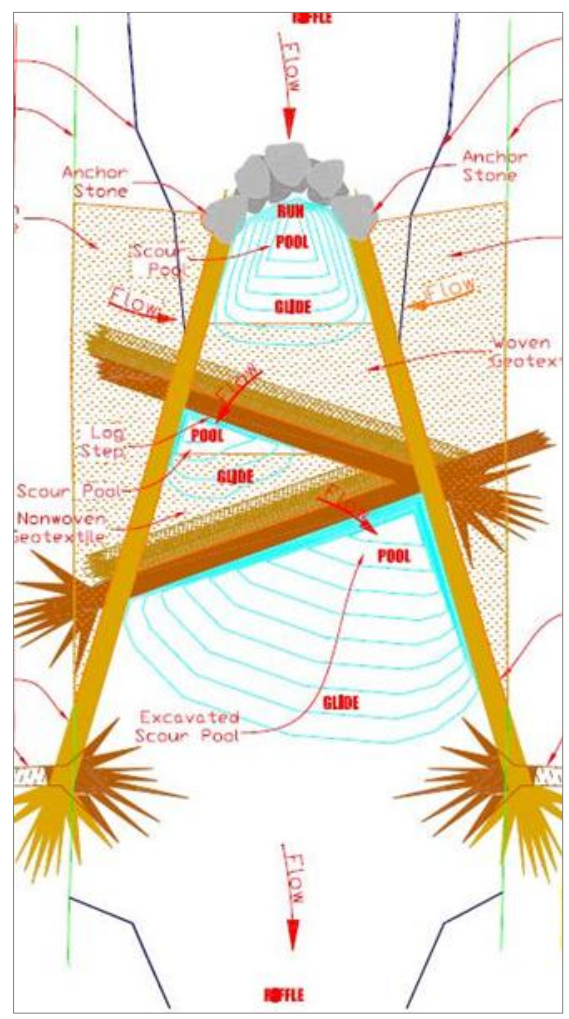

Figure 4: Plan view of log cross-vane design by Postlethwait (2010a). Log cross-vanes were built with two log arms; the cut were ends buried in the streambed and the rooted ends were buried in the banks. Two log crossvanes were installed on the constructed reach.

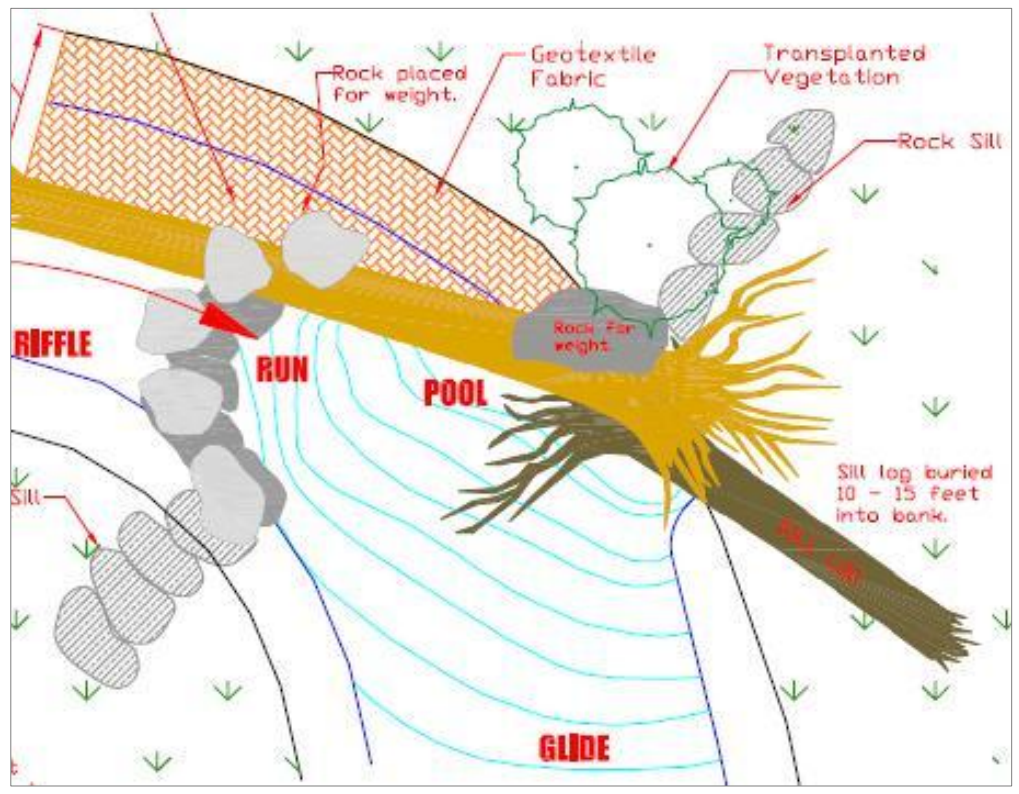

Figure 5: Plan view of log/rock combination J-hook vane design by Postlethwait (2010a). Log/rock combination J-hook vanes were built with one log arm and a 'hook' constructed out of boulders. Five $\log$ /rock combination J-hook vanes were installed on the constructed reach. 
and the opposite bank (Figure 6). Geotextile was placed behind both logs. Rocks were placed on both logs, and a sill log was buried at the rooted end of the log arm. The root wad extended out of the sill log into the excavated scour pool (Postlethwait, 2010a).

The rock J-hook vane was built with one arm at bankfull elevation and a hook installed lower than bankfull (Figure 7). Both the arm and the hook were constructed out of courses of boulders (Postlethwait, 2010a).

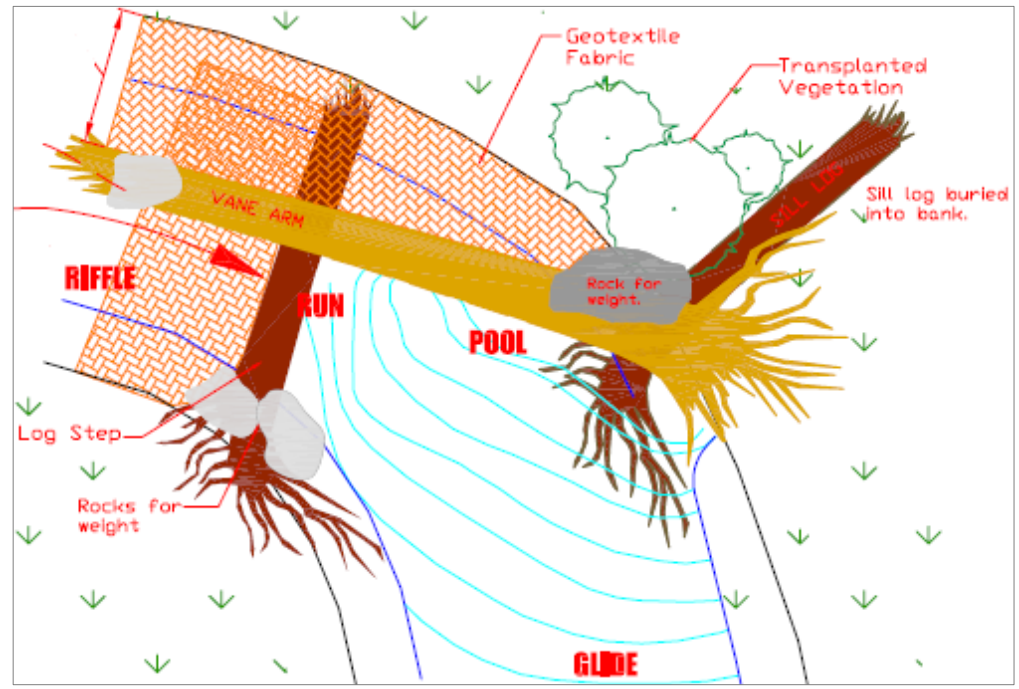

Figure 6: Plan view of log J-hook vane design by Postlethwait (2010a). Log JHook vanes were built with one log arm and a log step. Two log J-hook vanes were installed on the constructed reach.

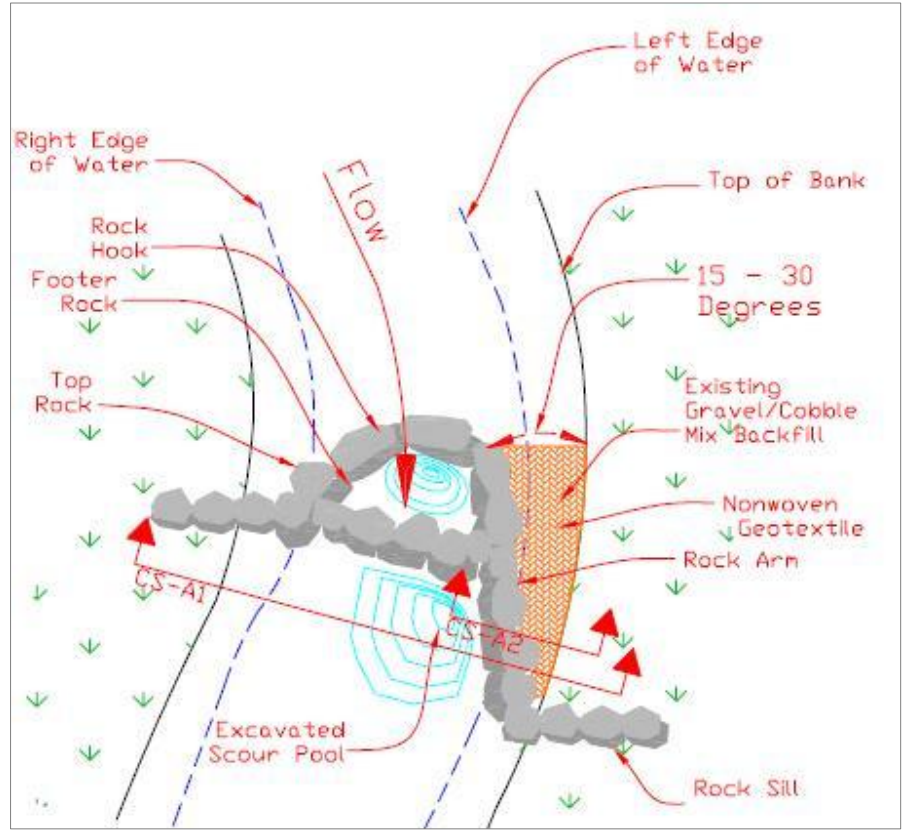

Figure 7: Plan view of rock J-hook vane design by Postlethwait (2010a). The rock J-hook vane was built with one arm and a hook, both constructed out of layers of boulders. One rock J-hook vane was installed on the constructed reach. 


\section{Methods}

\section{Selection of Study Sites}

Three sequential restoration structures were selected for instrumentation and analysis:

1) Structure \#5: rock J-hook vane (Figure 8)

2) Structure \#6: log-rock combination J-hook vane (Figure 9)

3) Structure \#7: log cross-vane (Figure 10)

These structures represented three different structure types with varying hydraulic head changes, so that hyporheic exchange at different structure types could be compared. Structures 1-4 were deliberately not selected due to their proximity to the wetland; a hydraulic connection between the stream and the wetland could potentially overprint hyporheic exchange around those structures. Structures 5-7 were preferable to Structures 8-10 because they provided a wider range in hydraulic head change across the structures.

A reference site was selected downstream of the constructed reach in a natural riffle (Figure 11).

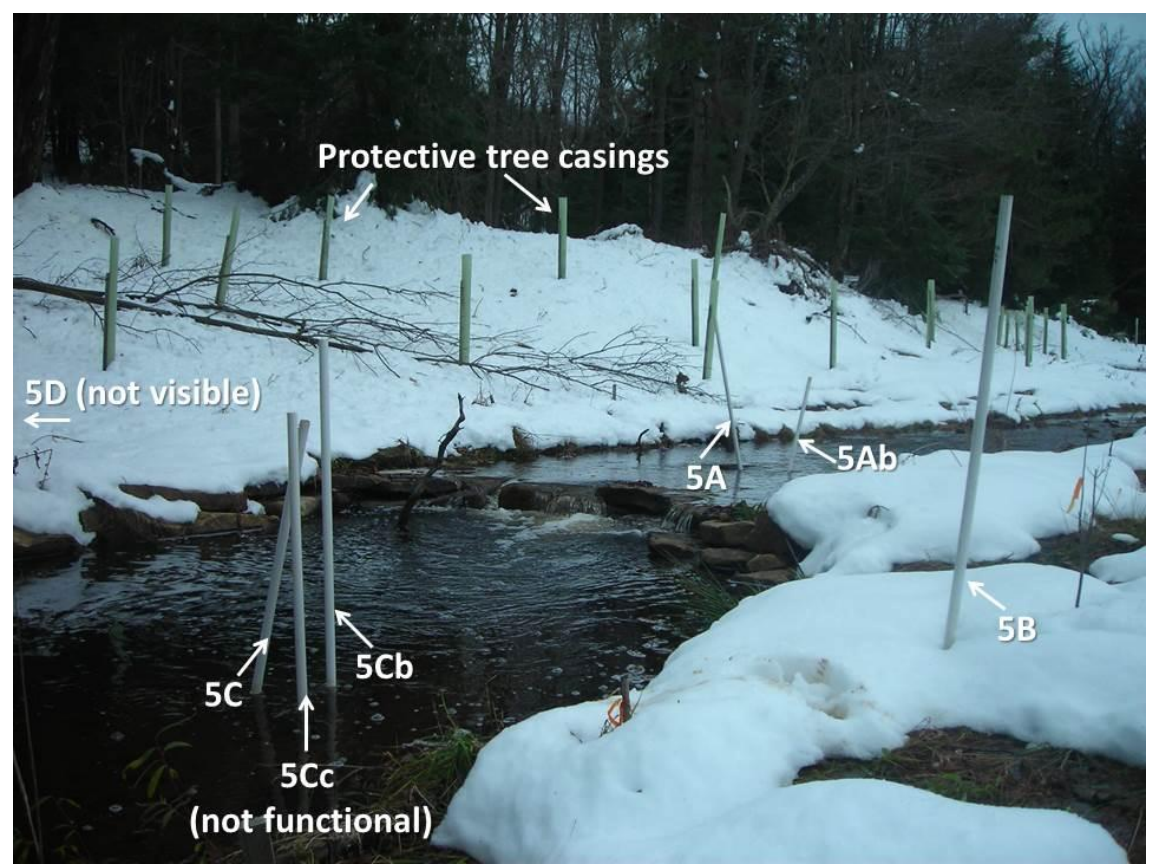

Figure 8: Structure 5, an instrumented rock J-hook vane. Piezometers (labeled) are white PVC pipes installed in the stream banks and streambed. Two iButton dowels ( $\mathrm{Y}$ and $\mathrm{X}$, not pictured) were installed in the stream near piezometers $5 \mathrm{~A} / 5 \mathrm{Ab}$ and $5 \mathrm{C} / 5 \mathrm{Cb}$, respectively. Light green casings are protective casings for tree plantings and were not relevant to the study. 


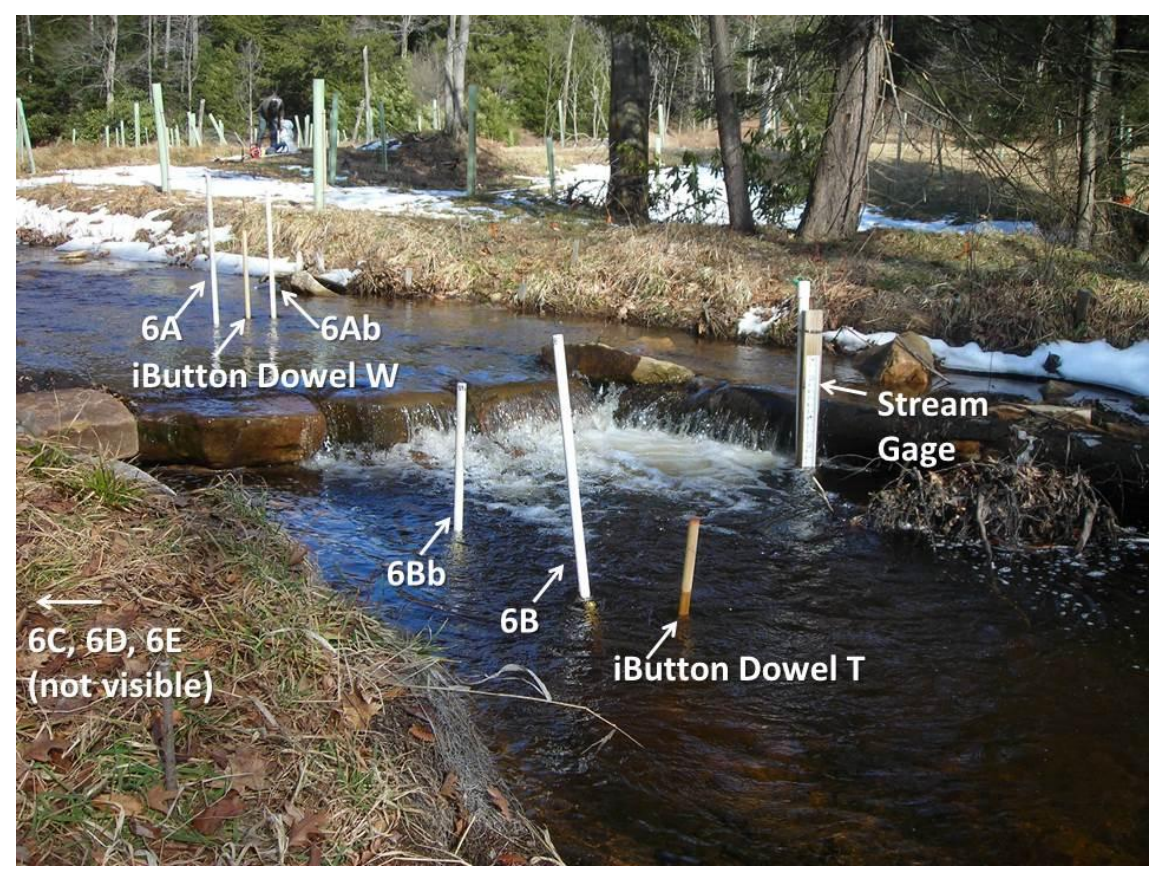

Figure 9: Structure 6, an instrumented log/rock combination J-hook vane. Piezometers (labeled) were installed in the stream banks and streambed. Two iButton dowels ( $\mathrm{W}$ and $\mathrm{T}$ ) were installed in the stream near piezometers $6 \mathrm{~A} / 5 \mathrm{Ab}$ and $6 \mathrm{~B} / 6 \mathrm{Bb}$. The stream gage and staff plate are attached to the log arm of the structure. Light green casings are protective casings for tree plantings and were not relevant to the study.

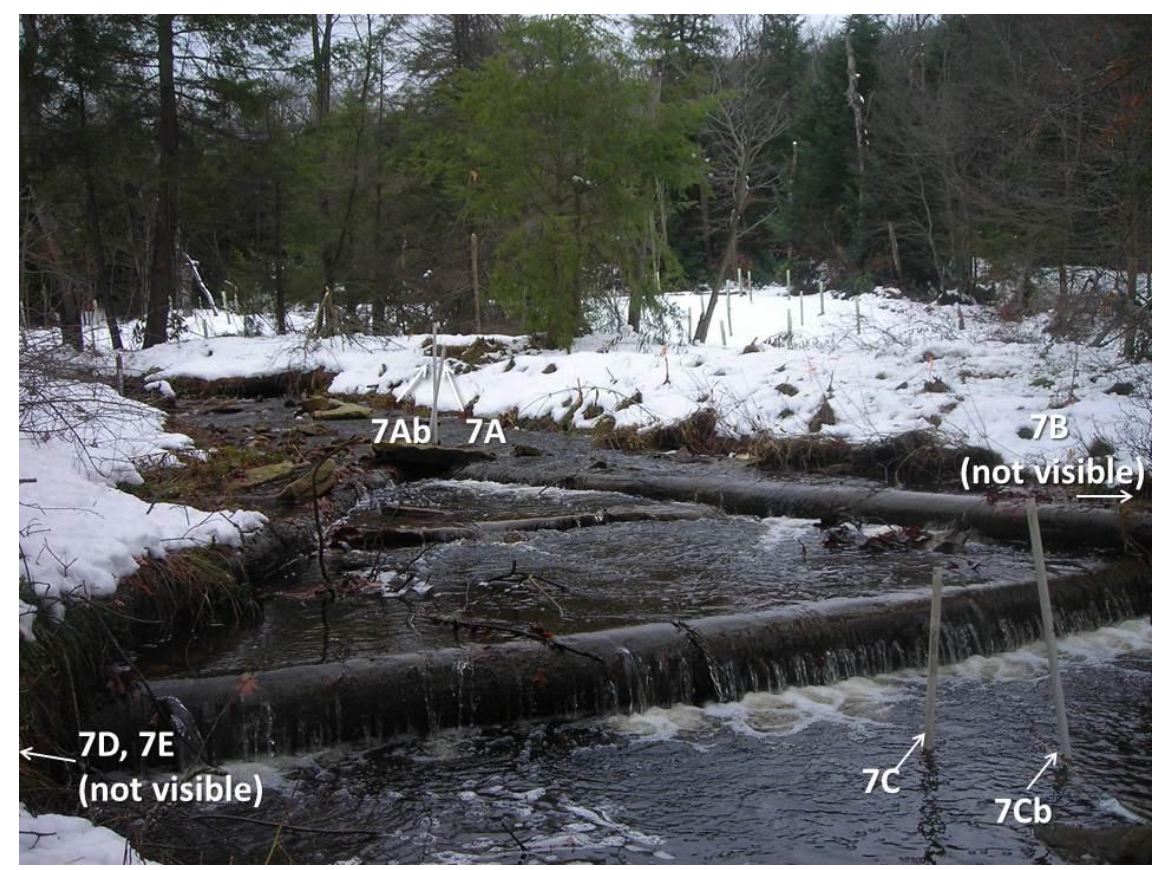

Figure 10: Structure 7, an instrumented log cross-vane. Piezometers (labeled) are white PVC pipes installed in stream banks and streambed. Two iButton dowels ( $\mathrm{V}$ and $\mathrm{S}$, not pictured) were installed in the stream near piezometers $7 \mathrm{~A} / 7 \mathrm{Ab}$ and $7 \mathrm{C} / 7 \mathrm{Cb}$, respectively. Light green casings are protective casings for tree plantings and were not relevant to the study. 


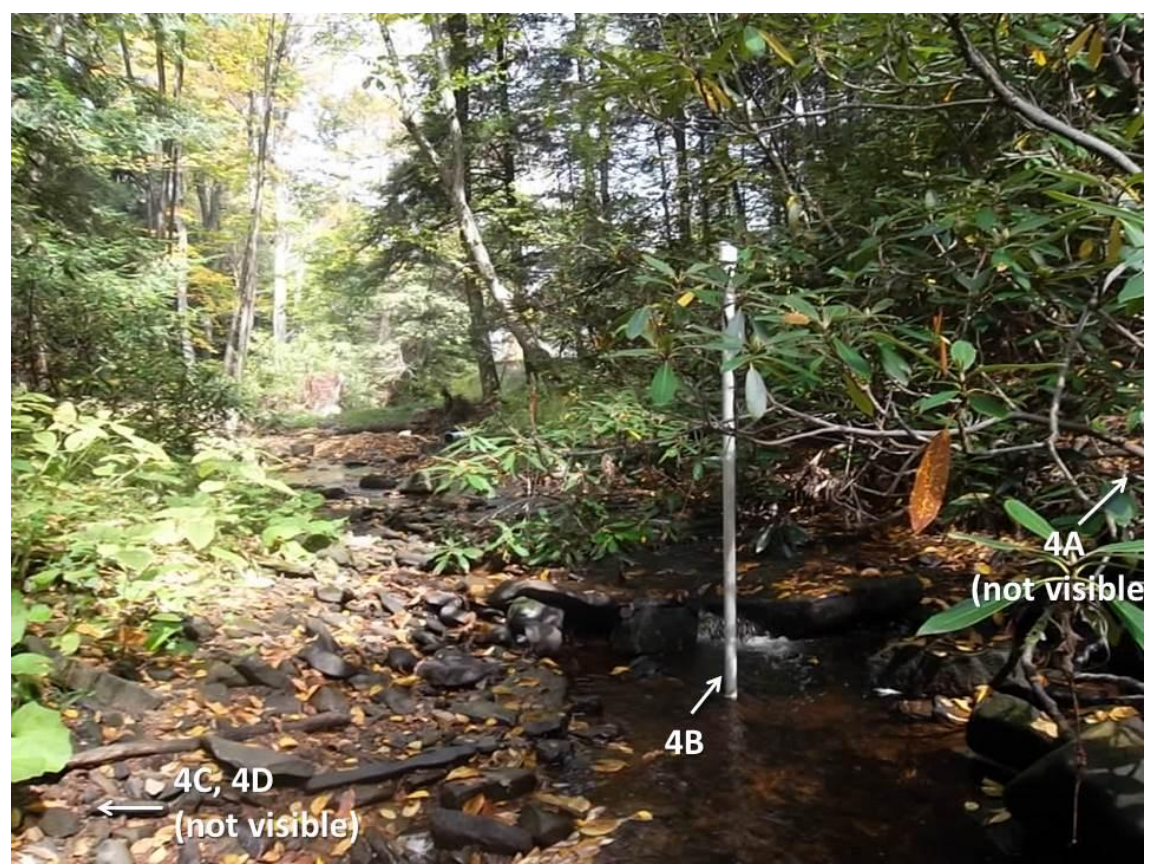

Figure 11: Reference riffle downstream from the constructed channel. Only piezometer $4 \mathrm{~B}$ is visible in this picture; $4 \mathrm{Bb}$ was installed later next to $4 \mathrm{~B}$. The iButton dowel (Z, not pictured) was installed next to $4 \mathrm{~B}$ and $4 \mathrm{Bb}$.

\section{Field Instrumentation}

Piezometer networks were installed at each of the three selected structures and the reference riffle in September 2011 (Figure 12; Table 3). Additional piezometers were installed in the streambed in February 2012, nested with some of the previously installed piezometers. Piezometers consisted of $2.54 \mathrm{~cm}$ (1 in) inner diameter PVC pipe driven into the ground using a fencepost pounder (Figures 8-11). Nine of these piezometers were instrumented with automated pressure transducers/data loggers that measured pressure, depth and temperature (Table 3). To correct the transducer data for changes in ambient barometric pressure, an additional pressure transducer/data logger was installed on a nearby tree. The transducers were programmed to take measurements every 30 minutes for the duration of the study. Water levels were measured manually with a water level tape in all of the piezometers two times during the study period in order to obtain instantaneous measurements of hydraulic head. From September 2011 to February 2012, the locations for pressure transducers provided coverage on both the stream 


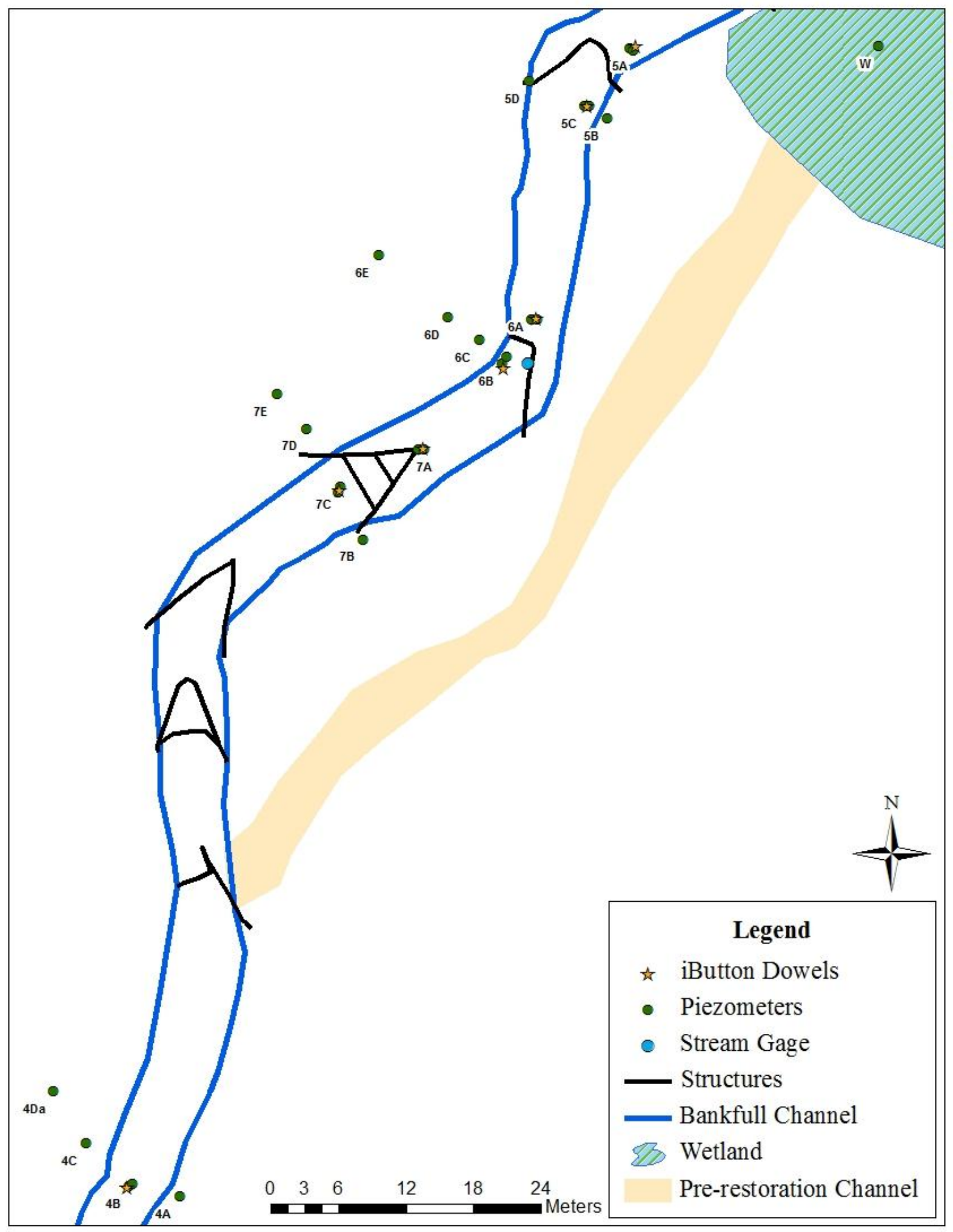

Figure 12: Map of the study site. The restoration structures and constructed bankfull channel were surveyed by Canaan Valley Institute (Postlethwait, 2011); the channel edge was estimated at the reference riffle. Instrument locations were surveyed in this study. Instrumented structures and the reference riffle are shown at a larger scale in Figures 17, 18, and 19. 


\begin{tabular}{|c|c|c|c|c|}
\hline Name & Date Installed & Location & \begin{tabular}{|c|} 
Transducer \\
9/14/2011- \\
2/18/2012
\end{tabular} & $\begin{array}{l}\text { Transducer } \\
2 / 18 / 2012- \\
3 / 31 / 2012\end{array}$ \\
\hline $5 A$ & 9/10/2011 & Upstream of Structure 5 & Yes & Yes \\
\hline $5 A b$ & $2 / 10 / 2012$ & Upstream of Structure 5 & No & Yes \\
\hline $5 B$ & $9 / 10 / 2011$ & Left floodplain Structure 5 & No & No \\
\hline $5 C$ & $9 / 10 / 2011$ & Downstream of Structure 5 & Yes & Yes \\
\hline $5 \mathrm{Cb}$ & $2 / 10 / 2012$ & Downstream of Structure 5 & No & No \\
\hline $5 \mathrm{D}$ & 9/10/2011 & Right floodplain Structure 5 & Yes & No \\
\hline $6 \mathrm{~A}$ & 9/10/2011 & Upstream of Structure 6 & No & No \\
\hline $6 \mathrm{Ab}$ & $2 / 10 / 2012$ & Upstream of Structure 6 & No & No \\
\hline $6 B$ & $9 / 10 / 2011$ & Downstream of Structure 6 & No & No \\
\hline $6 \mathrm{Bb}$ & $2 / 10 / 2012$ & Downstream of Structure 6 & No & No \\
\hline $6 C$ & $9 / 10 / 2011$ & Right floodplain Structure 6 & No & No \\
\hline $6 \mathrm{D}$ & $9 / 10 / 2011$ & Right floodplain Structure 6 & No & No \\
\hline $6 \mathrm{E}$ & 9/10/2011 & Right floodplain Structure 6 & No & No \\
\hline $7 A$ & 9/10/2011 & Upstream of Structure 7 & Yes & Yes \\
\hline $7 A b$ & $2 / 10 / 2012$ & Upstream of Structure 7 & No & Yes \\
\hline 7B & $9 / 10 / 2011$ & Left floodplain Structure 6 & Yes & No \\
\hline 7C & $9 / 10 / 2011$ & Downstream of Structure 7 & Yes & Yes \\
\hline $7 \mathrm{Cb}$ & $2 / 10 / 2012$ & Downstream of Structure 7 & No & Yes \\
\hline $7 \mathrm{D}$ & 9/10/2011 & Right floodplain Structure 7 & Yes & No \\
\hline $7 \mathrm{E}$ & 9/10/2011 & Right floodplain Structure 7 & No & No \\
\hline $4 \mathrm{~A}$ & 9/10/2011 & Left terrace reference riffle & No & No \\
\hline $4 \mathrm{~B}$ & 9/10/2011 & In stream reference riffle & Yes & Yes \\
\hline $4 \mathrm{Bb}$ & $2 / 10 / 2012$ & In stream reference riffle & No & Yes \\
\hline $4 C$ & 9/10/2011 & Right floodplain reference riffle & Yes & No \\
\hline 4Da & 9/10/2011 & Right terrace reference riffle & No & No \\
\hline W & $2 / 10 / 2012$ & Wetland & No & No \\
\hline
\end{tabular}

Table 3: Inventory of piezometers and pressure transducers. Nine pressure transducers logged data during this study; the on-bank pressure transducers were moved to newly installed in-stream piezometers on 18 February 2012 so that vertical hydraulic gradients could be determined in the stream. Piezometer locations are mapped on Figure 12. 
banks and streambed at the reference site and the structures with the greatest head change (\#7) and lowest head change (\#5). In February 2012, some of the pressure transducers were moved from the stream banks to newly-installed piezometers in the streambed in order to measure hydraulic gradients at nested piezometer pairs (Table 3). The discussion below focuses on hydrometric data collected at the same time as thermal data collection, 18 February to 26 March 2012. Hydrometric data from the September 2011 to February 2012 and April 2012 to November 2012 time periods are presented in Appendix A and will not be a focus of the Results or Discussion.

A staff plate and a stream gage were installed in the pool downstream of Structure 6 (Figure 9). The stream gage consisted of slotted PVC pipe with a pressure transducer/data logger suspended inside. Discharge was measured just downstream of the stream gage with a Sontek Flow Tracker 3 times on each of 6 days in order to develop a rating curve (Appendix B).

Temperature time series were collected in vertical profiles at seven locations in the streambed ('iButton Dowels' on Figure 12). Maxim Integrated Thermochron DS1922L iButton temperature data loggers (Figure 13) were embedded in pre-drilled holes on $3.18 \mathrm{~cm}$ (1.25 in) diameter wooden dowels and sealed with silicone sealant and waterproof tape (Figure 14). The silicone provided a waterproof barrier between the dowel and the sides and back of the sensor, and the tape provided additional security to keep the iButtons in place during dowel installation and extraction. A hole was cut in the waterproof tape so that the front of the iButton was in contact with water throughout the study period.

The iButton dowels were installed in the reference riffle and at locations upstream and downstream of each restoration structure (Figures 9, 12). A steel rod similar in diameter to the wooden dowels was driven into the streambed with a fencepost pounder and withdrawn to create 
a guide hole. The dowels were immediately inserted into the guide holes and gently driven to the appropriate depth with the fencepost pounder. Dowels were installed so that one iButton was positioned at the streambed interface $(0 \mathrm{~cm}$ depth) with the others positioned at $5 \mathrm{~cm}$ and $25 \mathrm{~cm}$ depth in the streambed. In this document, iButtons will be referred to by their depth below the streambed: $0 \mathrm{~cm}, 5 \mathrm{~cm}$ and $25 \mathrm{~cm}$. All iButtons were programmed to record temperatures at 15 minute intervals at $0.0625{ }^{\circ} \mathrm{C}$ resolution from 18 February to 26 March 2012 .

Horizontal positions and vertical elevations of piezometers, dowels and the stream gage were surveyed with a Leica TV400 Electronic Total Station and tied to benchmarks installed by Canaan Valley Institute. A longitudinal profile (Figure 15) of the streambed and water surface across the restoration structures was performed with a Leica Rugby laser level.

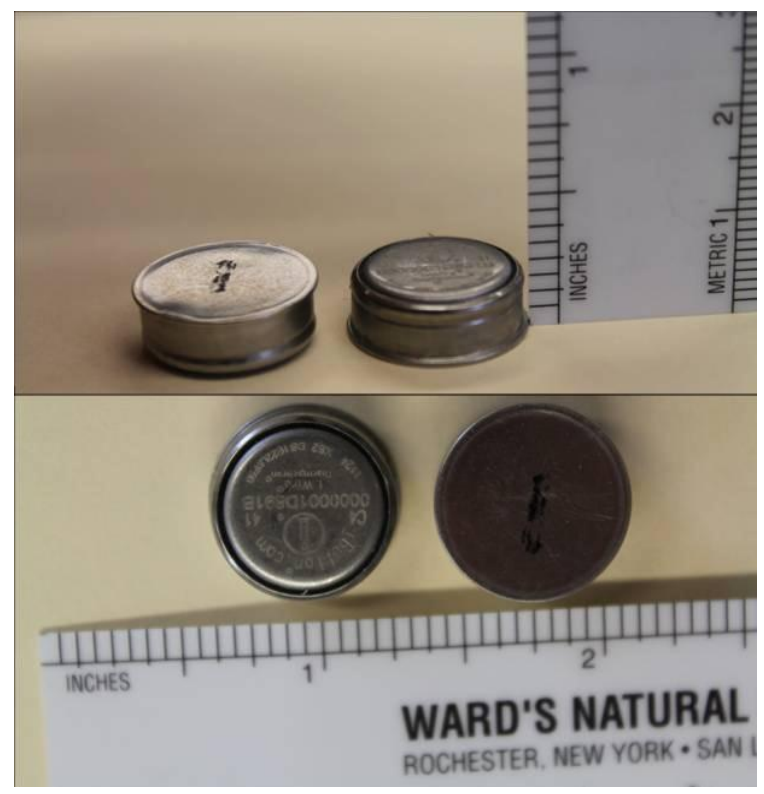

Figure 13: Thermochron iButton model DS1922L. Twenty-one iButtons were attached to wooden dowels and installed in the streambed. They logged temperatures at 15 -minute intervals from 18 February to 26 March, 2012

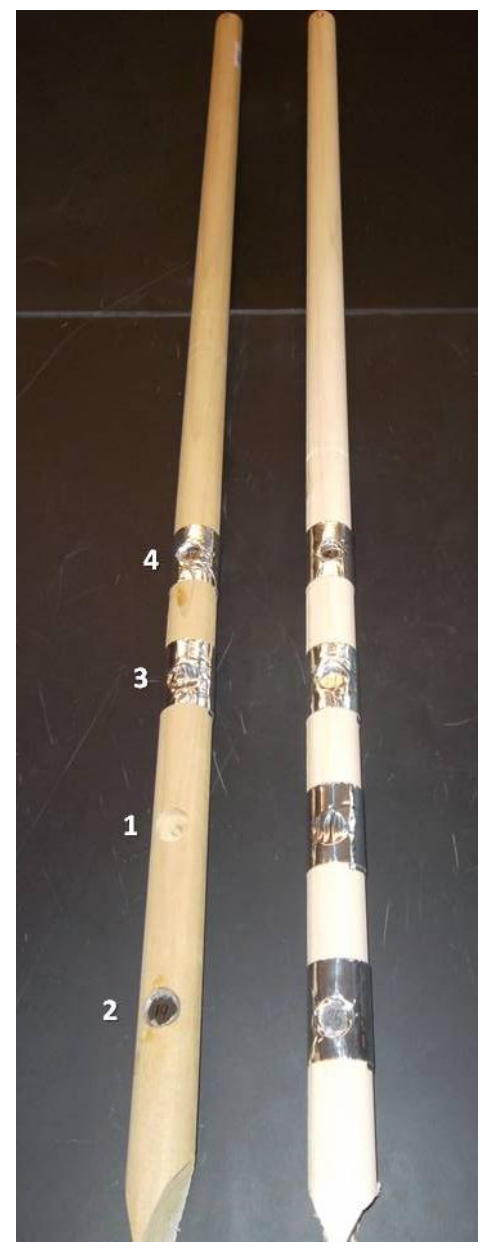

Figure 14: iButton dowel construction. The left dowel shows each stage of construction. 1) Hole drilled in 3.18 $\mathrm{cm}$ diameter wooden dowel (second from bottom), 2) iButton sealed in the hole (bottom), 3) iButton covered with waterproof tape (second from top), 4) Hole cut in waterproof tape to expose the face of the iButton (top). The dowel on the right shows a complete dowel construction. Four holes were drilled on each dowel, but iButtons were installed in only three holes. 


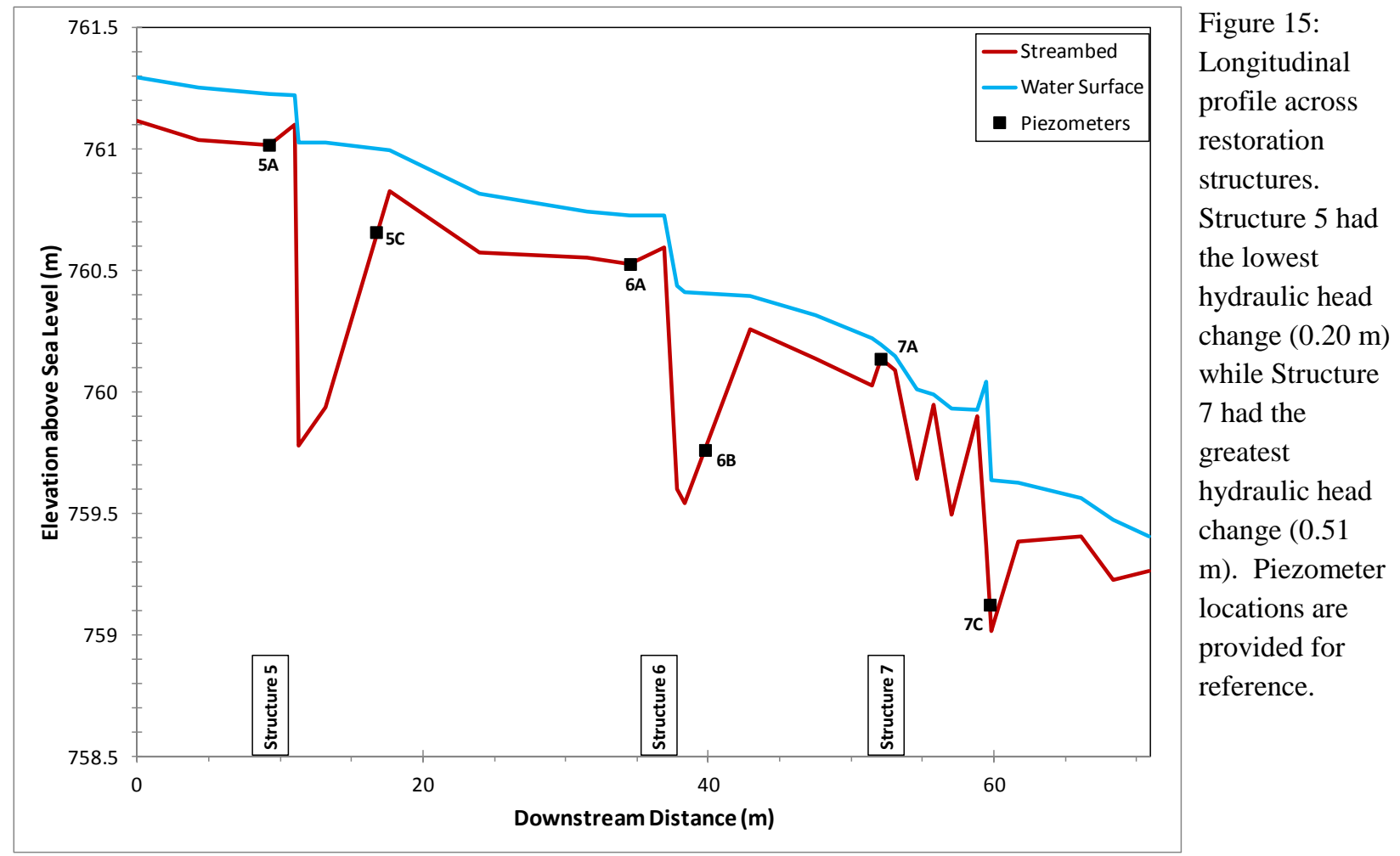

\section{Heat Transport Modeling}

The heat transport model described by Hatch et al. (2006) was used to calculate vertical volumetric flux rates between pairs of iButtons on each dowel. This model is an analytical solution to the one-dimensional conduction-advection-dispersion equation presented by Stallman (1965):

$$
\frac{\delta T}{\delta t}=\kappa_{e} \frac{\delta^{2} T}{\delta z^{2}}-q \frac{C_{w}}{C} \frac{\delta T}{\delta z}
$$

where $T$ is temperature, $z$ is depth in the streambed, $q$ is fluid flux, $C_{w}$ is the volumetric heat capacity of the water, $C$ is the volumetric heat capacity of the saturated streambed and $\kappa_{e}$ is effective thermal diffusivity of the saturated sediment (Stallman, 1965; Hatch et al., 2006; 
Gordon et al., 2012). Thermal diffusivity is given by:

$$
\kappa_{e}=\left(\frac{\lambda_{0}}{C}\right)+\beta\left|\frac{q}{n_{e}}\right|
$$

where $\lambda_{0}$ is thermal conductivity of the saturated sediment, $\beta$ is thermal dispersivity, and $n_{e}$ is the effective porosity (Stallman, 1965; Hatch et al., 2006; Gordon et al., 2012).

Stallman (1965) showed that water flux rates can be determined by analyzing sinusoidal fluctuations of temperature at depth in the subsurface. Diurnal heating and cooling of the stream water generates a quasi-sinusoidal temperature signal in the streambed by conduction of heat between individual particles and by advection of heat when water flows through the streambed (Daniluk et al., 2012). This diurnal signal attenuates with depth into the streambed, and Hatch et al. (2006) solved Equation 1 for $q$ as a function of the ratio of diurnal signal amplitudes at two depths in the subsurface:

$$
\begin{gathered}
q=\frac{C}{C_{w}}\left(\frac{2 \kappa_{e}}{\Delta z} \ln A_{r}+\sqrt{\frac{\alpha}{2}}\right) \\
\alpha=\left(q \frac{C_{w}}{C}\right)^{2}+\sqrt{\left(q \frac{C_{w}}{C}\right)^{4}+\left(\frac{8 \pi \kappa_{e}}{P}\right)^{2}}
\end{gathered}
$$

where $q$ is the vertical volumetric fluid flux in the downward direction, $A_{r}$ is the ratio of amplitudes between the lower sensor and the upper sensor, $\Delta z$ is the distance between the two sensors and $P$ is the period of the temperature signals. When iButtons are installed in the streambed in a vertically stacked array, the Hatch et al. (2006) model calculates the vertical flux 
between two iButtons based on the ratio of the amplitudes of the diurnal signals recorded by the iButtons.

Stallman (1965) stated several simplifying assumptions upon which the Hatch et al. (2006) model is based:

1) Heat and fluid flow occur only in the vertical direction (parallel to the axis of the iButton array).

2) Thermal characteristics of the streambed and fluid are constant in both time and space.

3) The fluid and streambed are at thermal equilibrium.

4) Temperature fluctuations in the streambed are in equilibrium with fluctuations in the stream.

A computer program developed by Gordon et al. (2012) entitled VFLUX (Vertical Fluid [Heat] Transport Solver) was used to analyze the temperature time series and implement the Hatch et al. (2006) model. VFLUX is a MATLAB-based program that formats and resamples temperature time series, isolates the diurnal temperature signal, extracts the amplitude of the diurnal signal, and calculates vertical water flux rates between two temperature sensors every 2 hours (Gordon et al., 2012). It requires the user to input thermal properties and to select the desired combinations of sensor pairs for flux calculations. The program uses Dynamic Harmonic Regression, as implemented by the MATLAB Captain Toolbox, to isolate the fundamental temperature signal from the signal's trend, noise and harmonics (Young, 2010; Gordon et al., 2012). A more detailed discussion of the VFLUX program is provided by Gordon et al. (2012).

In this study, VFLUX was run using the thermal parameters presented in Table 4 for all three possible pairs of iButtons on each dowel: $0 \mathrm{~cm}$ and $5 \mathrm{~cm}$ (shallow pair), $5 \mathrm{~cm}$ and $25 \mathrm{~cm}$ (deep pair), and $0 \mathrm{~cm}$ and $25 \mathrm{~cm}$. Thermal parameters were estimated based on a literature 
review, including several studies utilizing the Hatch et al. (2006) model (Lapham, 1989; Kresic, 1997; Bunte and Abt, 2001; Stonestrom and Blasch, 2003; Stonestrom and Constantz, 2003;

Hatch et al., 2006; Crispell and Endreny, 2009; Lautz et al., 2010; Shanafield et al., 2011; Briggs et al., 2012; Daniluk et al., 2012; Gordon et al., 2012; Gordon et al., in press). As recommended by previous studies, the first three and last three days of flux calculations were removed from each dataset to eliminate edge effects induced by the digital filtering (Hatch et al., 2006; Gordon et al., 2012). Monte Carlo error analyses were performed in VFLUX to estimate error due to uncertainty in the sediment thermal parameters.

Table 4: Thermal and hydraulic parameters used in the heat transport model. Values and standard deviations were estimated based on a literature review (see references in text).

\begin{tabular}{|c|c|r|r|c|}
\hline Symbol & Parameter & Value & Standard Deviation & Units \\
\hline $\boldsymbol{n}_{\boldsymbol{e}}$ & Porosity & 0.2 & 0.05 & $\mathrm{n} / \mathrm{a}$ \\
\hline $\boldsymbol{\beta}$ & Thermal dispersivity & 0.001 & 0.0001 & $\mathrm{~m}$ \\
\hline $\boldsymbol{\lambda}$ & Thermal conductivity & 0.0054 & 0.0007 & $\mathrm{cal} /\left(\mathrm{s}^{*} \mathrm{~cm}^{*^{\circ}} \mathrm{C}\right)$ \\
\hline $\boldsymbol{C}$ & Heat capacity of sediment & 0.5 & 0.02 & $\mathrm{cal} /\left(\mathrm{cm}^{3{ }^{\circ}} \mathrm{C}\right)$ \\
\hline $\boldsymbol{C}_{\boldsymbol{w}}$ & Heat capacity of water & 1 & 0.005 & $\mathrm{cal} /\left(\mathrm{cm}^{3 *^{\circ}} \mathrm{C}\right)$ \\
\hline
\end{tabular}

\section{Results}

Hydrometric Data (21 February - 22 March 2012)

Hydrometric data were collected from 14 September 2011 to 3 November 2012, but the discussion below focuses only on the date range corresponding to heat transport modeling results: 21 February to 22 March 2012. Additional hydrometric data are presented in Appendix A. 


\section{Stream Stage and Precipitation}

Precipitation rate data were downloaded from the Maryland Department of Transportation (MDOT) weather archives for a weather station at I-68 on Savage Mountain, 0.8 $\mathrm{km}(0.5 \mathrm{mi})$ from the study site. Precipitation rate was converted to total precipitation amount by calculating the time step between each measurement and multiplying the time step by the rate. The precipitation data (Figure 16) showed several precipitation events during the study period, for which the total event precipitation and event duration are presented in Table 5. The MDOT records also indicated the precipitation type and intensity recorded by the weather station, so the dominant type reported during each event is also presented in Table 5.

Stream stage responded to each event, with the largest stage response associated with the largest event on 29 February, which could have been, in part, a rain-on-snow event. It was noted that no snow cover remained during a field visit on 1 March, after snow cover was observed during the previous visit on 18 February.

Stream stage did not noticeably respond to precipitation recorded on 4 March and 5 March. The records from the MDOT weather station indicated a dominant precipitation type of "slight snow" during these two events. The snow may not have noticeably contributed to stream stage since the total precipitation amount was relatively low and the total amount falling directly on the stream was even lower. Air temperatures remained below freezing on these dates, so snow that fell on the banks may have accumulated rather than melting and entering the stream.

Stream stage suggested a precipitation event on 18 March that was not reflected in the precipitation data. Upon inspection of the MDOT records, "slight rain" was detected by the weather station but no rates were recorded, so no accumulation was calculated for this time period. 


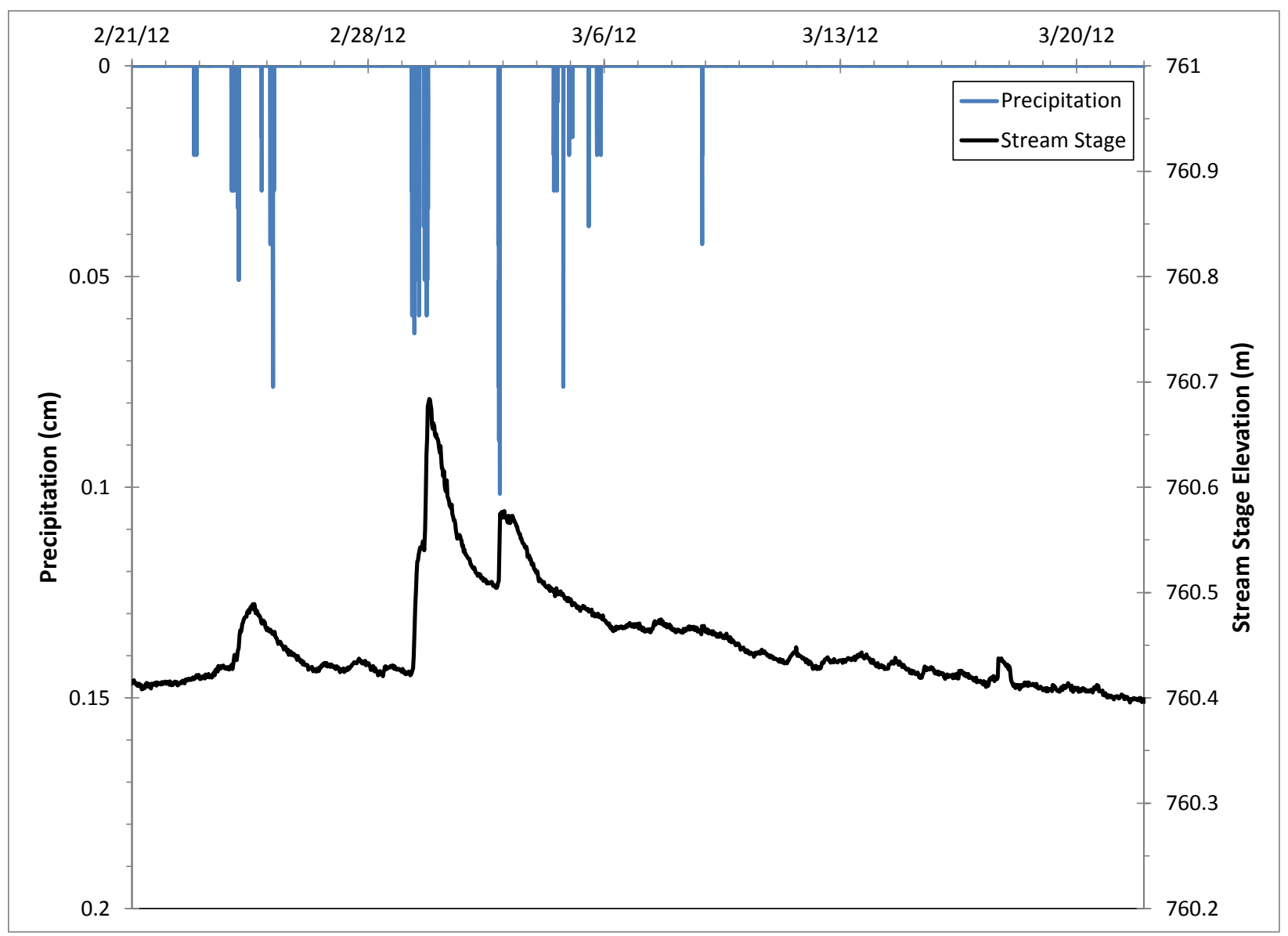

Figure 16: Precipitation amount and stream stage for 21 February through 22 March 2012. Stream stage was collected by a pressure transducer installed on Structure 6 and converted to elevation above sea level. Precipitation data were obtained from a Maryland Department of Transportation (MDOT) weather station located on Savage Mountain. Table 5 summarizes the storms during the study period, most of which were reflected in the stream stage data.

Table 5: Precipitation events during the study period. 'Precipitation' is the total amount detected over the duration of the event; precipitation amount and type are derived from the MDOT weather station. When precipitation type varied over the course of a storm, the dominant type or a range of intensity is reported here.

\begin{tabular}{|r|r|r|l|}
\hline \multicolumn{1}{|c|}{ Date } & Duration (hours) & Precipitation $\mathbf{( c m )}$ & Precipitation Type \\
\hline $2 / 22 / 2012$ & 0.2 & 0.04 & Slight rain \\
\hline $2 / 23-24 / 2012$ & 5.5 & 0.49 & Slight rain \\
\hline $2 / 24-25 / 2012$ & 8.8 & 0.39 & Slight to moderate snow \\
\hline $2 / 29 / 2012$ & 11.8 & 2.17 & Moderate to heavy rain \\
\hline $3 / 2 / 2012$ & 1.2 & 0.68 & Moderate rain \\
\hline $3 / 4 / 2012$ & 13.5 & 0.25 & Intermittent slight snow \\
\hline $3 / 5 / 2012$ & 8.8 & 0.13 & Intermittent slight snow \\
\hline $3 / 8 / 2012$ & 0.3 & 0.84 & Slight rain \\
\hline
\end{tabular}




\section{Structure 5 Piezometer Fluctuations and Stream Stage}

Pressures recorded by the pressure transducers were converted to hydraulic head elevations for each piezometer (Figures 17, 18 and 19). Assuming a constant water surface slope, stream stage data (collected at Structure 6) were extrapolated to the pool downstream of Structure 5 by adding the difference in pool water surface elevations $(0.61 \mathrm{~m} ; 2.0 \mathrm{ft})$, surveyed in the longitudinal profile, to the stream stage data. The extrapolated stage data allowed for comparison between stream stage and hydraulic head in piezometer 5C (Figure 17b).

Piezometers $5 \mathrm{~A}$ and $5 \mathrm{Ab}$ were installed in a riffle upstream of Structure 5 in a nested configuration (Figure 17a); piezometer 5A was installed $0.43 \mathrm{~m}(1.4 \mathrm{ft})$ higher in elevation than $5 \mathrm{Ab}$, allowing for determination of the vertical hydraulic gradient between the two piezometers. The water level in piezometer $5 \mathrm{~A}$ responded to precipitation events and changes in stream stage (Figure 17b). Hydraulic head in piezometer $5 \mathrm{Ab}$ rose slowly and steadily for most of the study period; the signal did not exhibit a pattern similar to stream stage or piezometer 5A. Although there was an increase in water level during the 29 February event, the recession was dampened by the overall trend of increasing hydraulic head. Four piezometers, including $5 \mathrm{Ab}$, exhibited a period of slowly increasing hydraulic head after installation, likely reflecting gradual stabilization of the system following the disturbance of the subsurface (4Bb, Figure 19; 5A, Appendix A; 4B, Appendix A). During the stabilization period, blockages of fine-grained material slowly cleared out of the pipe; this process took only a few days for the other piezometers, but $5 \mathrm{Ab}$ appears not to have fully stabilized during the entire study. Although subsequent transducer data (Appendix A) revealed that the hydrometric signal started responding to stream stage on 24 March, just after the end of the iButton study period, hydrometric data from $5 \mathrm{Ab}$ were not used in this analysis. 


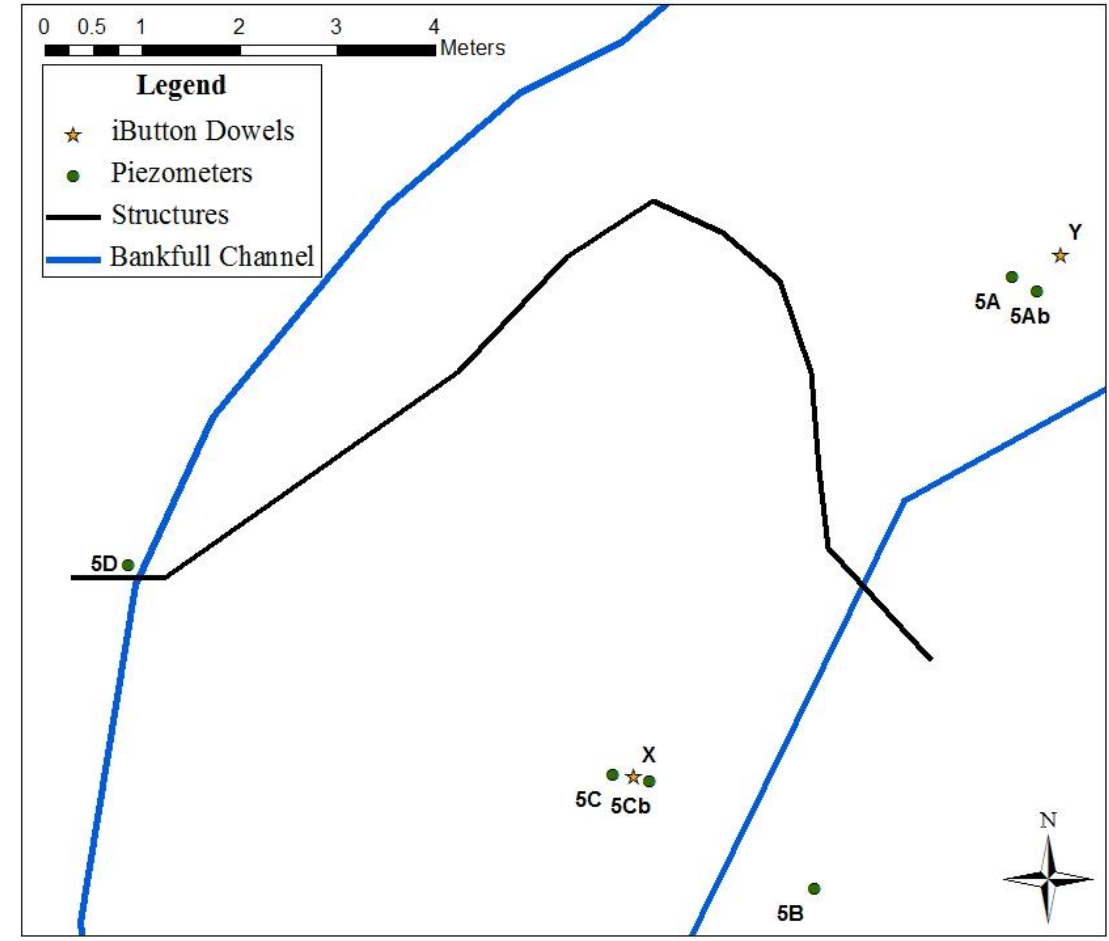

Figure 17a: Instrumentation at Structure 5. Nested pairs of piezometers and iButton dowels $(\mathrm{Y}, \mathrm{X})$ were installed upstream and downstream of the structure, and single piezometers were installed on the stream banks.

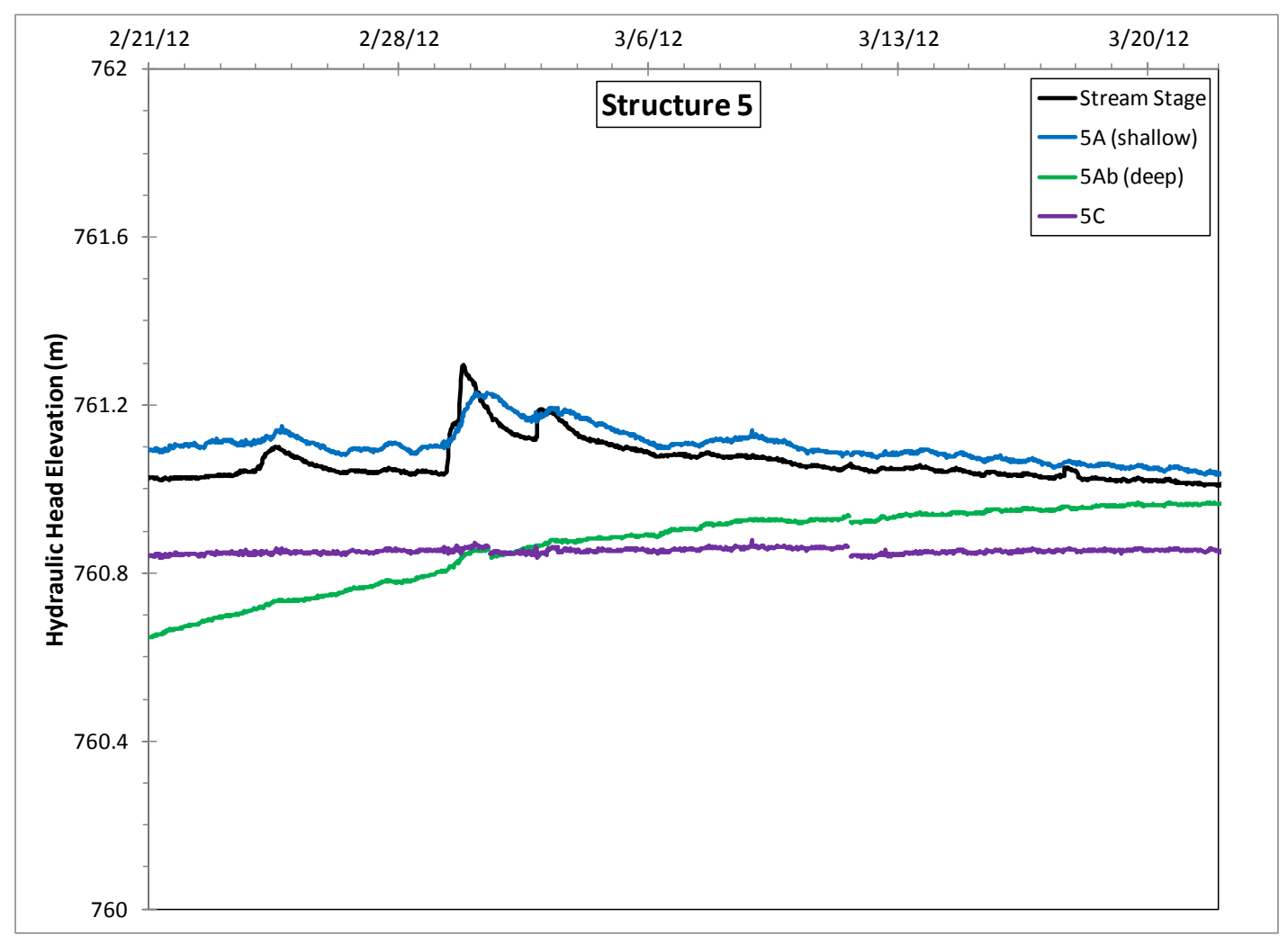

Figure 17b: Hydrometric data from Structure 5. Stream stage was collected at Structure 6 and extrapolated to Structure 5 using water level differences from the longitudinal profile. 
Piezometer 5C was installed downstream of Structure 5 in a sandbar deposited by the stream after construction. The hydrometric signal was static during the iButton study period. Transducer data from before and after the study period (Appendix A) revealed that the hydrometric signal exhibited seasonal head changes over the course of a year, but never responded to individual flow events.

\section{Structure 7 Piezometer Fluctuations and Stream Stage}

Stream stage data (collected at Structure 6) were extrapolated to the pool downstream of Structure 7 using the pool elevations surveyed in the longitudinal profile. Assuming a constant water surface slope, the difference in pool water surface elevations $(0.77 \mathrm{~m} ; 2.5 \mathrm{ft})$ was subtracted from the stream stage data. The extrapolated stage data allowed for comparison between stream stage and hydraulic head in piezometers 7C and 7Cb (Figure 18b).

Piezometers 7A and 7Ab were installed at the upstream end of Structure 7 in a nested configuration (Figure 18a), allowing for determination of the vertical hydraulic gradient between the two piezometers; piezometer 7Ab was installed $0.20 \mathrm{~m}(0.66 \mathrm{ft})$ higher in elevation than 7A. Both 7A and 7Ab were dry for a large portion of the study period (Figure 18b). Piezometer 7A responded to the 24 February event, and both 7A and 7Ab responded dramatically to the 29 February event, showing fluctuations in hydraulic head larger in magnitude than corresponding changes in stream stage. Despite their nested configuration, hydraulic heads in 7A and 7Ab were nearly identical during the flow event, so no hydraulic gradient was discerned.

Piezometers 7C and 7Cb were installed in the plunge pool downstream of Structure 7 (Figure 18a); piezometer 7Cb was installed $0.32 \mathrm{~m}(1.1 \mathrm{ft})$ higher in elevation than $7 \mathrm{C}$. Piezometer 7Cb was dry for about half of the study period, but 7C was never dry. Both 


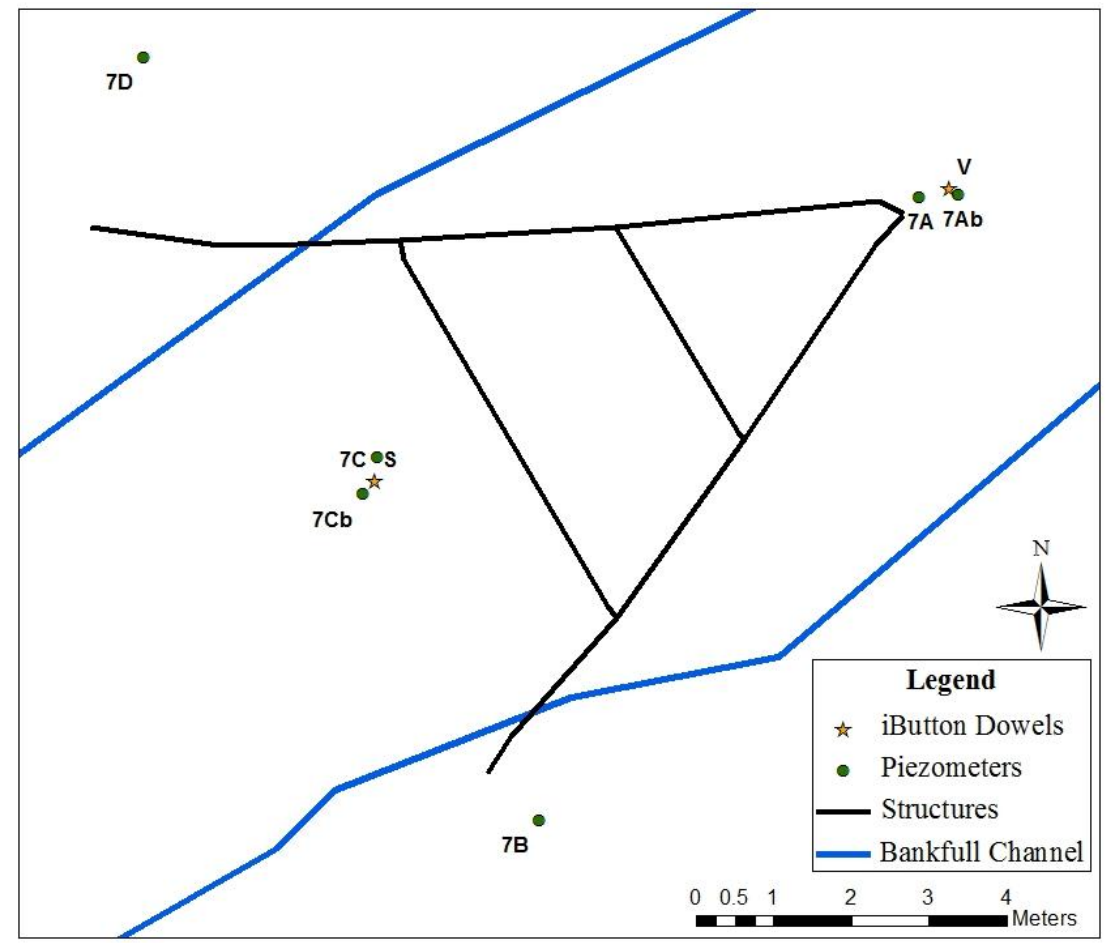

Figure 18a: Instrumentation at Structure 7. Nested pairs of piezometers and iButton dowels $(\mathrm{V}, \mathrm{S})$ were installed upstream and downstream of the structure. Single piezometers were also installed on both stream banks.

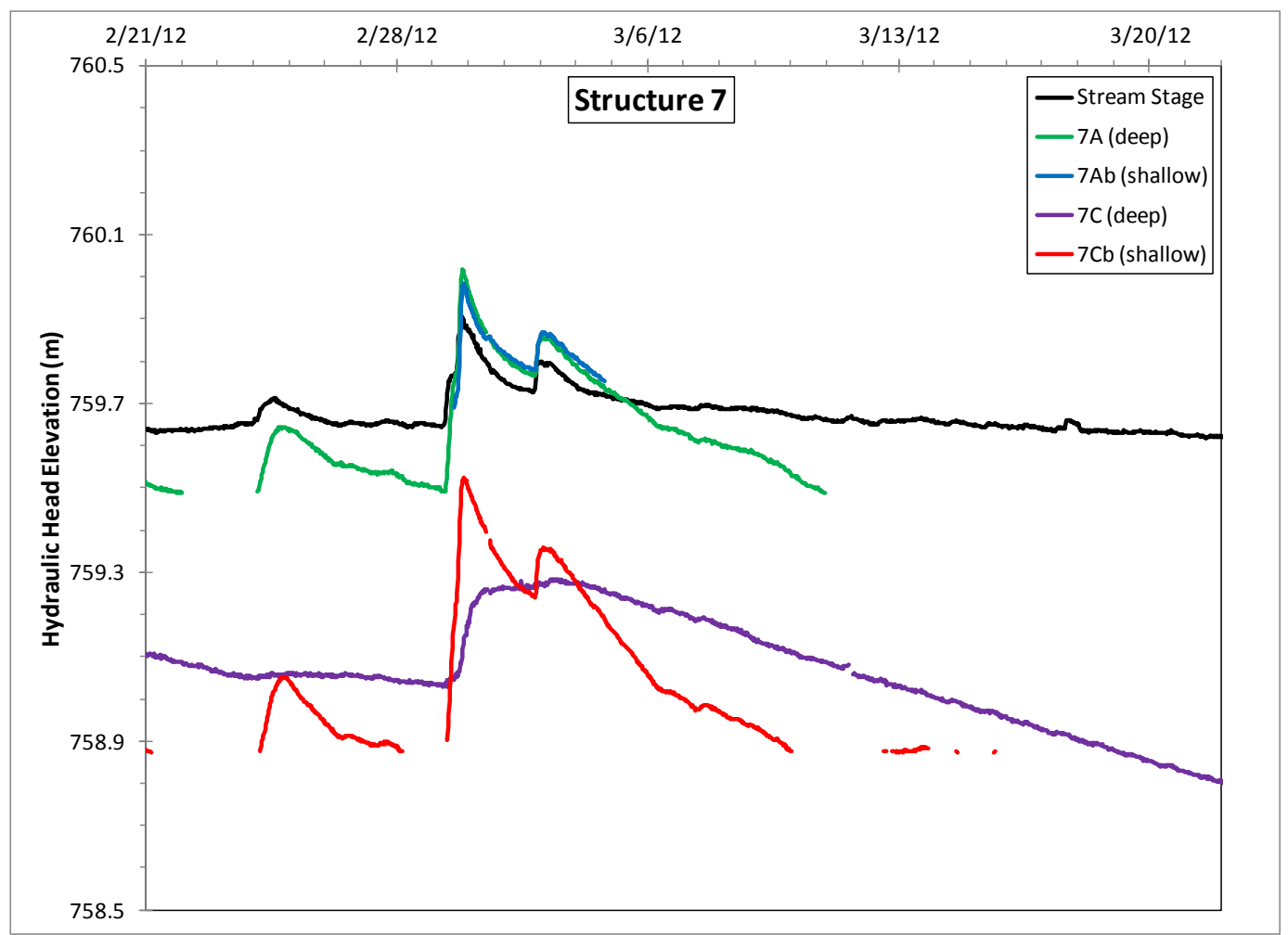

Figure 18b: Hydrometric data from Structure 7. Stream stage was collected at Structure 6 and extrapolated to Structure 7 using the water level differences in the longitudinal profile. The gaps in data for $7 \mathrm{~A}, 7 \mathrm{Ab}$ and $7 \mathrm{Cb}$ indicate that these piezometers were dry during these time periods. 
responded dramatically to the 29 February and 2 March precipitation events, although 7C's response was subdued in comparison to 7Cb's (Figure 18b). Piezometer 7C exhibited a slow, steady decline in hydraulic head following the major precipitation event through the remainder of the study period, while 7Cb fell more quickly, tracking a pattern similar to 7A until 7Cb went dry.

\section{Reference Riffle Piezometer Fluctuations and Stream Stage}

Two piezometers were installed at the reference riffle in a nested configuration (Figure 19a); piezometer $4 \mathrm{Bb}$ was installed $0.26 \mathrm{~m}(0.84 \mathrm{ft})$ higher in elevation than $4 \mathrm{~B}$, allowing for determination of the vertical hydraulic gradient between the two piezometers. Compared to piezometers at the restoration structures, both $4 \mathrm{~B}$ and $4 \mathrm{Bb}$ showed very little variation in hydraulic head (Figure 19b). However, some patterns are evident.

Piezometer $4 \mathrm{Bb}$ was installed shortly before the study period and exhibited a slow, steady rise in hydraulic head for the first four days. This pattern likely reflects a gradual stabilization of the system post-installation, similar to that discussed for $5 \mathrm{Ab}$. Piezometer $4 \mathrm{Bb}$ showed a rapid rise during the 29 February precipitation event and maintained an elevated water level for about five days, before slowly and steadily declining.

Piezometer 4B exhibited a small response to the flows on 24 February and a greater response to the 29 February flow. From 29 February to 5 March, heads in 4B and 4Bb tracked very closely to one another, with $4 \mathrm{Bb}$ slightly higher in elevation than $4 \mathrm{~B}$. Piezometer $4 \mathrm{~B}$ remained elevated until it erratically declined on 9 March, rose on 10 March and again began to decline slowly on 11 March. 


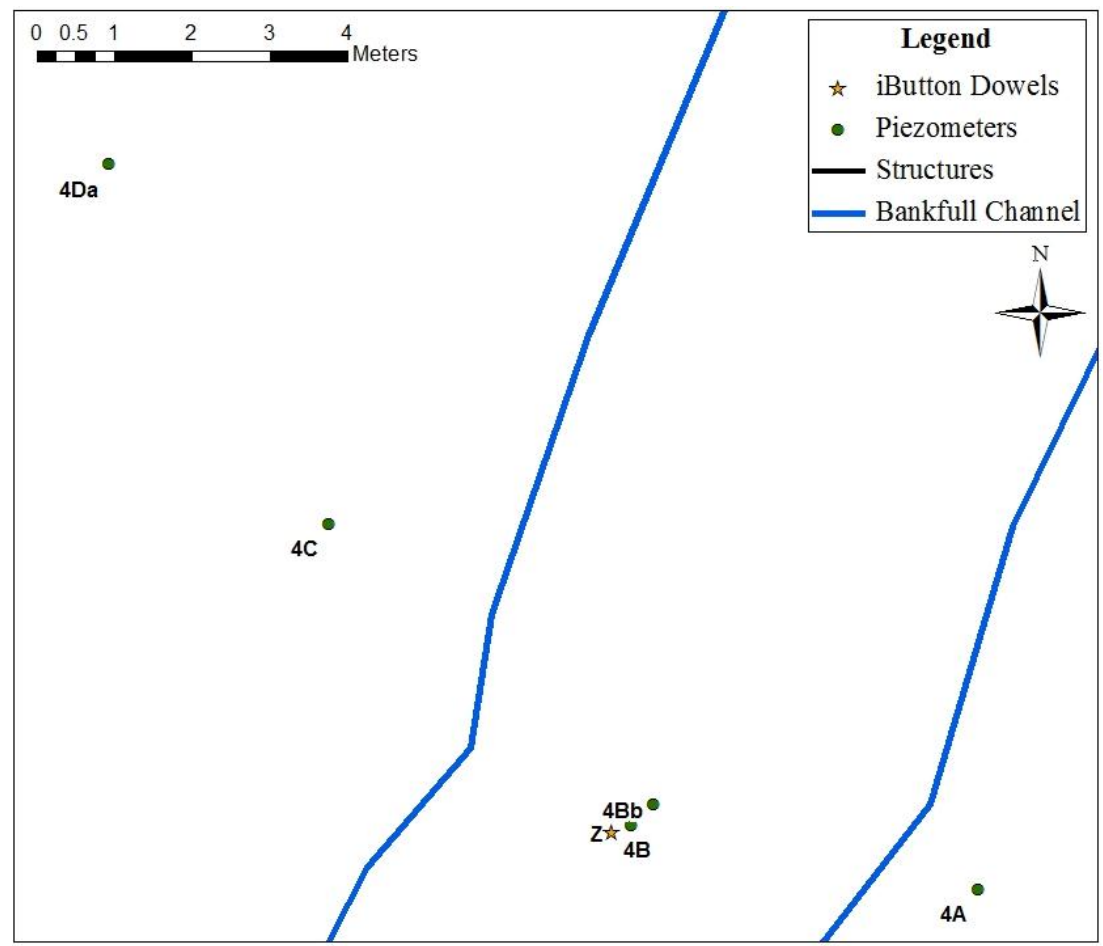

Figure 19a: Instrumentation at the reference riffle. A nested pair of piezometers and an iButton dowel $(Z)$ were installed in the stream channel, and single piezometers were installed on the stream banks.

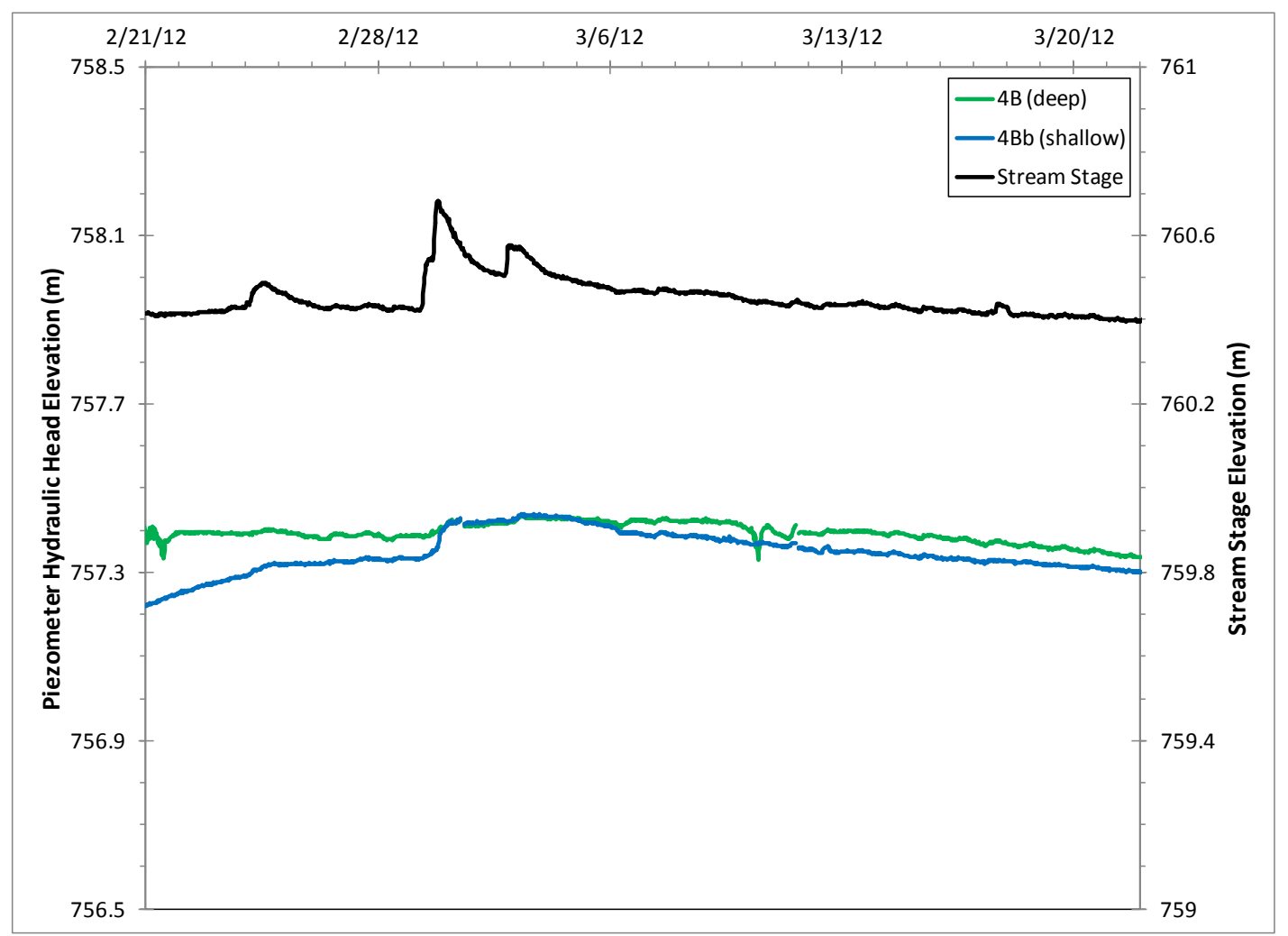

Figure 19b: Hydrometric data from the reference riffle. Stream stage (right axis) was collected at Structure 6. Piezometer 4Bb may have been plugged early in the study period. 


\section{Hydraulic Gradients from Piezometer Data}

Piezometers $7 \mathrm{C} / 7 \mathrm{Cb}$ and $4 \mathrm{~B} / 4 \mathrm{Bb}$ were the only nested pairs from which hydraulic gradients could be established. At other nested pairs, hydrometric signals were too similar (7A/7Ab) or flawed (5Ab, 5C; see discussion in "Hydraulic Connections between the Constructed Stream and the Subsurface"), or transducers were not installed during the study period $(5 \mathrm{Cb}, 6 \mathrm{~A} / 6 \mathrm{Ab}, 6 \mathrm{~B} / 6 \mathrm{Bb})$. Hydraulic gradients determined from manual water level measurements on 2 March and 11 March 2012 are given in Appendix C.

At $7 \mathrm{C}$ and $7 \mathrm{Cb}$, the hydrometric signals indicated upwelling during the 24 February event (Figure 20). Piezometer 7Cb's level rose almost to the same elevation as 7C but actually peaked $0.002 \mathrm{~m}(0.008 \mathrm{ft})$ below $7 \mathrm{C}$, so there was no reversal in gradient direction. There was a gradient reversal during the 29 February flow event, with upwelling early in the event and downwelling from 12:30 pm on 29 February through 11:30 am on 2 March. Upwelling lasted from 12:00 pm on 2 March until the start of the next flow event at 9:30 pm that same evening, then downwelling occurred from 10:00 pm on 2 March through 1:30 am on 4 March. Thus, upwelling occurred during dry conditions and downwelling was induced by rises in stream stage above a threshold of approximately $760.5 \mathrm{~m}$ (Figure 20; stage extrapolates to approximately 759.8 at Structure 7, Figure 18); this threshold was not reached during the 24 February event.

For most of the study period at the reference riffle, head in 4B was higher than head in $4 \mathrm{Bb}$, indicating upwelling (Figure 20). Early in the study period, however, $4 \mathrm{Bb}$ was likely partially plugged so this apparent upwelling may be a product of post-installation instability. From 29 February to 4 March, heads in $4 \mathrm{~B}$ and 4Bb tracked very closely to one another, with $4 \mathrm{Bb}$ slightly higher in elevation than $4 \mathrm{~B}$, indicating downwelling during this time period. 


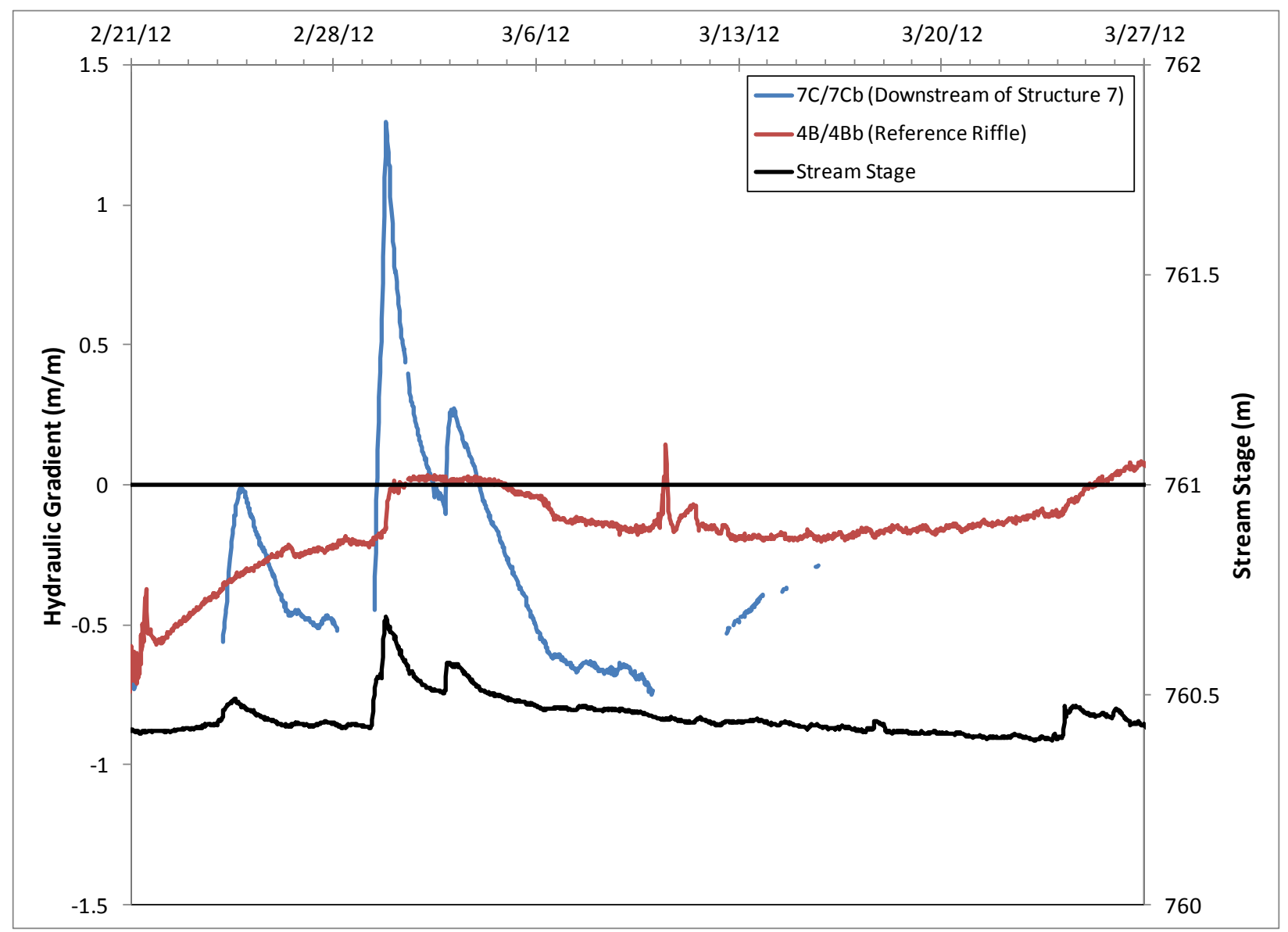

Figure 20: Vertical hydraulic gradients determined from hydrometric data. Positive values indicate downwelling, and the bold horizontal line at zero represents no gradient. Gaps in data indicate that at least one of these piezometers was dry during these time periods. Stream stage (right axis) was collected at Structure 6.

\section{Thermal Data}

\section{Raw Temperature Data}

Twenty-one temperature time series were collected from 18 February to 26 March 2012, distributed at three depths in the streambed at seven dowel locations (Figure 12). Examples of the temperature time series for the dowel installed upstream of Structure 5 are shown in Figure 21, and others are given in Appendix D. All 21 thermal signals depicted a seasonal warming with temperatures near 0 to $5{ }^{\circ} \mathrm{C}$ early in the study period and temperatures as high as 15 to 17 ${ }^{\circ} \mathrm{C}$ at the end. 
All iButtons detected a 24-hour diurnal fluctuation, and the amplitude of the diurnal fluctuations decreased with depth into the streambed for all sites except downstream of Structure 7, where scour exposed the $5 \mathrm{~cm}$ iButton. As a result, the thermal signals at $0 \mathrm{~cm}$ and $5 \mathrm{~cm}$ at this location were nearly identical and their amplitudes were not sufficiently different; therefore, flux calculations were not possible between these two sensors. Vertical water flux was calculated using VFLUX for all other iButton pairs.

Amplitudes of raw temperature signals indicate the relative influence of stream water and groundwater at the location of each iButton. Since groundwater maintains a nearly constant temperature while stream water temperature fluctuates daily, amplitudes should be larger if stream water dominates (Stonestrom and Constantz, 2003). As expected, the amplitudes for all

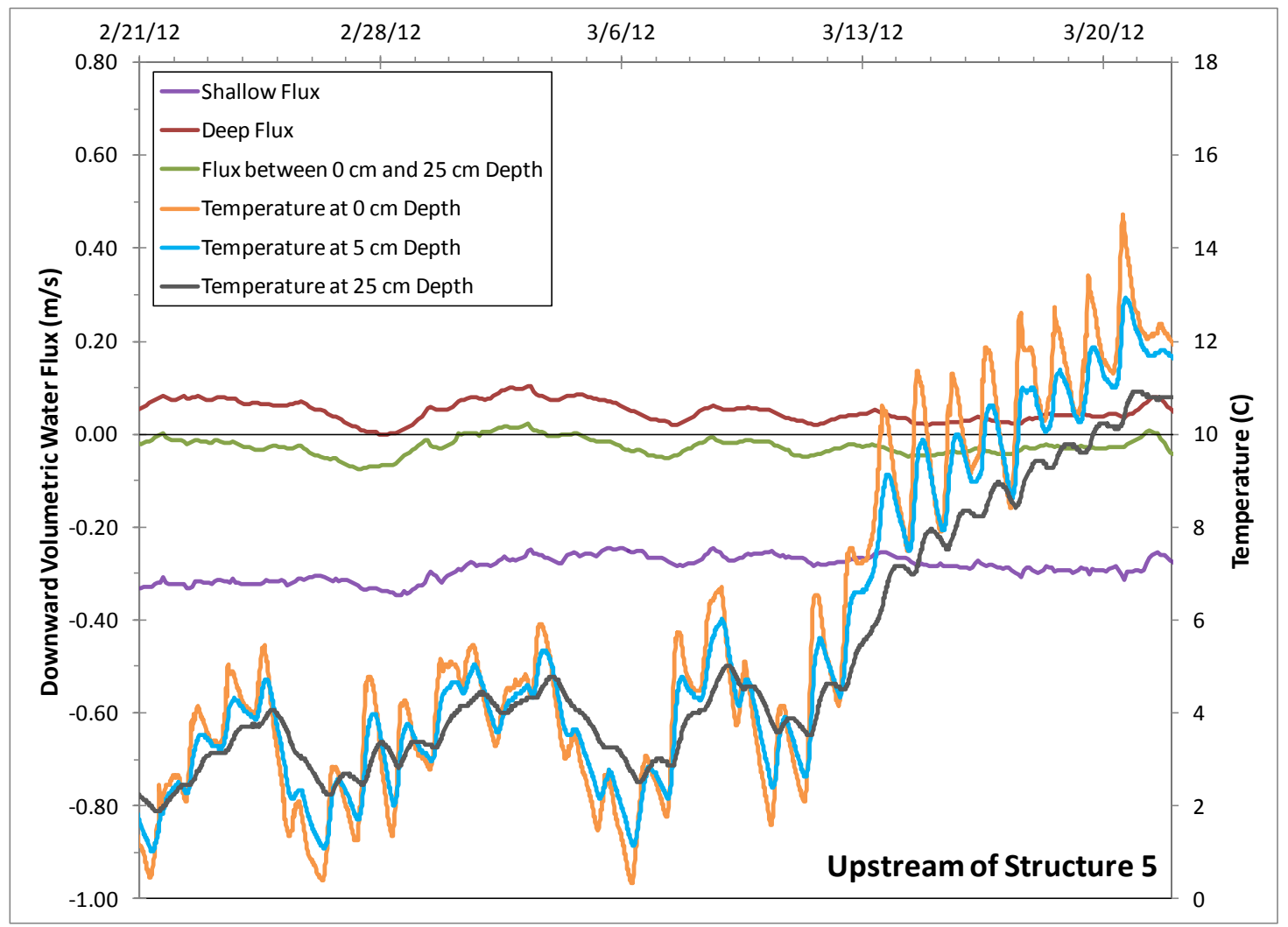

Figure 21: Temperature time series for 3 iButtons and hyporheic fluxes upstream of Structure 5. Positive flux values indicate downwelling, and the horizontal line at zero represents static flux. 
the $0 \mathrm{~cm}$ iButtons tracked very closely to one another, reflecting the temperature fluctuations in the stream (Figure 22). The temperature amplitude at the exposed $5 \mathrm{~cm}$ iButton downstream of Structure 7 also reflected stream temperature fluctuations (Figure 23). Temperature fluctuations at all other locations had lower amplitudes than the in-stream fluctuations, reflecting a moderating influence of nearly-constant temperatures deeper in the streambed (Figures 23, 24). The amplitudes for $5 \mathrm{~cm}$ and $25 \mathrm{~cm}$ iButtons revealed that the three iButton arrays at the reference site, downstream of Structure 6, and upstream of structure 7 indicated the greatest stream water influence. Fluctuations downstream of Structure 5 had the lowest amplitude, indicating the least surface water influence.

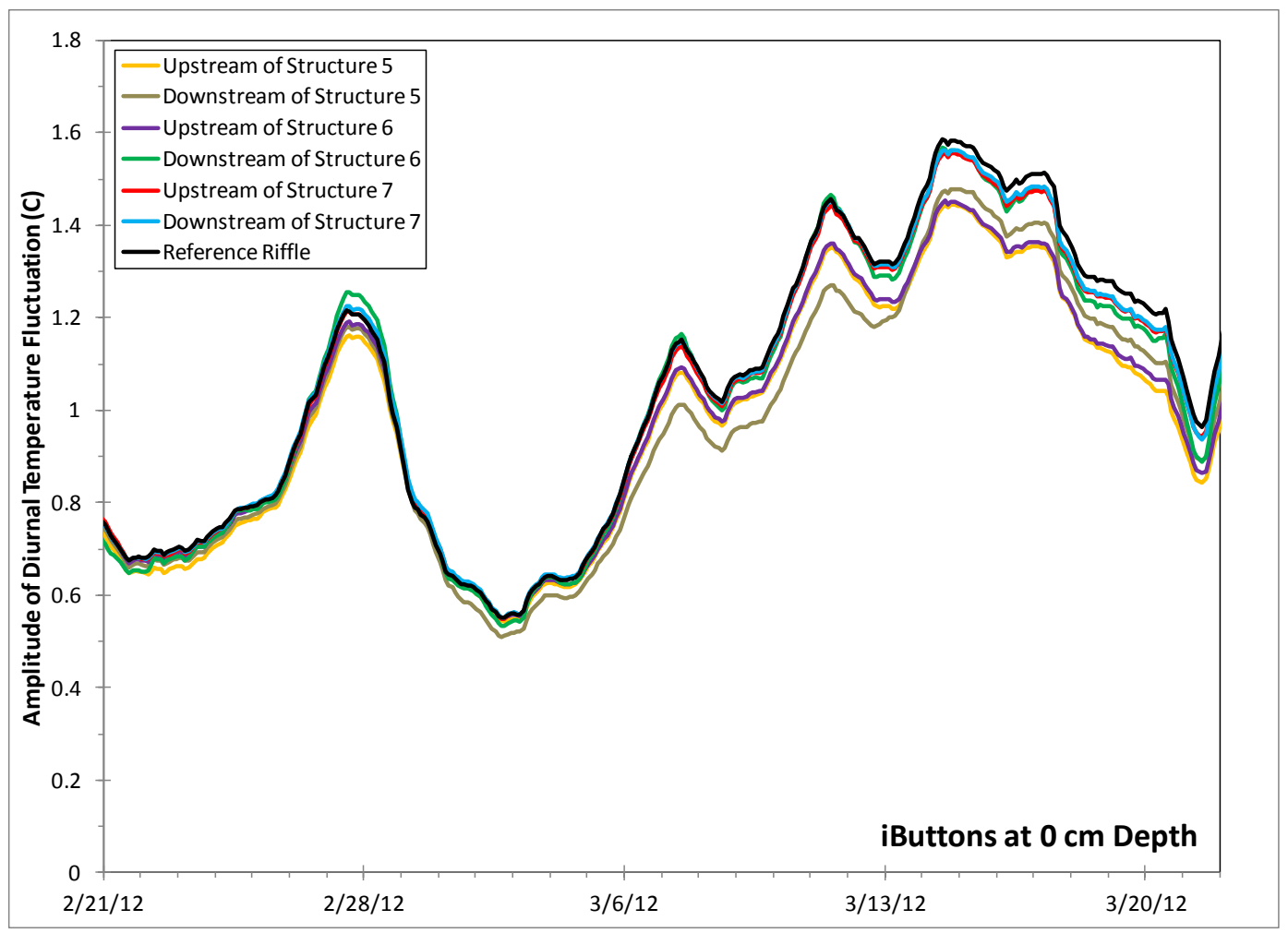

Figure 22: Diurnal temperature variation amplitudes for all iButtons at $0 \mathrm{~cm}$ depth. 


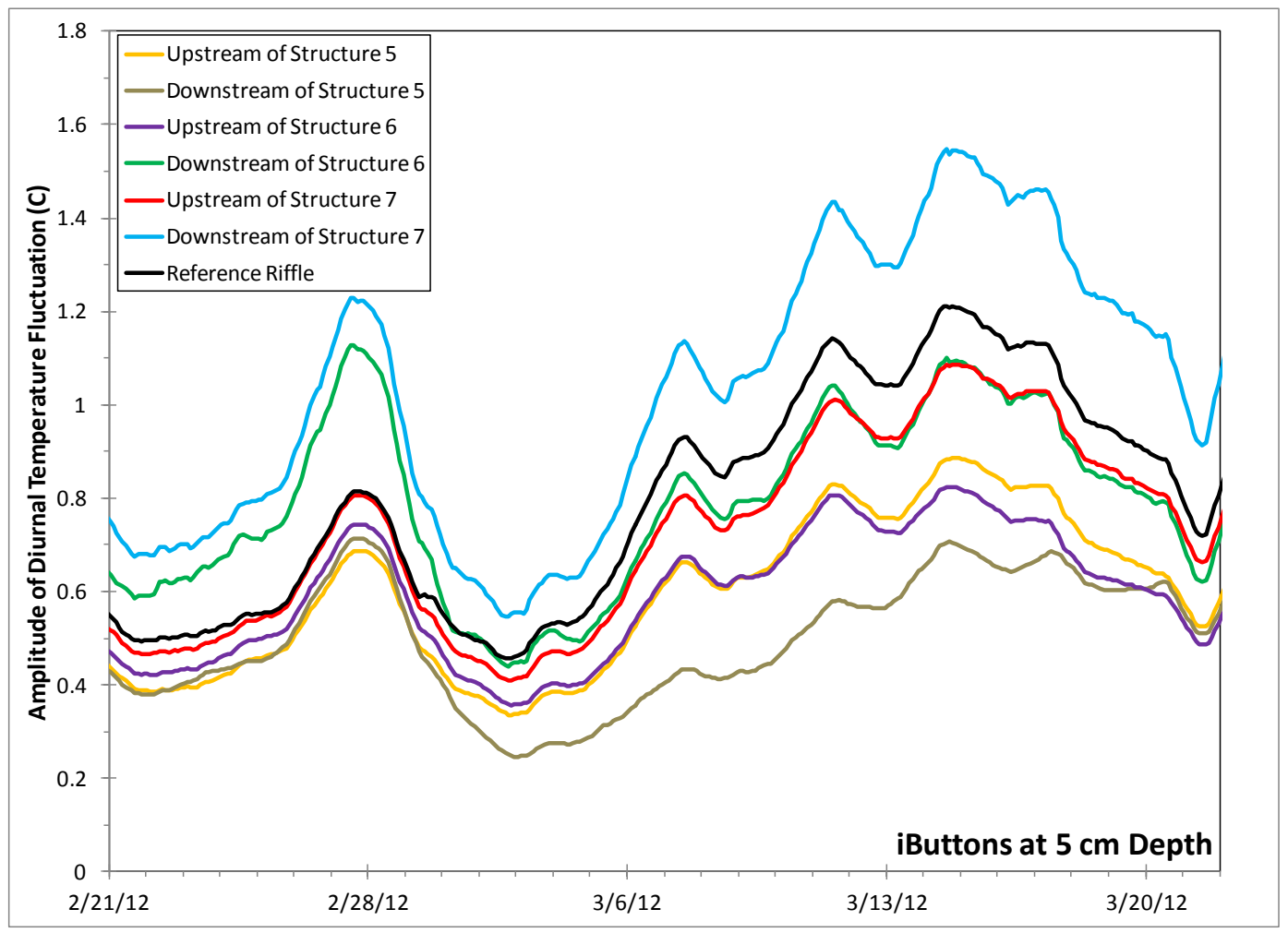

Figure 23: Diurnal temperature variation amplitudes for all iButtons at $5 \mathrm{~cm}$ depth.

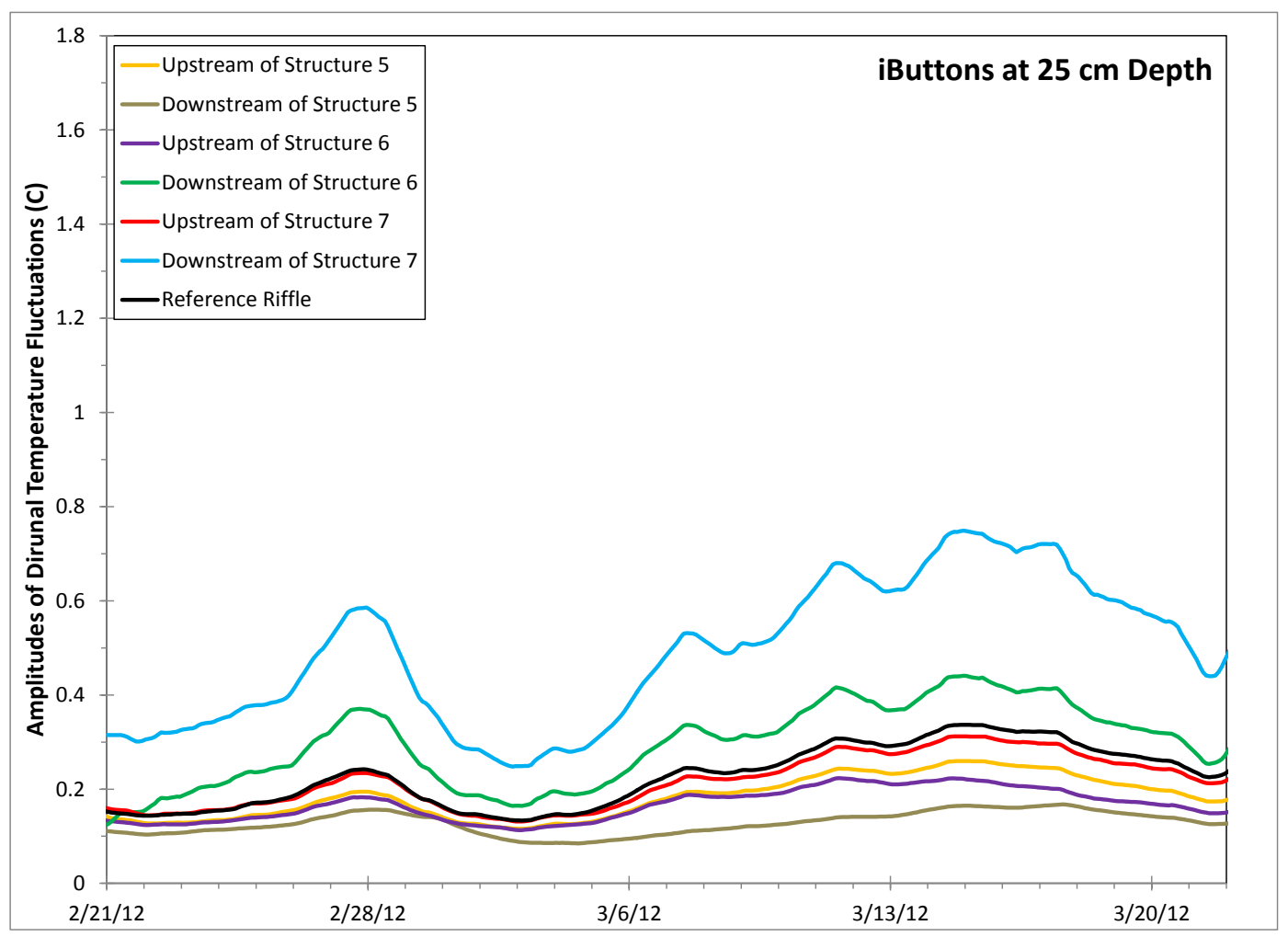

Figure 24: Diurnal temperature variation amplitudes for all iButtons at $25 \mathrm{~cm}$ depth. 


\section{Vertical Fluxes from Heat Transport Modeling}

Volumetric water flux results, as calculated via Equation 3 in VFLUX, are shown for each dowel location in Figures 25-31. At each dowel location, water flux was calculated between the shallow pair of iButtons $(0 \mathrm{~cm}$ and $5 \mathrm{~cm})$, the deep pair of iButtons $(5 \mathrm{~cm}$ and 25 $\mathrm{cm})$ and the uppermost and lowermost iButtons $(0 \mathrm{~cm}$ and $25 \mathrm{~cm})$. The flux calculated between $0 \mathrm{~cm}$ and $25 \mathrm{~cm}$ depicted an average of the fluxes calculated for the shallow and deep pairs and provided little information that was not shown by the other pairs. Thus, the flux between $0 \mathrm{~cm}$ and $25 \mathrm{~cm}$ upstream of Structure 5 is plotted on Figure 21 for demonstrative purposes and will not be discussed further; fluxes between $0 \mathrm{~cm}$ and $25 \mathrm{~cm}$ for all dowel locations are presented in Appendix D. The results of Monte Carlo error analyses for the shallow and deep pairs are plotted on Figures 25-31, showing a 95\% confidence interval around each flux calculation due to thermal parameter uncertainty. For most dowel locations, confidence intervals for the shallow and deep fluxes did not overlap, indicating different fluxes occurred at different depths in the streambed. For some dowel locations (indicated below), the confidence intervals overlapped with zero; consequently, it is possible that the true flux was zero at these locations, depending on the thermal parameters of the streambed. Estimated thermal parameters were used in this study, so the fluxes could be better constrained by determination of thermal parameters via substrate analysis (see Future Work).

Fluxes were low for all sites throughout the study period, ranging from a maximum downwelling of $0.66 \mathrm{~m} / \mathrm{d}(2.2 \mathrm{ft} / \mathrm{d}$; Figure 28$)$ to a maximum upwelling of $-0.73 \mathrm{~m} / \mathrm{d}(-2.4 \mathrm{ft} / \mathrm{d}$; Figure 26). Fluxes at the reference site were comparable in magnitude to fluxes in the constructed channel, which contrasts the results of Daniluk et al. (2012), who found hyporheic fluxes at restoration structures to be an order of magnitude higher than in corresponding 


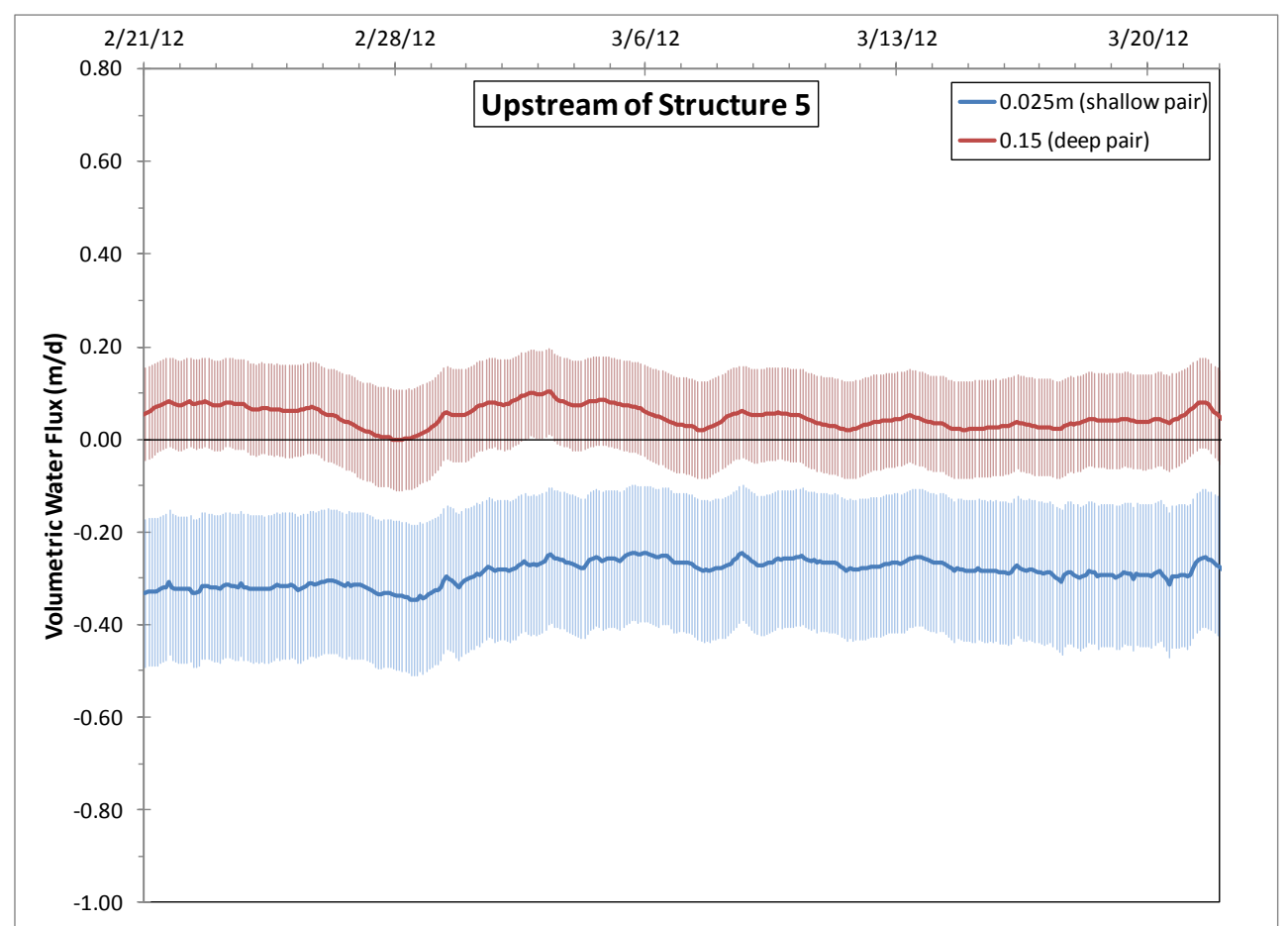

Figure 25: Shallow and deep vertical water fluxes upstream of Structure 5. The shaded area represents a confidence interval determined by Monte Carlo error analyses for thermal parameter uncertainty. Positive values indicate downwelling, and the horizontal line at zero represents static flux.

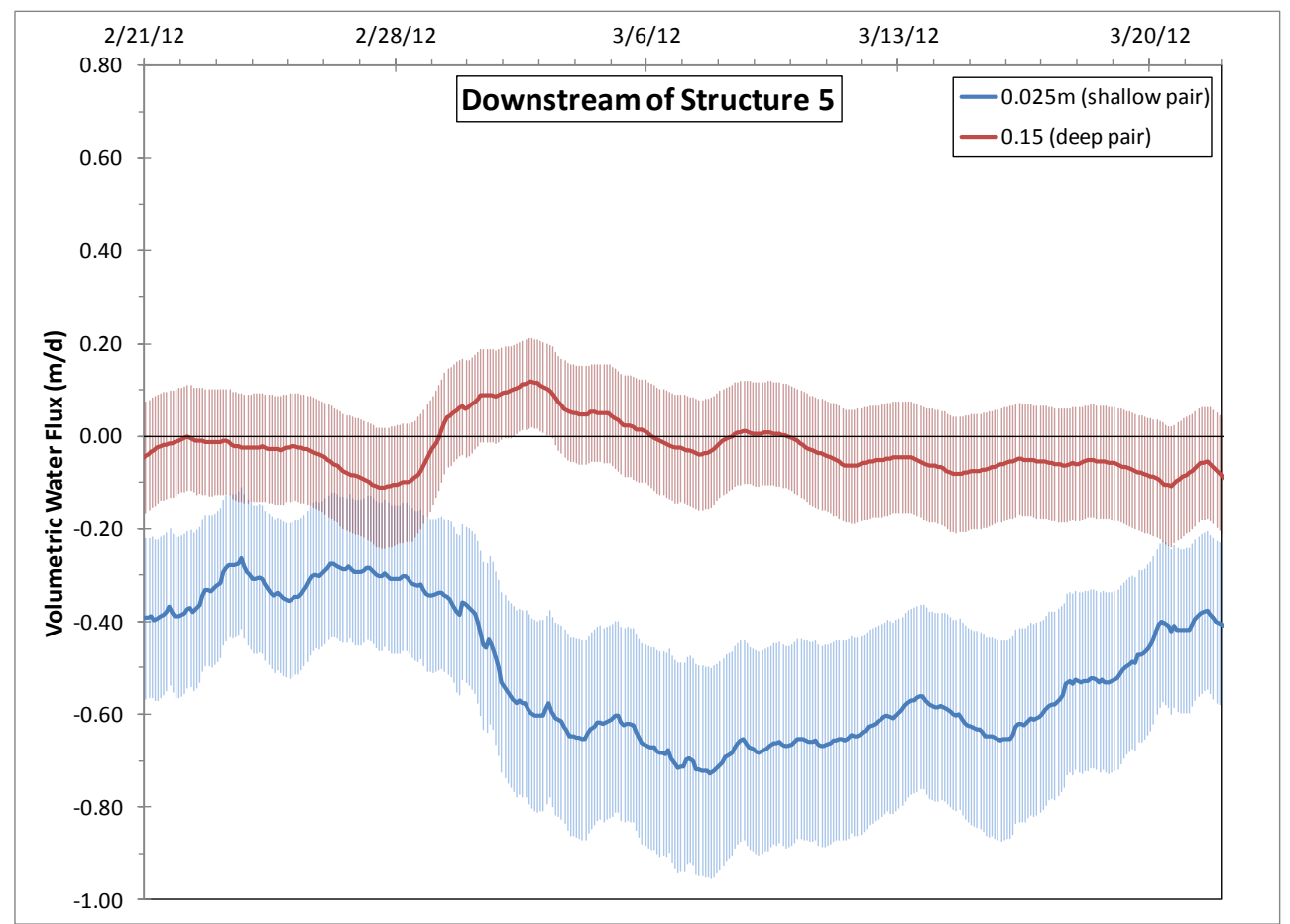

Figure 26: Shallow and deep vertical water fluxes downstream of Structure 5. The shaded area represents a confidence interval determined by Monte Carlo error analyses for thermal parameter uncertainty. Positive values indicate downwelling, and the horizontal line at zero represents static flux. 
unrestored reference channels.

Upstream of Structure 5, shallow flux was negative, indicating upwelling at this location (Figure 25). Deeper flux indicated slight downwelling, but the confidence interval overlapped with zero. The fluxes at both depths were relatively constant throughout the study period.

Downstream of Structure 5, shallow flux was upwelling throughout the study period with an increase in upwelling magnitude after the 29 February event (Figure 26). The magnitude remained elevated for about two weeks after the event before slowly declining to its pre-event magnitude. Deeper in the streambed, there was slight upwelling prior to the 29 February event. The high flow induced downwelling, forcing water into the streambed, followed by a slow, steady return to the pre-event upwelling magnitude by the end of the study period. The deep flux confidence interval overlapped with zero flux for all but a few hours of the study period.

Upstream of Structure 6, upwelling occurred in the shallow streambed throughout the study period with an increased upwelling magnitude later in the period (Figure 27). Deep flux remained relatively constant and was not confidently different than zero, except for some notable deviations - there was a short period of slight upwelling from 25 February to the start of the 29 February event followed by slight downwelling through 7 March.

Downstream of Structure 6, shallow flux was strongly downwelling early in the study period (Figure 28). The downwelling magnitude decreased during and after the 29 February event and eventually changed to slight upwelling on 10 March. Deeper flux was downwelling for most of the study period and increased slowly in magnitude through 6 March, after which it remained relatively constant.

Upstream of Structure 7, shallow flux was slightly upwelling early in the study period, decreased in upwelling magnitude in response to the 29 February event, switched to 


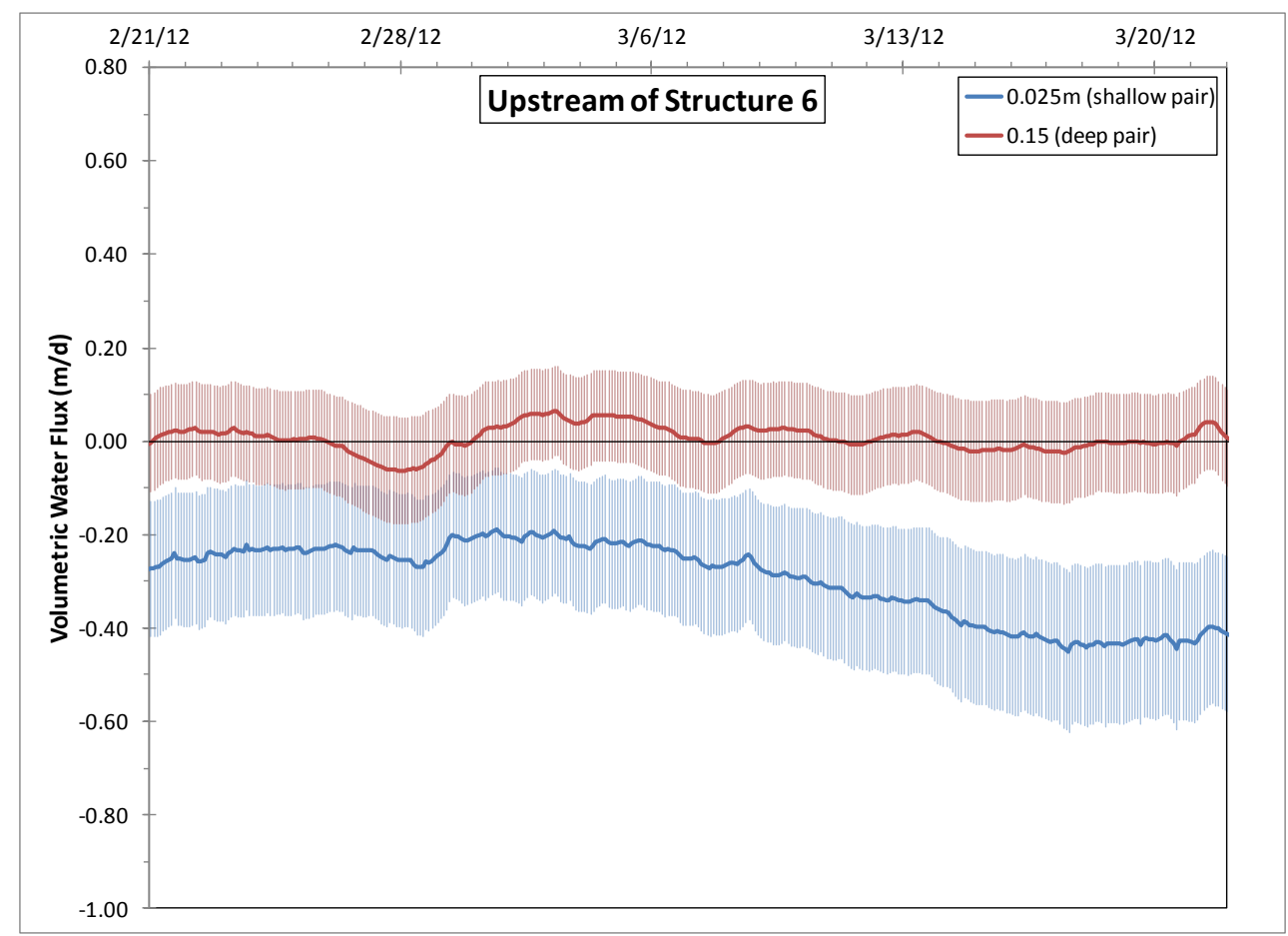

Figure 27: Shallow and deep vertical water fluxes upstream of Structure 6. The shaded area represents a confidence interval determined by Monte Carlo error analyses for thermal parameter uncertainty. Positive values indicate downwelling, and the horizontal line at zero represents static flux.

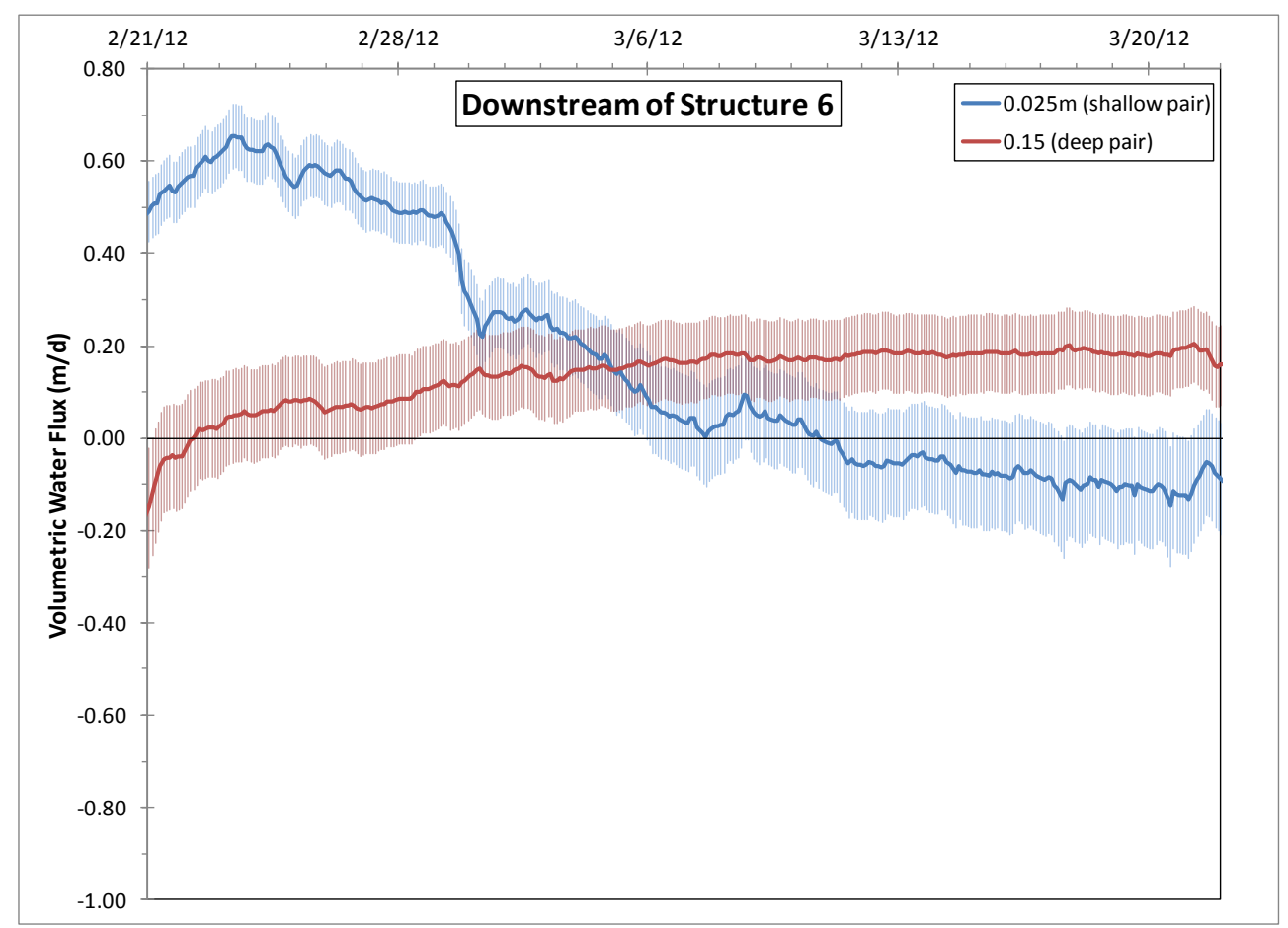

Figure 28: Shallow and deep vertical water fluxes downstream of Structure 6. The shaded area represents a confidence interval determined by Monte Carlo error analyses for thermal parameter uncertainty. Positive values indicate downwelling, and the horizontal line at zero represents static flux. 
downwelling on 2 March, then slowly returned to slightly upwelling (Figure 29). Deeper flux was very slightly downwelling and relatively constant. The flux at neither depth was confidently different from zero for most of the study period.

Downstream of Structure 7, deep flux was downwelling and relatively constant throughout the study period (Figure 30). Shallow flux was not calculated because the $5 \mathrm{~cm}$ iButton was exposed through scour.

At the reference riffle, shallow flux was slightly upwelling early in the study period, changed to moderately downwelling during the 29 February event, then steadily decreased in downwelling magnitude (Figure 31). Deeper flux was slightly downwelling before the 29 February event but was essentially zero for the rest of the period.

Figure 32 indicates flux direction (upwelling, downwelling, or approximately zero flux) at each iButton dowel location for two end- member scenarios: flux directions on 22 February (Figure 32a) represent the 'dry' conditions prior to the 29 February precipitation event, and flux directions on 3 March (Figure 32b) represent changes in flux directions resulting from the 29 February and 2 March events. 


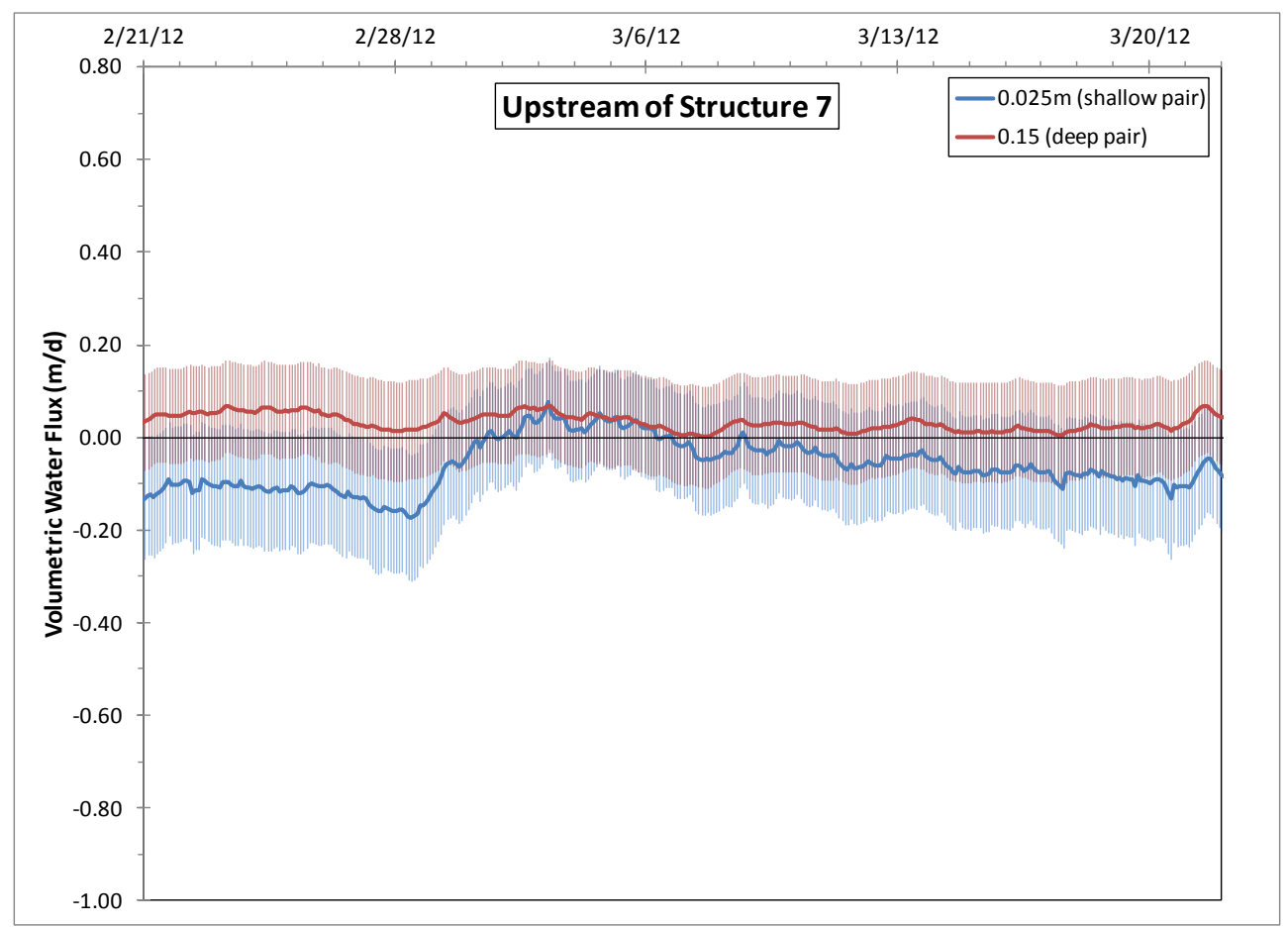

Figure 29: Shallow and deep vertical water fluxes upstream of Structure 7. The shaded area represents a confidence interval determined by Monte Carlo error analyses for thermal parameter uncertainty. Positive values indicate downwelling, and the horizontal line at zero represents static flux.

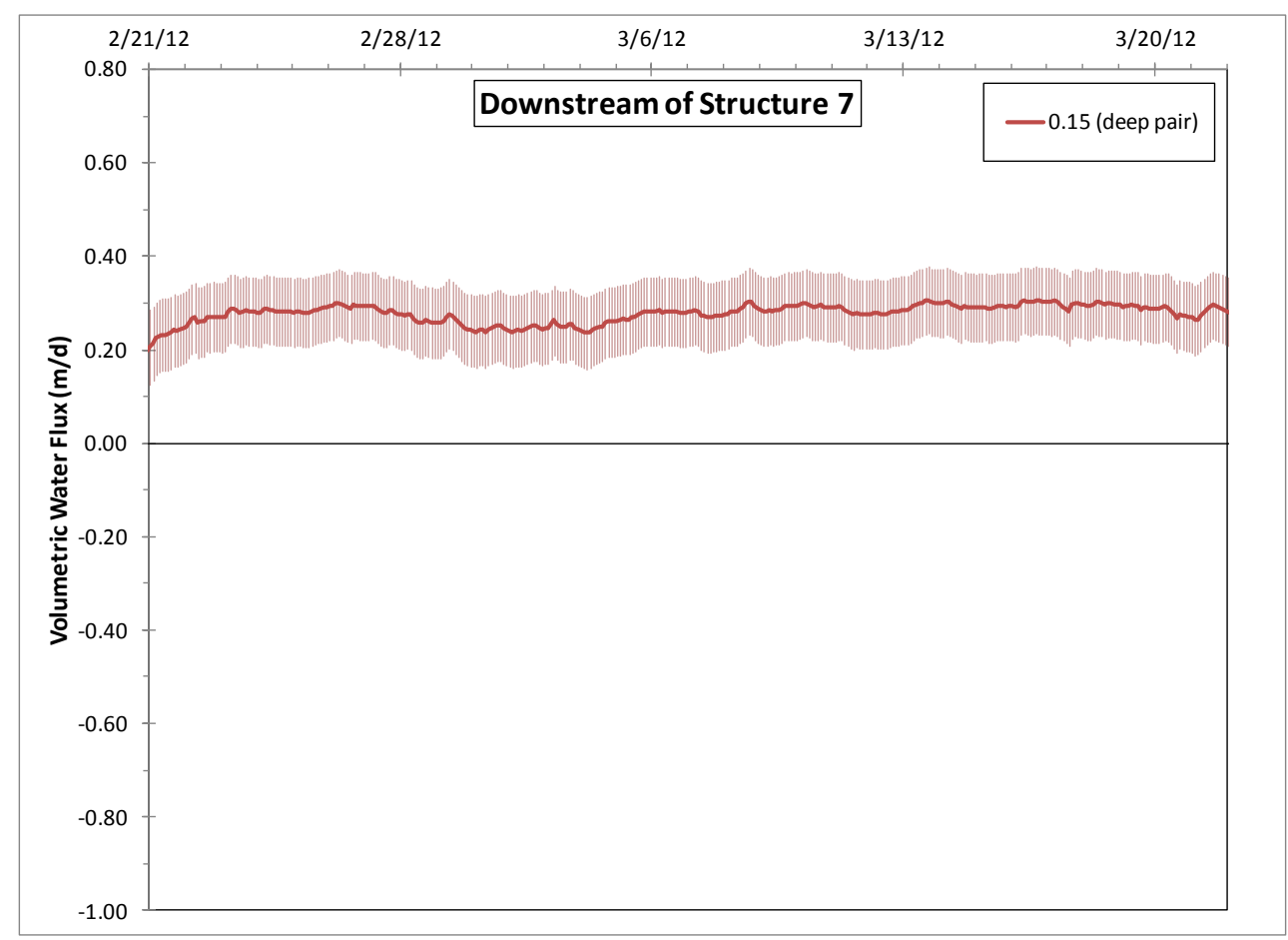

Figure 30: Deep vertical water flux downstream of Structure 7. Shallow flux was not calculated for this location because streambed scour exposed the $5 \mathrm{~cm}$ iButton. The shaded area represents a confidence interval determined by Monte Carlo error analyses for thermal parameter uncertainty. Positive values indicate downwelling, and the horizontal line at zero represents static flux. 


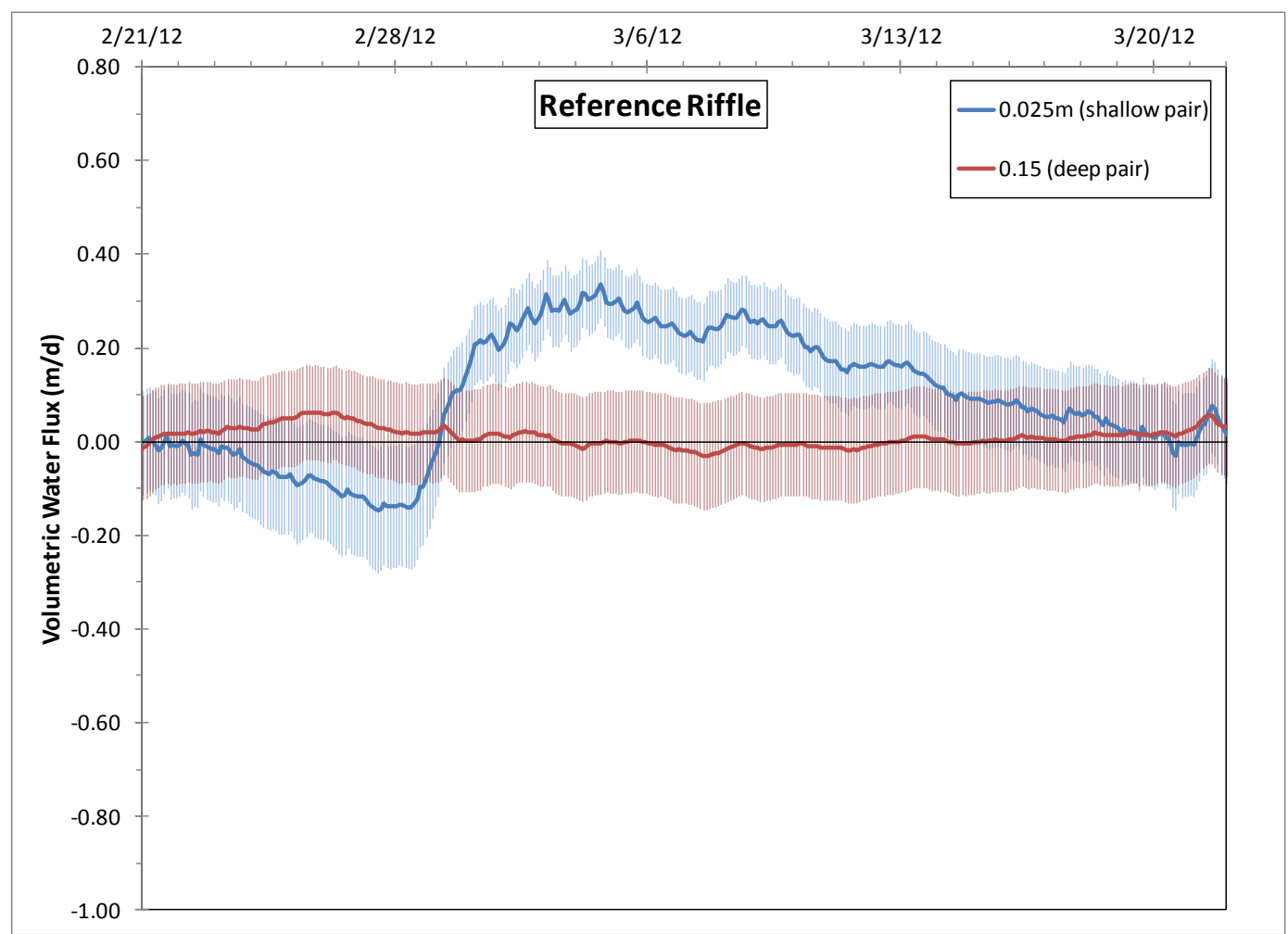

Figure 31: Shallow and deep vertical water fluxes at the reference riffle. The shaded area represents a confidence interval determined by Monte Carlo error analyses for thermal parameter uncertainty. Positive values indicate downwelling, and the horizontal line at zero represents static flux. 


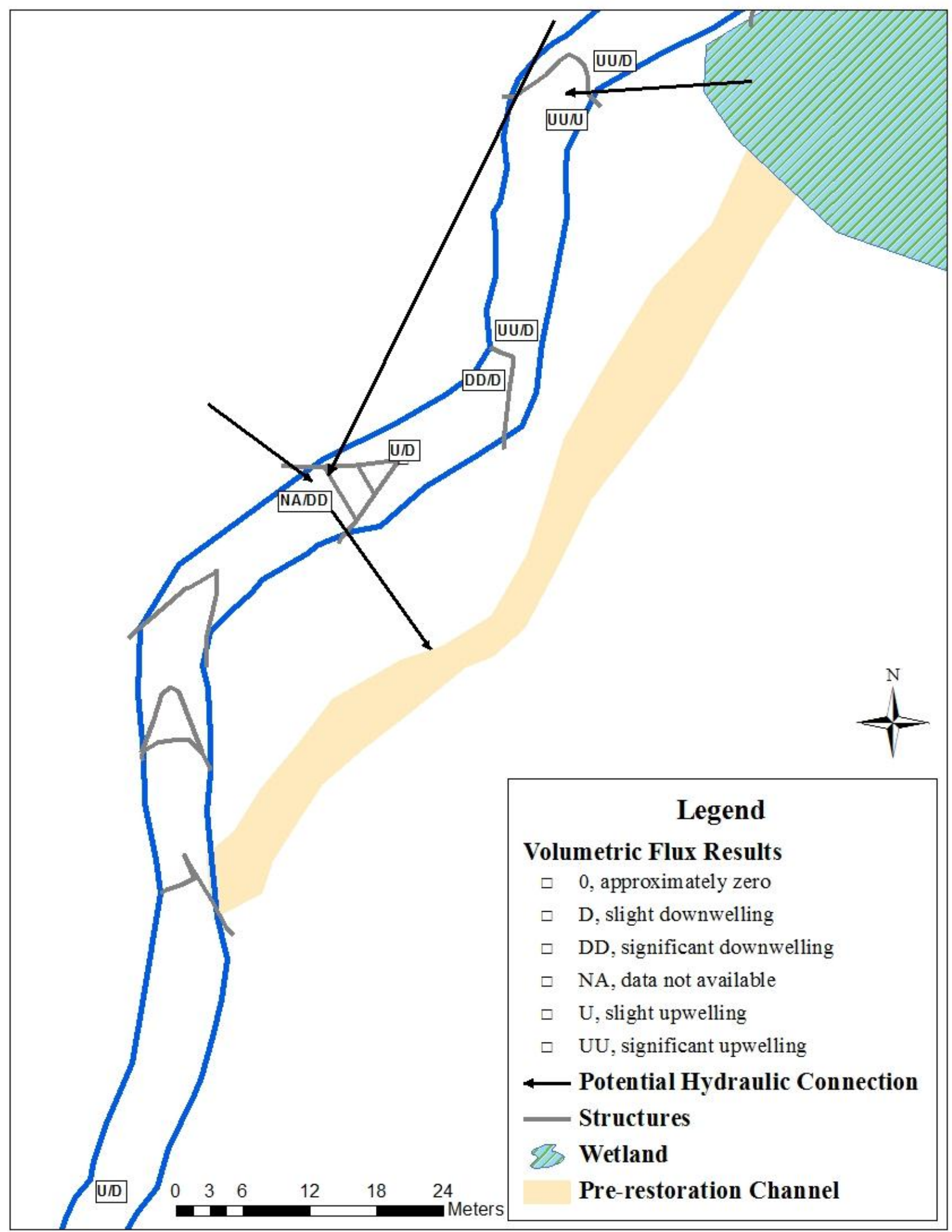

Figure 32a: Map view of flux results for 22 February and potential hydraulic connections. Shallow and deep fluxes are presented as "shallow/deep" at each iButton dowel location. Hydraulic connection arrows are intended to illustrate generalized, potential relationships revealed by the hydrometric data and do not indicate confirmed flow paths. 


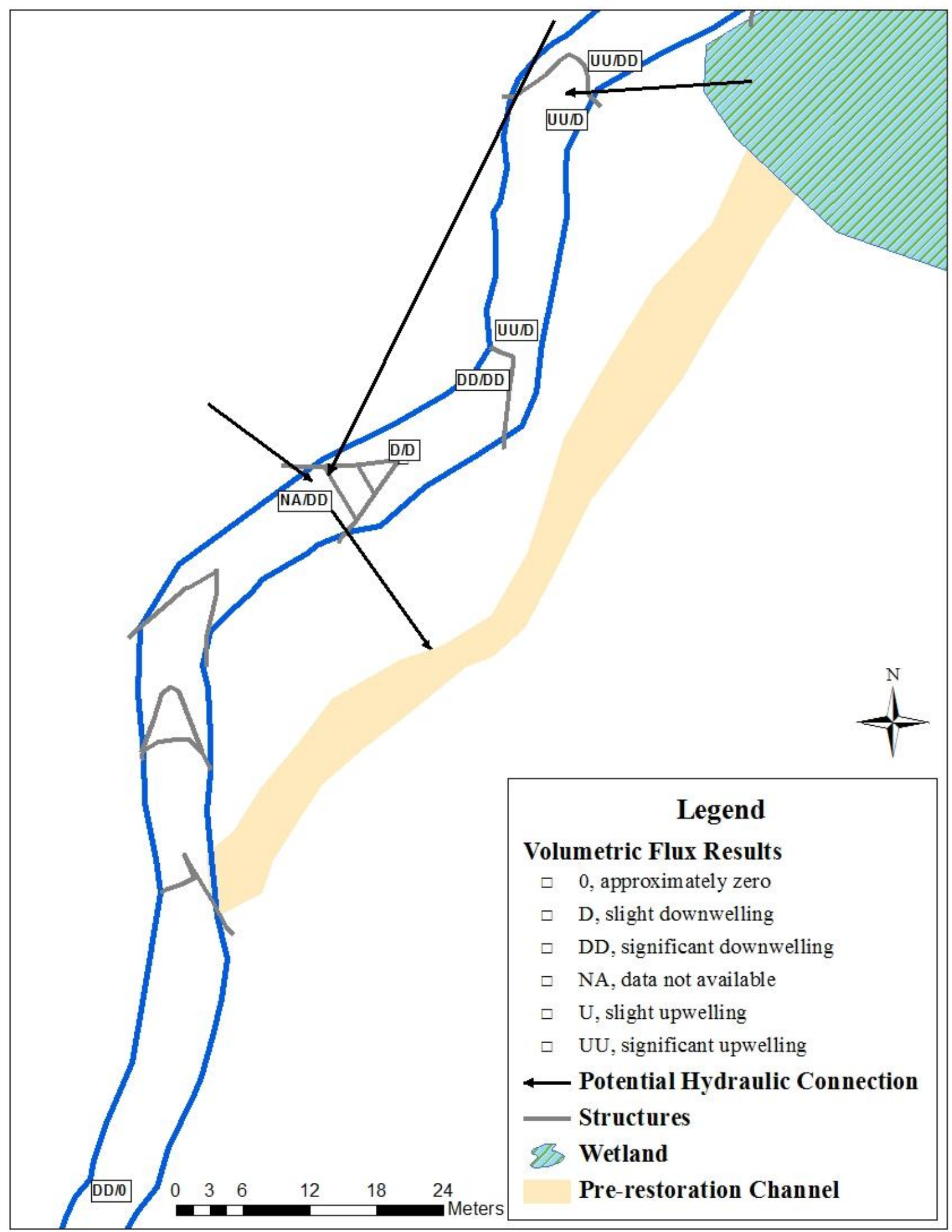

Figure 32b: Map view of flux results for 3 March and potential hydraulic connections. Shallow and deep fluxes are presented as "shallow/deep" at each iButton dowel location. Hydraulic connection arrows are intended to illustrate generalized, potential relationships revealed by the hydrometric data and do not indicate confirmed flow paths. 


\section{Discussion}

\section{Hydraulic Connections between the Constructed Stream and the Subsurface}

In a system where hydraulic connections exist between a stream and a shallow aquifer, the aquifer responds to changes in stream stage. Consequently, water levels in piezometers installed in the aquifer should rise and fall similarly to stream stage. In connected stream-aquifer systems, the aquifer response cannot be greater in magnitude than the change in stream stage (Shanafield et al., 2012). This pattern was clearly shown only in one of the piezometers, 5A (Figure 17b); thus, 5A was the only piezometer unambiguously connected to the stream during the study. The following discussion explores possible explanations for the hydrometric signals in the other piezometers.

The lack of response in 5C's hydrometric signal to stream stage indicated a low degree of hydraulic connectivity to stream stage (Figure 17). The amplitudes of the raw temperature signals downstream of Structure 5 supported minimal stream water influence, since these amplitudes were the lowest of all $5 \mathrm{~cm}$ and $25 \mathrm{~cm}$ iButtons (Figures 23, 24). There are several possible explanations for minimal stream connectivity, the simplest of which is that the piezometer may have been partially plugged by fine-grained material. Similarly, the piezometer opening may have been installed in a lens of fine-grained material less hydraulically conductive than materials elsewhere in the streambed. Both these scenarios could result in a muted hydrometric response that exhibits some seasonal fluctuations, as seen for piezometer 5C (Figure 17; Appendix A), but the second scenario could also explain the thermal amplitude indicating minimal stream water influence if the iButton dowel was installed in the less permeable material.

Piezometer 5C's proximity to the wetland provides another possible explanation for the nearly static hydrometric signal and minimal stream water influence. Although water level in the 
wetland was not continuously monitored, field observations during the study period indicated that the water level in the wetland was approximately static. Water level in an aquifer hydraulically controlled by the wetland would also have been nearly static. If groundwater flowed from the wetland to piezometer $5 \mathrm{C}$, then hydraulic head should have been higher in piezometer W (installed in the wetland, Figure 12) than in 5C. Hydraulic heads were measured manually on 2 March and 11 March; head in piezometer W was higher than head in 5C on both occasions, by $0.87 \mathrm{~m} \mathrm{(2.9ft)} \mathrm{and} 0.80 \mathrm{~m}(2.6 \mathrm{ft})$, respectively. Additionally, water flux results indicated shallow upwelling downstream of Structure 5 (Figure 26), supporting that groundwater flow paths may have terminated in the pool downstream of Structure 5. Thus, it is plausible that subsurface flow paths from the wetland to piezometer $5 \mathrm{C}$ existed during the study period, but further work, such as a conservative tracer experiment, would be needed to confirm the hydraulic connection between the wetland and piezometer $5 \mathrm{C}$.

Piezometers 7A, 7Ab and 7Cb (Figure 18b) were dry at low stream stage during the study period, indicating that the streambed near Structure 7 was unsaturated while the stream was flowing. Shanafield et al. (2012) define a disconnected stream-aquifer system as one in which an unsaturated zone is present beneath the stream, so the dry piezometers may have indicated a hydraulic disconnection between the stream and the subsurface.

Additional data supported that the stream-aquifer system may have been disconnected near Structure 7. Table 6 shows responses to the 23-25 February and 29 February to 2 March events for stream stage and the piezometers installed at Structure 7. Responses in piezometers 7A, 7Ab and 7Cb exceeded the change in stream stage. Shanafield et al. (2012) showed through numerical modeling that this response is only possible in a disconnected stream-aquifer system. Additionally, during the 24 February event, 7Ab (the shallower piezometer) was dry and 
Table 6: Water level responses to precipitation events of stream stage and Structure 7 piezometers.

\begin{tabular}{|l|r|c|r|c|c|}
\cline { 2 - 6 } \multicolumn{1}{c|}{} & \multicolumn{5}{c|}{ Water Level Rise (m) } \\
\hline Storm Event & Stream Stage & 7A & \multicolumn{1}{c|}{ 7Ab } & 7C & 7Cb \\
\hline 23-25 February & 0.062 & 0.152 & dry & 0.014 & 0.177 \\
\hline 29 Febaruary - 2 March & 0.263 & 0.526 & 0.294 & 0.238 & 0.621 \\
\hline
\end{tabular}

hydraulic head in 7A was lower in elevation than the installation depth of 7Ab. During the 29 February event, piezometer 7A started responding to the event before $7 \mathrm{Ab}$ received water. Thus, there was a bottom-up response to both events at this location - the water table rose up from below 7Ab.

Lateral recharge to piezometers $7 \mathrm{~A}, 7 \mathrm{Ab}$ and $7 \mathrm{Cb}$ must have occurred during the precipitation events to account for the large head changes. Possible sources of recharge include hillslope contributions or large-scale hyporheic flow paths that conveyed water from much farther upstream and terminated near Structure 7 (Figure 32). Unfortunately, the sparse network of piezometers installed during this study did not indicate the source of this recharge, but future work could utilize MODFLOW flow modeling to decipher recharge flow paths.

Based on the extrapolated stream stage data for Structure 7 (see assumptions in "Structure 7 Piezometer Fluctuations and Stream Stage" in Results), hydraulic head in the stream was higher than heads in 7C and 7Cb during the study period (Figure 18b). Thus, water was downwelling when the shallow streambed (piezometer $7 \mathrm{Cb}$ ) was unsaturated. The results of the heat transport model (Figure 30) were consistent with downwelling throughout the study period, as was the amplitude of the raw temperature signal at the deepest iButton which showed the greatest surface water influence of all $25 \mathrm{~cm}$ iButtons (Figure 24). If downwelling occurred, the hydraulic conductivity of the streambed at piezometer $7 \mathrm{Cb}$ was high enough to move water 
laterally away from the streambed faster than it infiltrated.

The scenarios discussed above indicate that water could have been flowing both laterally away (downwelling from the stream) and laterally toward (recharge from an unidentified source) the pool downstream of Structure 7. Another factor complicating flow patterns was the proximity of the hydraulically-lower pre-restoration channel (Figure 12), which may have generated a hydraulic gradient away from the newly constructed channel and acted as a sink. Recharge flow paths may have existed between the hillslope west of the constructed channel and the pool downstream of Structure 7, but could also have passed under the constructed channel and fed into the pre-restoration channel (Figure 32). In this scenario, the water table beneath the constructed channel would have fluctuated with recharge on the stream banks, but all water, including that infiltrated from the constructed channel, would have flowed towards the prerestoration channel. Hydrometric data from piezometers installed on the adjacent stream banks should have shown a signal similar to 7C, but data collected from piezometers 7B and 7D during fall and winter 2011 were uninformative (Figure 12; Appendix A). Future work is needed to elucidate the relationship between the constructed and pre-restoration channels; a denser network of piezometers could reveal isolated flow paths not detected within piezometers 7B and 7D, or a conservative tracer experiment could indicate a hydraulic connection between the two channels.

Hydrometric evidence at both Structures 5 and 7 indicated that groundwater flow patterns and streambed hydraulic conductivities were highly heterogeneous. At Structure 5, piezometer $5 \mathrm{~A}$ was unambiguously connected to the stream, while piezometer $5 \mathrm{C}$ was either installed in low conductivity material or was hydraulically connected to the wetland. Piezometer 7C's subdued behavior compared to the other Structure 7 piezometers suggested that it may have been installed in less permeable material. Large responses to flow events in three Structure 7 piezometers 
indicated that lateral recharge to the subsurface must have occurred, but downwelling from the stream occurred at the same time. Despite results that indicated consistent downwelling from the stream throughout the study period, the hydraulic gradient between $7 \mathrm{C}$ and $7 \mathrm{Cb}$ changed direction during the study period (Figure 20), indicating smaller scale heterogeneities also existed.

These complexities are consistent with the findings of Gordon et al. (in press), who found high heterogeneity in hyporheic exchange patterns near restoration structures due to the presence of secondary bedforms. Unfortunately, the sparse instrumentation and lack of detailed streambed mapping at Savage River did not allow for adequate characterization of heterogeneities. Future work should include a denser instrumentation network to better characterize flow pattern heterogeneities, as well as slug tests in the piezometers to characterize heterogeneities in hydraulic conductivity.

Hydrometric evidence also indicated that flow paths between the constructed channel and the shallow aquifer may not have fully developed in the first 16 months after restoration. Shallow hyporheic exchange occurred in some locations, but larger scale flow paths, such as those between the constructed channel and the wetland or the pre-restoration channel, may overprint the stream-subsurface dynamics. Hydraulic disconnection could be a byproduct of restoration and hydraulic connections may evolve with time.

\section{Comparison of Reference Reach and Constructed Channel}

There were notable differences in hydraulic head response magnitudes between study sites (Figures 17, 18, 19). Both piezometers at the reference site $(4 \mathrm{~B} / 4 \mathrm{Bb})$ showed less response to changes in stream stage than the piezometers in the constructed channel. This slow, minimal 
response may indicate a less permeable streambed at the reference site. This indication was supported by field observations during removal of dowels; the reference riffle dowel was stuck into the streambed by fine-grained material and had to be dug out, rather than pulled out like the dowels in the constructed channel.

While the piezometers in the constructed channel showed greater responses to stream stage changes than those at the reference riffle, piezometer 5A's responses were more subdued than those at Structure 7. This pattern supports the discussion in the "Hydraulic Connections between the Constructed Stream and The Subsurface" section: piezometer 5A is hydraulically connected to the stream, while the piezometers at Structure 7 received additional recharge from an unidentified source.

\section{Hyporheic Flux Patterns at Restoration Structures}

Several patterns emerge in Figures 33 and 34, which show all the water flux results upstream of restoration structures and in the reference riffle. Shallow upwelling upstream of structures occurred for most of the study period (Figure 33). During the 29 February event, upwelling decreased or downwelling started for all the structures and the reference riffle. Thus, as stream stage rose during the event, head along the streambed increased at each of these sites. Each site responded differently after the event, which likely reflected local conditions. Flux upstream of Structure 5 remained relatively constant, which may reflect its proximity to the wetland or installation in low conductivity material. The reference riffle and the bed of the channel upstream of Structures 6 and 7 slowly returned to pre-event conditions, less downwelling or more upwelling, as pressure head decreased along the streambed.

The magnitude of deep flux was much smaller (not confidently different from zero) than 


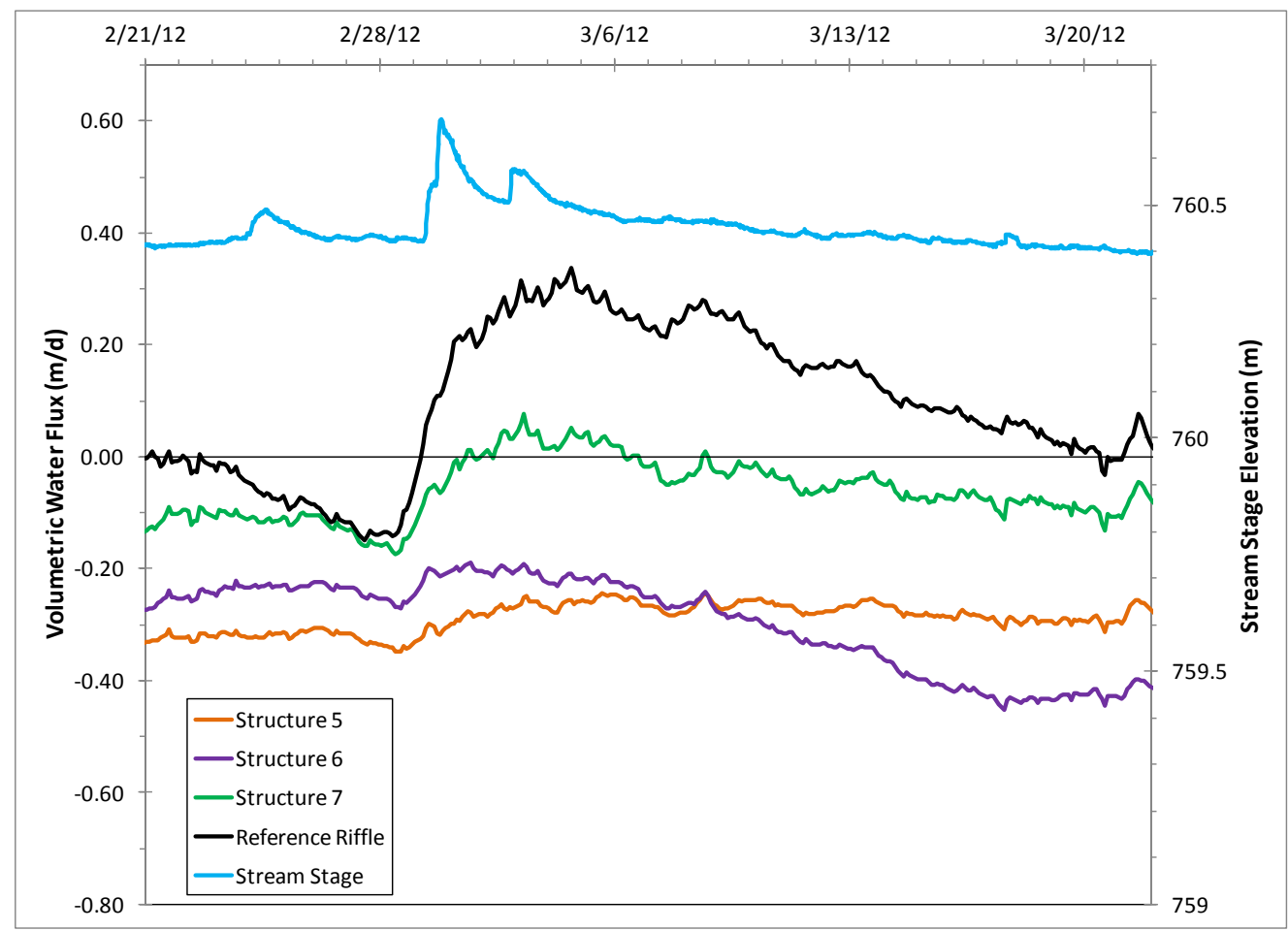

Figure 33: Shallow fluxes upstream of restoration structures and at the reference riffle. Positive values indicate downwelling, and the horizontal line at zero represents static flux. Stream stage (right axis) was measured at Structure 6.

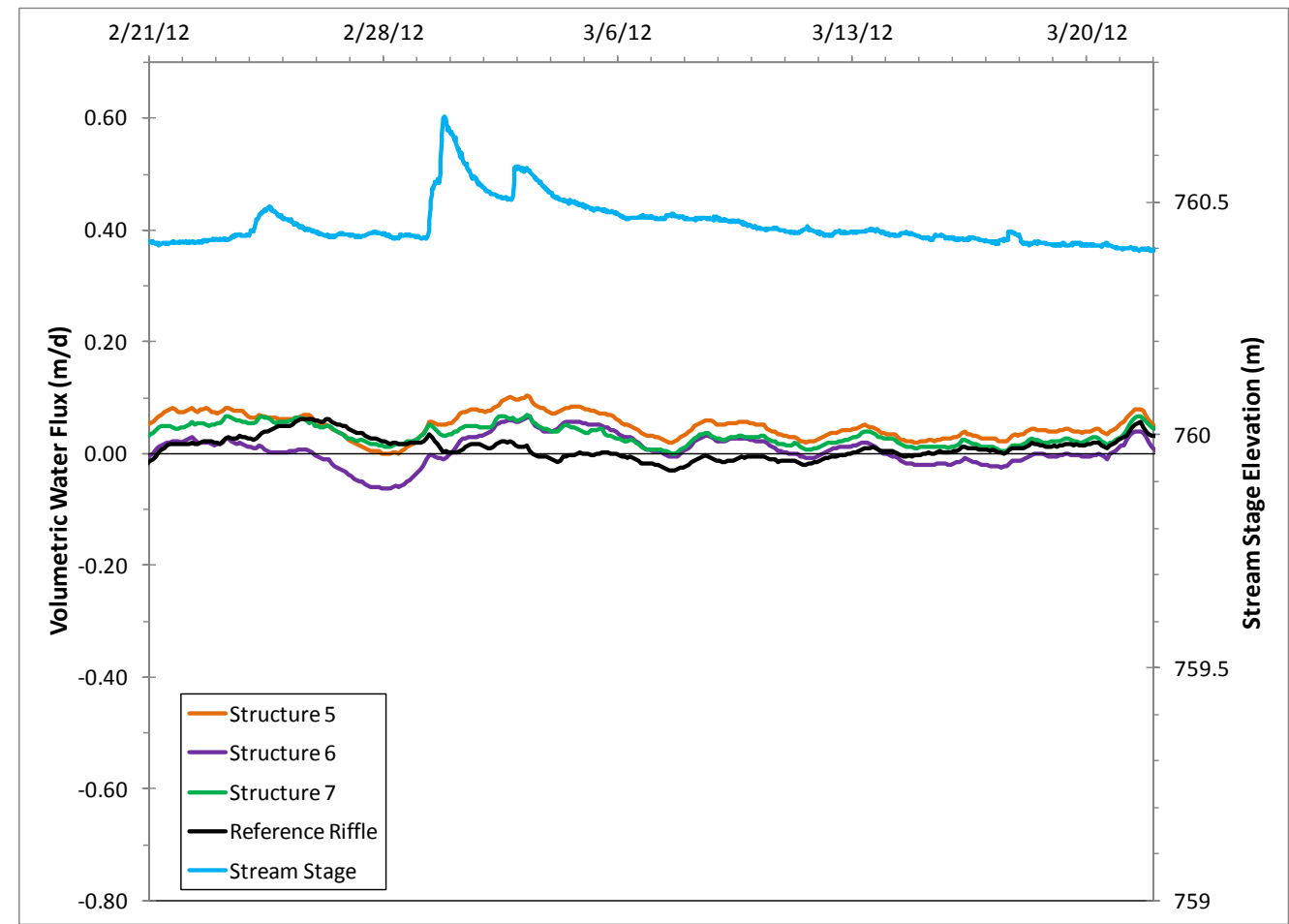

Figure 34: Deep fluxes upstream of restoration structures and at the reference riffle. Positive values indicate downwelling, and the horizontal line at zero represents static flux. Stream stage (right axis) was measured at Structure 6. 
the magnitude of shallow flux at all upstream locations and for the reference riffle (Figure 34). This pattern is consistent with the results of Briggs et al. (2012) and Gordon et al. (in press). These studies attributed the pattern to the curved shape of hyporheic flow cells around geomorphic steps: flow paths were initially vertical but transitioned to horizontal with depth (Buffington and Tonina, 2009). The effects of non-vertical flow, which violates the Hatch et al. (2006) model, are discussed further in the "Uncertainties in Heat Transport Modeling Results" section.

Flux downstream of restoration structures showed notably different patterns from flux upstream of structures (Figures 35 and 36). Shallow upwelling occurred downstream of Structure 5 throughout the study, and the magnitude of upwelling increased in response to the 29 February event (Figure 35). Downstream of Structure 6, shallow flux was strongly downwelling early in the study period, but downwelling decreased in magnitude in response to the 29 February event and eventually crossed over to slightly upwelling. Thus, as stream stage rose during the high flow event, head along the streambed decreased at each of these sites. This pattern is opposite of that upstream of the structures and at the reference riffle.

Deep flux downstream of structures exhibited variations between sites and did not exhibit the same tendency towards zero flux as deep flux upstream of structures (Figure 36). Downstream of Structure 7, deep flux was moderately downwelling and nearly constant throughout the study period. Downstream of Structure 6, deep flux was initially near zero but reached a constant downwelling magnitude on 3 March. Deep flux downstream of Structure 5 was slightly upwelling before and after the 29 February event, with a 6-day period of slight downwelling induced by the event. 


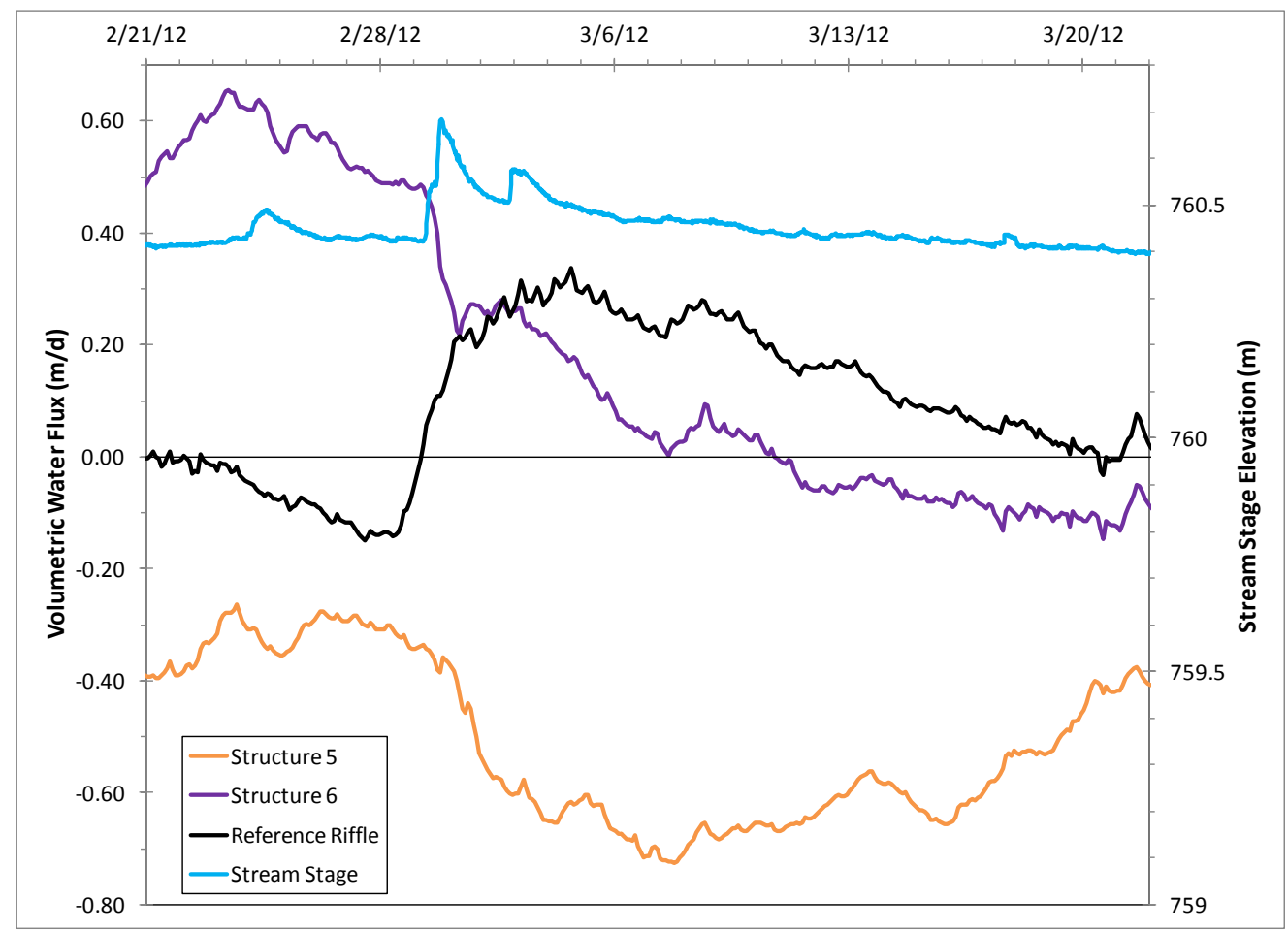

Figure 35: Shallow fluxes downstream of restoration structures and at the reference riffle. Positive values indicate downwelling, and the horizontal line at zero represents static flux. Stream stage (right axis) was measured at Structure 6.

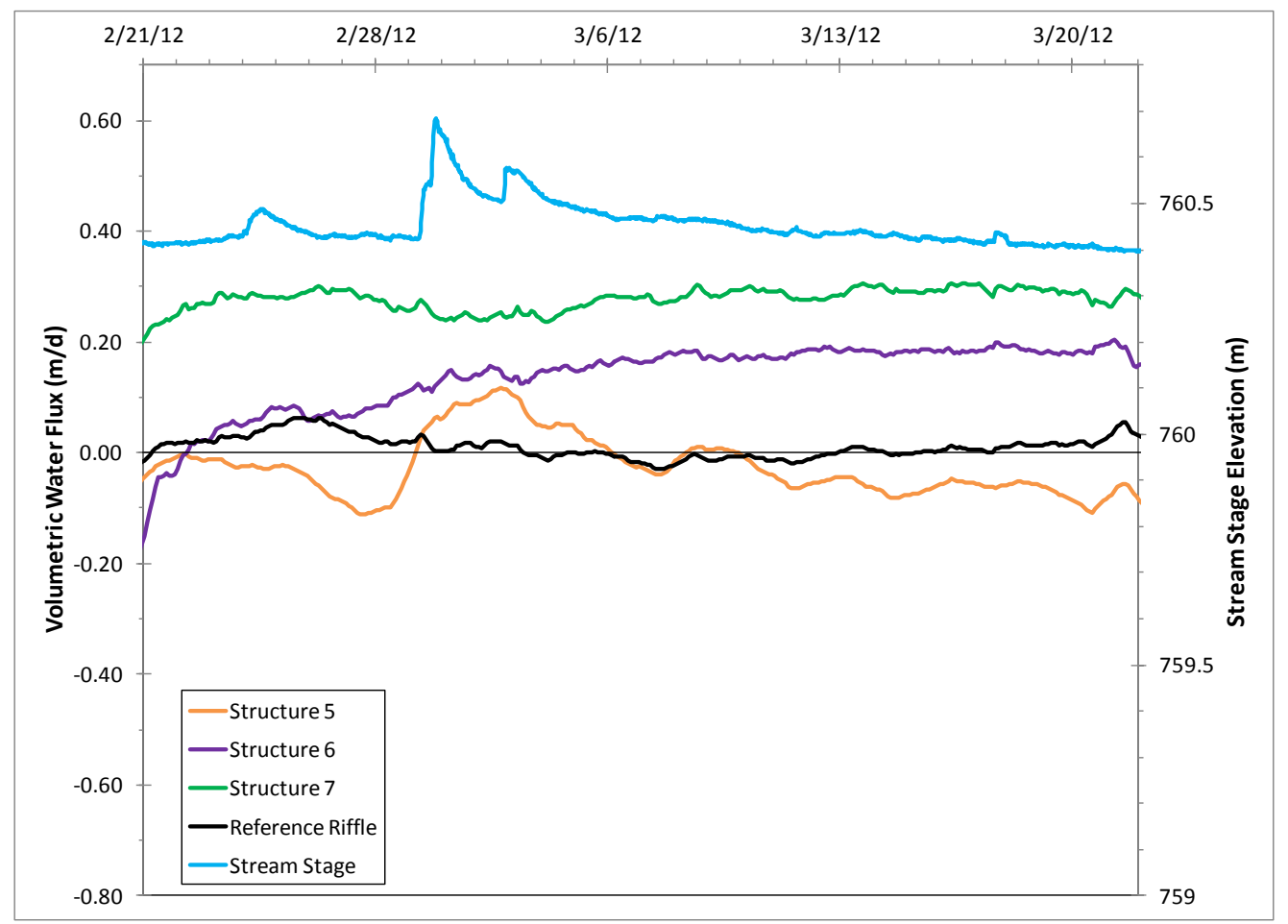

Figure 36: Deep fluxes downstream of restoration structures and at the reference riffle. Positive values indicate downwelling, and the horizontal line at zero represents static flux. Stream stage (right axis) was measured at Structure 6. 


\section{Uncertainties in Heat Transport Modeling Results}

Upon removal of the iButton dowels, it was noted that streambed scour at some of the installation sites changed the sensor spacing ( $\Delta \mathrm{z}$ in Equation 3) between the $0 \mathrm{~cm}$ and $5 \mathrm{~cm}$ iButtons. It was assumed that the stream water was well mixed, so any sensor above the streambed recorded a temperature equal to that at the streambed interface. Thus, the $0 \mathrm{~cm}$ iButton recorded in-stream temperatures regardless of its position at or above the streambed. However, as scour removed streambed material above the $5 \mathrm{~cm}$, the effective distance between the $0 \mathrm{~cm}$ iButton and the $5 \mathrm{~cm}$ iButton decreased. Sensor spacings between the uppermost and middle iButtons roughly estimated at the time of removal ranged from $5 \mathrm{~cm}$ (the target) to $0 \mathrm{~cm}$; the $5 \mathrm{~cm}$ iButton downstream of Structure 7 was completely exposed effectively making the sensor spacing $0 \mathrm{~cm}$. Sensor spacing was not monitored during thermal data collection, so it is unknown when the changes occurred or if they occurred more than once. Shanafield et al. (2011) found that the Hatch et al. (2006) model accurately reproduced known velocities for fluxes greater than $1.5 \mathrm{~m} / \mathrm{d}(4.9 \mathrm{ft} / \mathrm{d})$ regardless of sensor spacing uncertainties, but a sensor spacing uncertainty of $20 \mathrm{~cm}(0.66 \mathrm{ft})$ consistently underestimated smaller fluxes. All fluxes determined in this study are smaller than $1.5 \mathrm{~m} / \mathrm{d}$, but the sensor spacing uncertainties were an order of magnitude smaller than that used by Shanafield et al. (2011). Thus, sensor spacing uncertainty should have a much smaller effect on fluxes in this study, but some error may still have been introduced. For future studies, all iButton installations should be below the streambed interface to eliminate this potential source of error.

It is likely that at least one assumption of the Stallman (1965) and Hatch et al. (2006) models (see "Heat Transport Modeling" section in Methods) was violated at this field site: purely vertical flow. The hydrometric data revealed that lateral gradients existed between the 
constructed channel and the adjacent wetland and pre-restoration channel. Additional nonvertical flow may have occurred through the streambed from upstream to downstream in largescale hyporheic cells (Figure 32). Lautz (2010) showed through numerical modeling that nonvertical flow is the greatest source of error in the Hatch et al. (2006) model. However, when non-vertical flow occurred, the Hatch et al. (2006) model delivered results within $20 \%$ of true fluxes and outperformed estimations of flux using hydrometric data. Despite the error induced by non-vertical flow, relative fluxes within a field site can be reliably compared to one another (Lautz, 2010). Thus, the flux results presented in this study should be considered relative to one another, with an understanding that error exists in absolute flux magnitude due to non-vertical flow. This error was not quantified by the Monte Carlo error analyses, which only considered uncertainties in thermal parameters. Non-vertical flow was not quantified in this study, but future work should include quantification and identification of non-vertical flow paths using MODFLOW flow modeling.

\section{Future Work}

A variety of future investigations could expand on the results of this study. The surficial materials at this site included thin alluvium, colluvium, historic pond deposits and off-site materials used during construction, which is a more complex suite of materials than a natural stream underlain by thick alluvium. Thus, detailed mapping of the heterogeneous surficial geology and characterization of the streambed and subsurface materials may help to explain hyporheic heterogeneities. Furthermore, the heat transport model results could be better constrained by quantifying the thermal parameters of the streambed via substrate analysis. 
Specifically, thermal conductivity, thermal diffusivity and volumetric heat capacity of the sediment should be determined via relations with bulk density (Lapham, 1989).

Results from the hydrometric data could be clarified by quantifying the hydraulic conductivity of the streambed via slug tests in the piezometers. Additionally, the hydrometric data could be used in numerical groundwater flow models to identify flow paths around the restoration structures or elaborate on the relationships between the constructed channel and the wetland or pre-restoration channel.

Conservative tracer experiments could be performed to meet several goals:

1) To determine the spatial extent of the hyporheic zone by measuring tracer concentrations in piezometers,

2) To confirm hydraulic connections between the constructed channel and the wetland or pre-restoration channel, and

3) To quantify residence time of stream water in the subsurface, which would have implications for hyporheic functions, such as biogeochemical cycling.

If the hydraulic disconnection between the stream and the subsurface is a product of restoration, then hydraulic connections may evolve with time. Any of the methods described above could be repeated in five, ten or more years to assess the long-term evolution of the hyporheic zone.

\section{Implications of Results for Future Studies}

The complexity of this study's results is a testament to the heterogeneous nature of restored and constructed channels - the sparse instrumentation network at Savage River did not adequately characterize heterogeneous hyporheic patterns. Constructed and restored channels 
are likely to be more heterogeneous than natural channels due to the absence of natural fluvial sorting of subsurface materials at disturbed sites. Future post-restoration study designs must account for this heterogeneity by implementing denser instrumentation networks and by thoroughly characterizing subsurface material properties. In circumstances where resources are limited, a better approach than that taken in this study may be to focus all instrumentation on a single restoration structure in order to document heterogeneities at the channel unit scale.

Hester and Gooseff (2010) suggested that restoration designs should incorporate channel elements that promote hyporheic exchange to enhance ecosystem function, and Daniluk et al. (2012) showed that restoration structures do enhance hyporheic exchange fluxes compared to reference sites. The flux results from this study, however, contrast those of Daniluk et al. (2012), showing no difference in flux magnitudes between the constructed channel and the reference riffle. Unfortunately, most post-restoration hyporheic studies to date have not compared their results to reference streams, so it is difficult to assess impacts on hyporheic exchange due to restoration activities when two conflicting studies exist. Future studies should incorporate both relatively undisturbed "natural" reference sites and unrestored degraded sites to assess functional improvements to the hyporheic zone resulting solely from restoration activities. An ideal study design would include hyporheic data collection on a degraded stream before restoration, on the same stream after restoration, and on the reference reach(es) used for the restoration design. A study of this nature would not only allow for assessment of hyporheic functional lift due to restoration, but also would allow observations of materials and processes used in construction to better characterize the subsurface materials.

Post-restoration studies can provide useful information to practitioners regarding the impact of in-stream restoration structures on hyporheic function. As Gordon et al. (in press) 
showed, structure-induced downwelling or upwelling does not necessarily correlate to enhanced hyporheic function at the reach-scale. Biogeochemical cycling is an important hyporheic function that structures could potentially enhance, so increasing residence time and the extent of biogeochemical reactions in the hyporheic zone may commonly be desirable outcomes of restoration. Thus, future post-restoration studies should also incorporate assessment of residence time, biogeochemical conditions in the hyporheic zone, and the cumulative impact of those conditions on water quality and ecosystem health. By filling these voids in restoration science, practitioners will be better equipped to design future restoration projects for maximum ecological benefit.

\section{References}

Amsden, TW, Overbeck, RM, Martin, RO, 1954. Geology and Water Resources of Garrett County: Maryland Department of Geology, Mines and Water Resources Bulletin 13, 1116.

Bernhardt, ES, Palmer, MA, Allan, JD, Alexander, G, Barnas, K, Brooks, S, Carr, J, Clayton, S, Dahm, C, Follstad-Shah, J, Galat, D, Gloss, S, Goodwin, P, Hart, D, Hasset, B, Jenkinson, R, Katz, S, Kondolf, GM, Lake, PS, Lave, R, Meyer, JL, O’Donnell, TK, Pagano, L, Powell, B, Sudduth, E, 2005. Synthesizing US River Restoration Efforts: Science, vol. 308, 636-637.

Bernhardt, ES, Sudduth, EB, Palmer, MA, Allan, JD, Meyer, JL, Alexander, G, Follstad-Shah, J, Hasset, B, Jenkinson, R, Lave, R, Rumps, J, Pagano, L, 2007. Restoring Rivers One Reach at a Time: Results from a Survey of US River Restoration Practitioners:

Restoration Ecology, vol. 15, no. 3, 482-493.

Brezinski, DK, 1988. Geologic Map of the Avilton and Frostburg Quadrangles, Maryland: Maryland Geological Survey, scale 1:24000, 1 sheet.

Briggs, MA, Lautz, LK, McKenzie, JM, Gordon, RP, Hare, DK, 2012. Using high-resolution distributed temperature sensing to quantify spatial and temporal variability in vertical hyporheic flux: Water Resources Research, vol. 48, W02527, 16 p. 
Buffington, JM, Tonina, D, 2009. Hyporheic exchange in mountain rivers II: Effects of channel morphology on mechanics, scales and rates of exchange: Geography Compass, vol. 3, no. 3, 1038-1062.

Bunte, K, Abt, SR, 2001. Sampling Surface and Subsurface Particle-Size Distributions in Wadable Gravel- and Cobble- Bed Streams for Analyses in Sediment Transport, Hydraulics and Streambed Monitoring: USDA Forest Service General Technical Report RMRS-GTR-74, 104.

Crispell, JK, Endreny, TA, 2009. Hyporheic exchange flow around constructed in-channel structures and implications for restoration design: Hydrological Processes, vol. 23, no. 8, 1158-1168.

Daniluk, TL, Lautz, LK, Gordon, RP, Endreny, TA, 2012. Surface water-groundwater interaction at restored streams and associated reference reaches: Hydrological Processes, doi: 10.1002/hyp.9501.

Dicken, CL, Nicholson, SW, Horton, JD, Kinney, SA, Gunther, G, Foose, MP, Mueller, JAL, 2005. Integrated Geologic Map Databases for the United States: Delaware, Maryland, New York, Pennsylvania, and Virginia: U.S. Geological Survey Open-File Report 20051325, U.S. Geological Survey, Reston, VA.

Fenneman, NM, 1928. Physiographic Divisions of the United States: Annals of the Association of American Geographers, vol. 18, no. 4, 95 p.

Findlay, S, 1995. Importance of surface-subsurface exchange in stream ecosystems: The hyporheic zone: Limnology and Oceanography, vol. 40, no. 1, 159-164.

Gordon, RP, Lautz, LK, Briggs, MA, McKenzie, JM, 2012. Automated calculation of vertical pore-water flux from field temperature time series using the VFLUX method and computer program: Journal of Hydrology, vol. 420-421, 142-158.

Gordon, RP, Lautz, LK, Daniluk, TL, in press. Spatial patterns of hyporheic exchange and biogeochemical cycling around cross-vane restoration structures: The role of the hyporheic zone and implications for stream restoration design: Water Resources Research, doi: 10.1002/wrcr.20185.

Harvey, JW, Bencala, KE, 1993. The Effect of Streambed Topography on SurfaceSubsurface Water Exchange in Mountain Catchments: Water Resources Research, vol. 29, no. 1, 89-98.

Hasset, B, Palmer, M, Bernhardt, E, Smith, S, Carr, J, Hart, D, 2005. Restoring watersheds project by project: trends in Chesapeake Bay tributary restoration: Frontiers in Ecology and the Environment, vol. 3, no. 5, 259-267. 
Hatch, CE, Fisher, AT, Revenaugh, JS, Constantz, J, Ruehl, C, 2006. Quantifying surface watergroundwater interactions using time series analysis of streambed thermal records: method development: Water Resources Research, vol. 42, W10410, 14 p.

Hester, ET, Doyle, MW, 2008. In-stream geomorphic structures as drivers of hyporheic exchange: Water Resources Research, vol. 44, W03417, 17 p.

Hester, ET, Gooseff, MN, 2010. Moving beyond the banks: hyporheic restoration is fundamental to restoring ecological services and functions of streams: Environmental Science and Technology, vol. 44, 1521-1525.

Kasahara, T, Wondzell, SM, 2003. Geomorphic controls on hyporheic exchange flow in mountain streams: Water Resources Research, vol. 39, no. 1, 1005.

Kasahara, T, Hill, AR, 2008. Modeling the effects of lowland stream restoration projects on stream-subsurface water exchange: Ecological Engineering, vol. 32, 310-319.

Kondolf, GM, Smeltzer, MW, Railsback, SF, 2001. Design and Performance of a Channel Reconstruction Project in a Coastal California Gravel-bed Stream: Environmental Management, vol. 28, no. 6, 761-776.

Kresic, N, 1997. Quantitative Solutions in Hydrogeology and Groundwater Modeling: New York: Lewis Publishers, 362-363.

Lapham, WW, 1989. Use of temperature profiles beneath streams to determine rates of vertical ground-water flow and vertical hydraulic conductivity: USGS Water-Supply Paper 2337, $35 \mathrm{p}$.

Lautz, LK, 2010. Impacts of nonideal field conditions on vertical water velocity estimates from streambed temperature time series: Water Resources Research, vol. 46, W01509, 14 p.

Lautz, LK, Kranes, NT, Siegel, DI, 2010. Heat tracing of heterogeneous hyporheic exchange adjacent to in-stream geomorphic features: Hydrological Processes, vol. 24, no. 21, 30743086.

Lave, R, 2008.The Rosgen Wars and the Shifting Political Economy of Expertise: PhD Dissertation, University of California, Berkeley, $251 \mathrm{p}$.

Lave, R, 2009. The Controversy Over Natural Channel Design: Substantive Explanations and Potential Avenues for Resolution: Journal of the American Water Resources Association, vol. 45, no. 6, 1519-1532.

Lave, R, Doyle, M, Robertson, M, 2010. Privatizing stream restoration in the US: Social Studies of Science, vol. 40.5, 677-703. 
Nutter, LJ, Smigaj, MJ, Knobel, LL, 1980. Garrett County Water-Well Records, Chemical Quality Data, Groundwater Use, Coal Test-hole Data and Surface-Water Data: Maryland Geological Survey Basic Data Report Number 11, 102 p.

Postlethwait, W, 2010a. Frostburg Reservoir Dam Removal Project Headwaters of the Savage River Garrett County, MD (Updated Design): Canaan Valley Institute, 33p.

Postlethwait, W, 2010b. Frostburg Reservoir Dam Removal Project Headwaters of the Savage River Garrett County, MD (As Built): Canaan Valley Institute, 17p.

Postlethwait, W, 2011. Written communication to Anna Berlinghieri.

Rosgen, DL, 1994. A classification of natural rivers: Catena, vol. 22, 169-199.

Rosgen, DL, 2006. The Cross-Vane, W-Weir and J-hook Vane Structures and their Description, Design and Application for Stream Stabilization and River Restoration: Wildland Hydrology, Inc, 22 p.

Savant, SA, Reible, DD, Thibodeaux, LJ, 1987. Convective transport within stable river sediments: Water Resources Research, vol. 23, 1763-1768.

Shanafield, M, Hatch, C, Pohll, G, 2011. Uncertainty in thermal time series analysis estimates of streambed water flux: Water Resources Research, vol. 47, W03504, 7 p.

Shanafield, M, Cook, PG, Brunner, P, McCallum, J, Simmons, CT, 2012. Aquifer response to surface water transcience in disconnected streams: Water Resources Research, vol. 48, W11510, 8 p.

Stallman, RW, 1965. Steady One-Dimensional Fluid Flow in a Semi-Infinite Porous Medium with Sinusoidal Surface Temperature: Journal of Geophysical Research, vol. 70, no. 12, 2821-2827.

Stanford, JA, Ward, JV, 1988. The hyporheic habitat of river ecosystems: Nature, vol. 335, 6466.

Stanford, JA, Ward, JV, 1993. An ecosystem perspective of alluvial rivers: connectivity and the hyporheic corridor: Journal of the North American Benthological Society, vol. 12, no. 1, 48-60.

Stonestrom, DA, Blasch, KW, 2003. Determining Temperature and Thermal Properites for Heatbased Studies of Surface-water Ground-water Interactions in Stonestrom, DA, Constantz, J, eds, Heat as a Tool for Studying the Movement of Ground Water Near Streams: US Department of the Interior United States Geological Survey, no. 1260, 169-188. 
Stonestrom, DA, Constantz, J, 2003. Heat as a Tool for Studying the Movement of Ground Water Near Streams: US Department of the Interior United States Geological Survey, no. $1260,1-7$.

Wohl, E, Angermeier, PL, Bledsoe, B, Kondolf, GM, MacDonnell, L, Merritt, DM, Palmer, MA, Poff, NL, Tarboton, D, 2005. River Restoration: Water Resources Research, vol. 41, W10301, 12 p.

Wondzell, SM, Swanson, FJ, 1996. Seasonal and storm dynamics of the hyporheic zone of a $4^{\text {th }}$ order mountain stream I: Hydrologic processes: Journal of North American Benthological Society, vol. 15, no. 1, 3-19.

Wondzell, SM, Swanson, FJ, 1999. Floods, channel change and the hyporheic zone: Water Resources Research, vol. 35, no. 2, 555-567.

Wroblicky, GJ, Campana, ME, Valett, HM, Dahm, CN, 1998. Seasonal variation in surfacesubsurface water exchange and lateral hyporheic area of two stream-aquifer systems: Water Resources Research, vol. 34, no. 3, 317-328.

Young, PC, Pedregal, DJ, Tych, W, 2010. Dynamic Harmonic Regression: Journal of Forecasting, vol. 18, 369-394. 


\section{Appendix A: Additional Hydrometric Data}

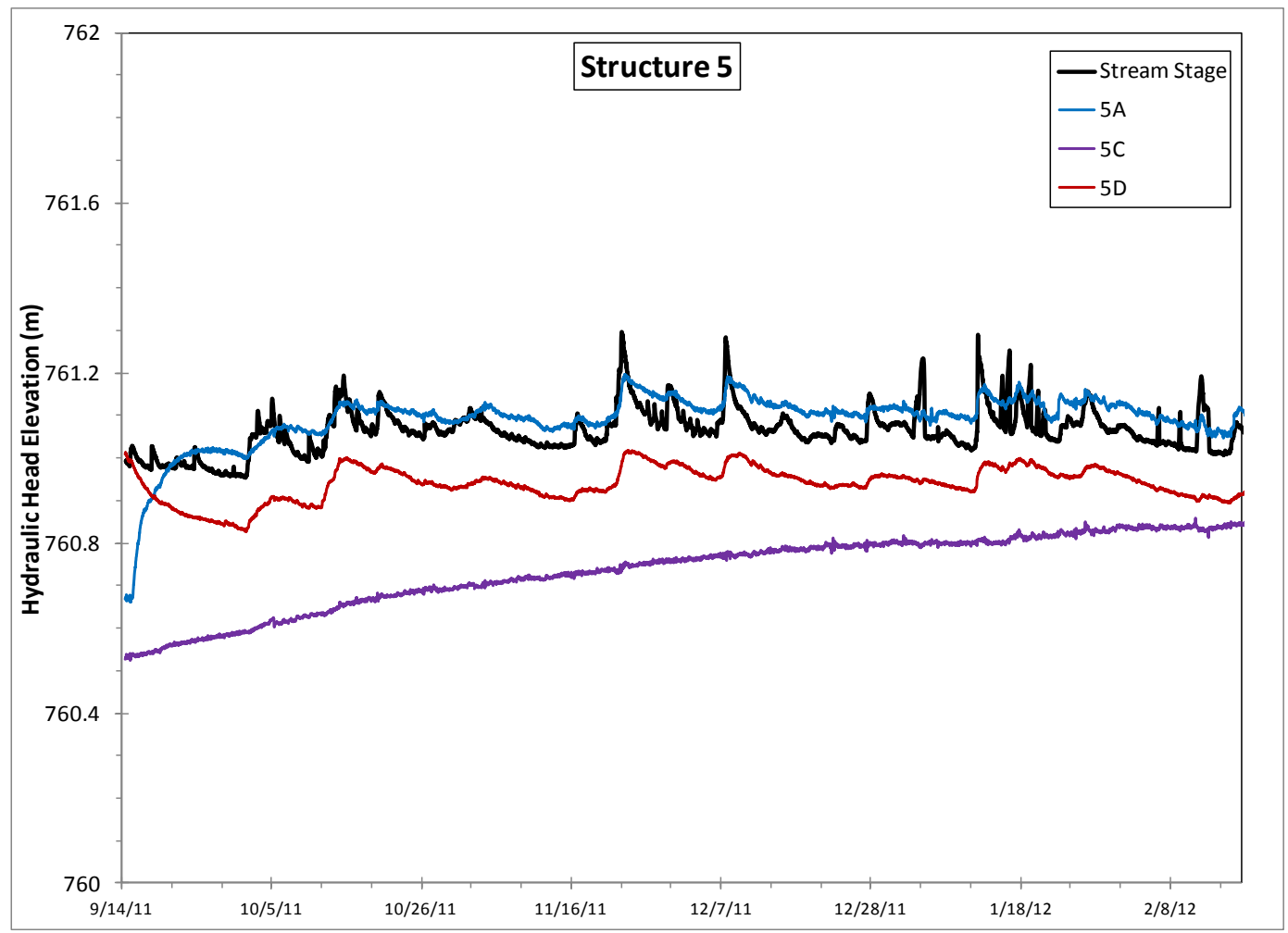

Figure A1: Hydrometric data from Structure 5 for 14 September 2011 to 18 February 2012.

Stream stage was collected at Structure 6 and extrapolated to Structure 5 using the water level differences in the longitudinal profile. 


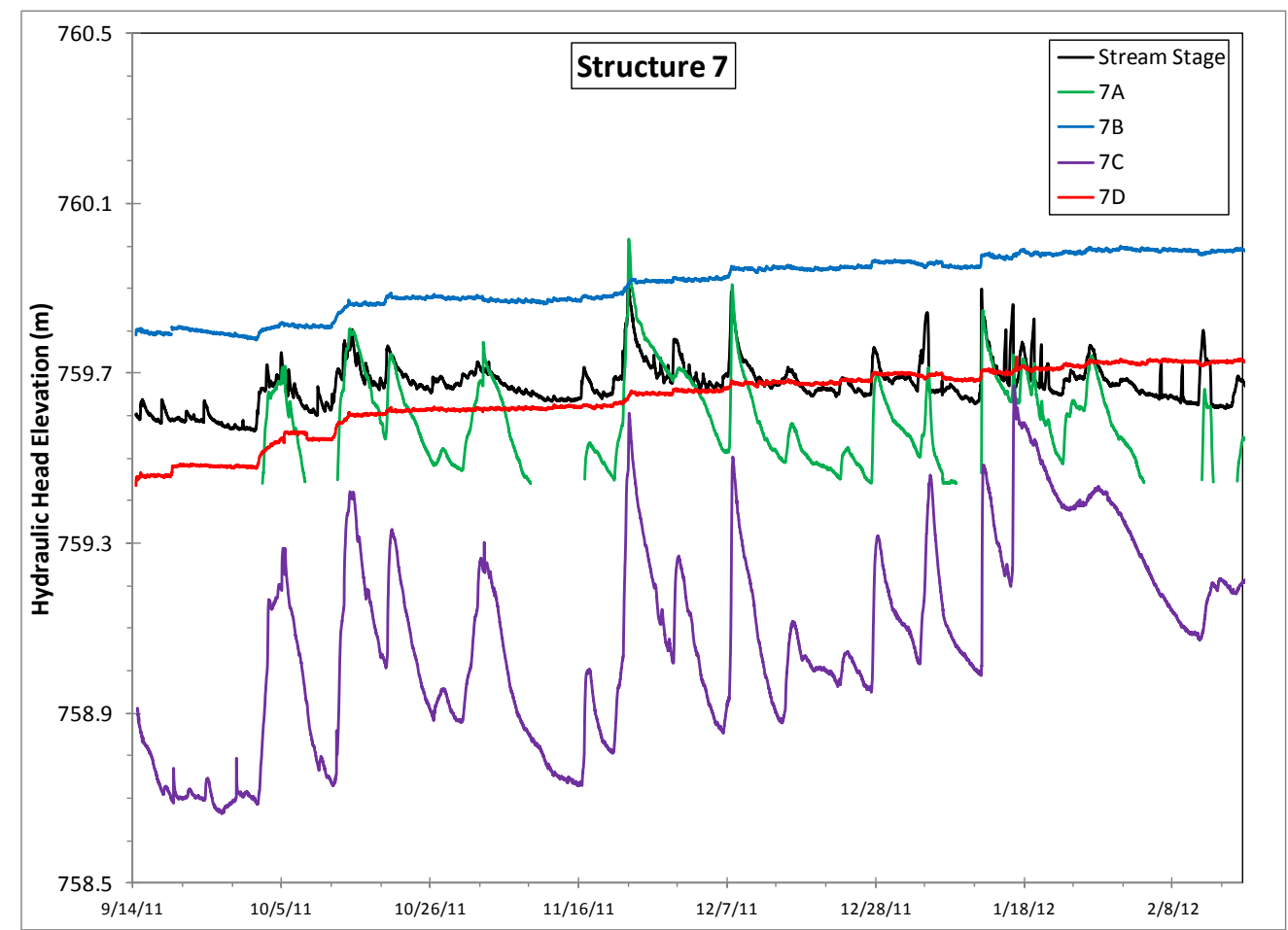

Figure A2: Hydrometric data from Structure 7 for 14 September 2011 to 18 February 2012. Stream stage was collected at Structure 6 and extrapolated to Structure 7 using the water level differences in the longitudinal profile. The gaps in data for 7A indicate that this piezometer was dry during these time periods.

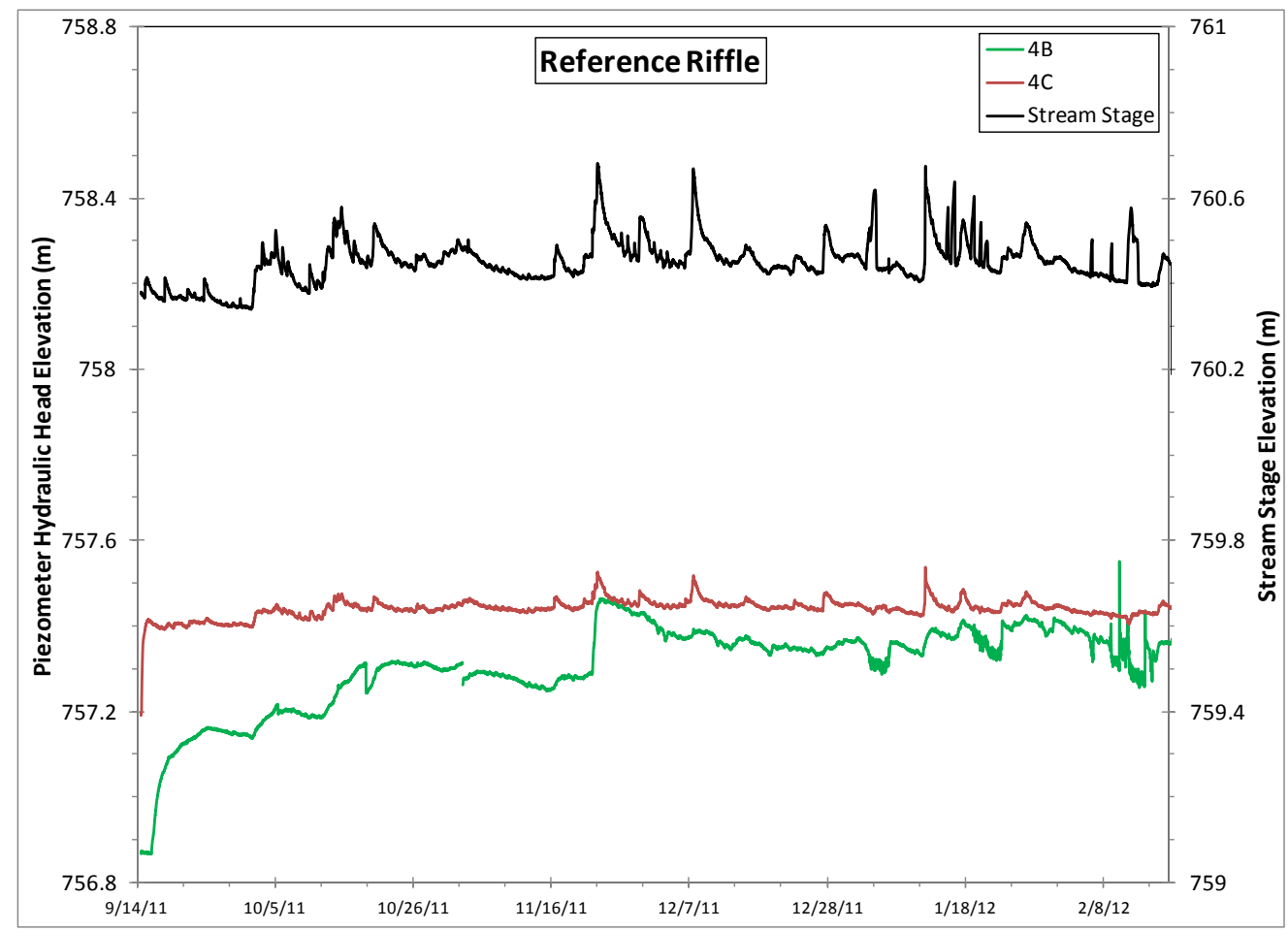

Figure A3: Hydrometric data from reference riffle for 14 September 2011 to 18 February 2012. Stream stage (right axis) was collected at Structure 6. 


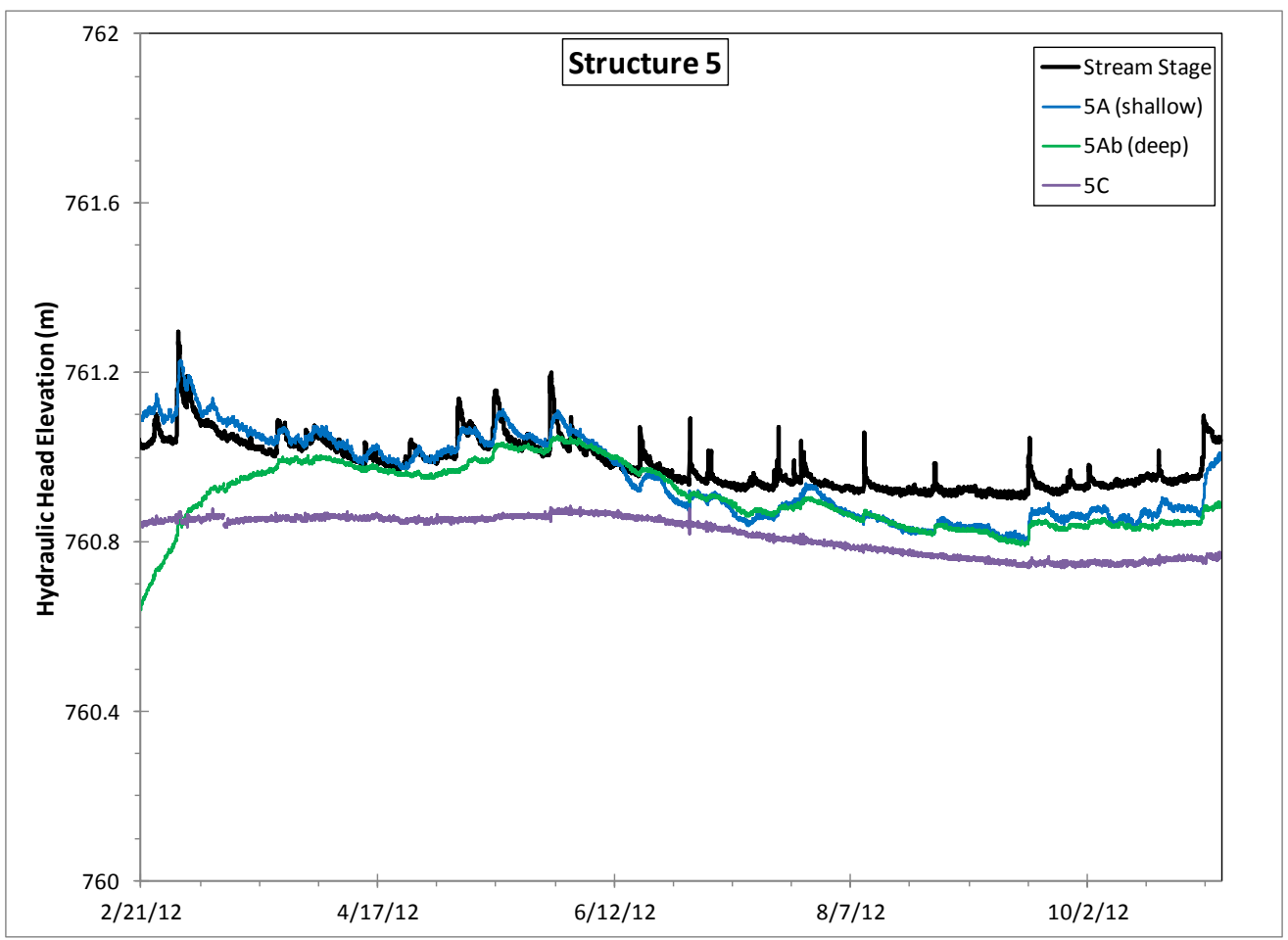

Figure A4: Hydrometric data from Structure 5 for 21 February to 2 November 2012.

Stream stage was collected at Structure 6 and extrapolated to Structure 5 using the water level differences in the longitudinal profile.

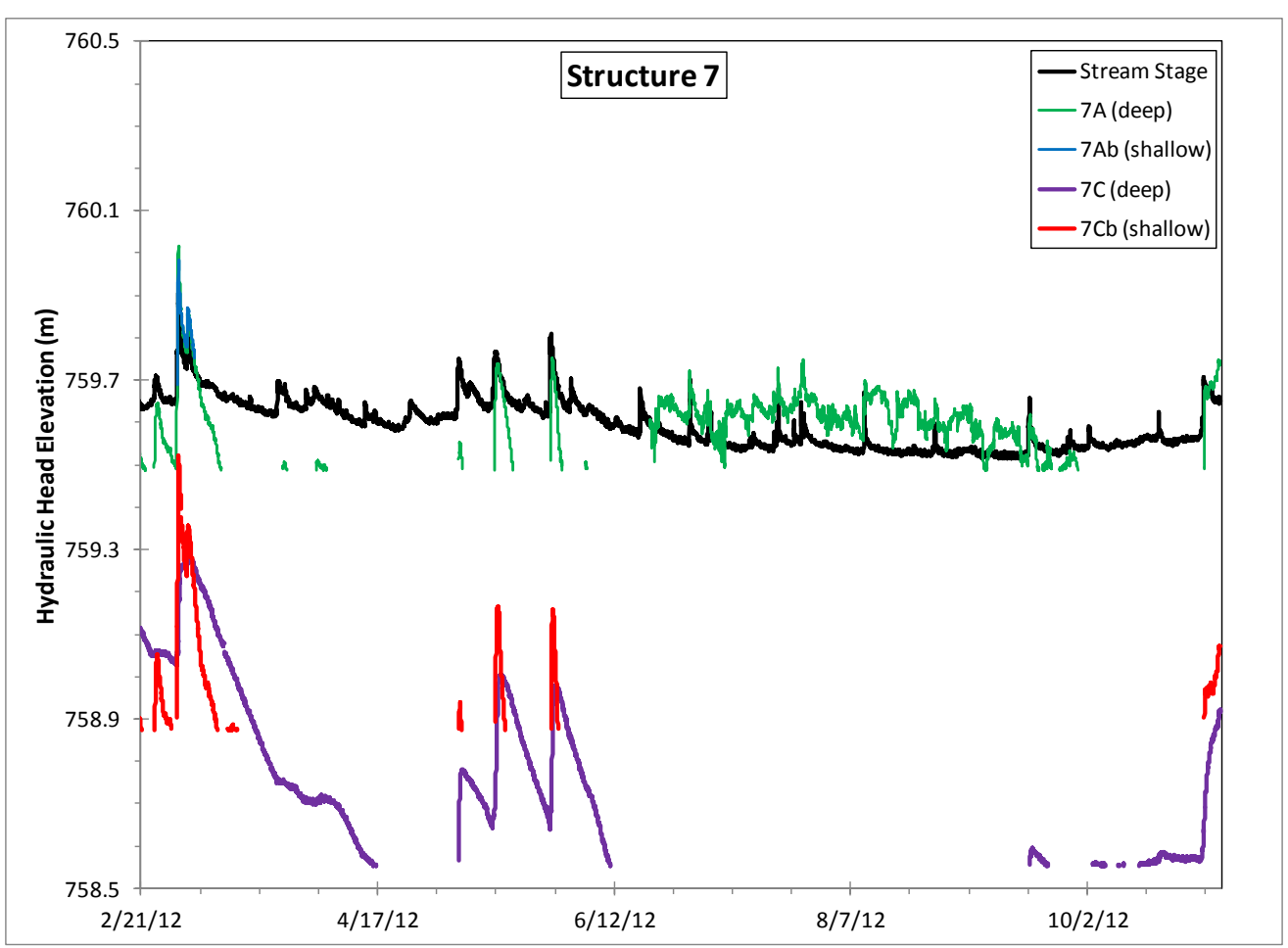

Figure A5: Hydrometric data from Structure 7 for 21 February to 2 November 2012. Stream stage was collected at Structure 6 and translated to Structure 7 using the water level differences in the longitudinal profile. The gaps in data indicate that these piezometers were dry during these time periods. 


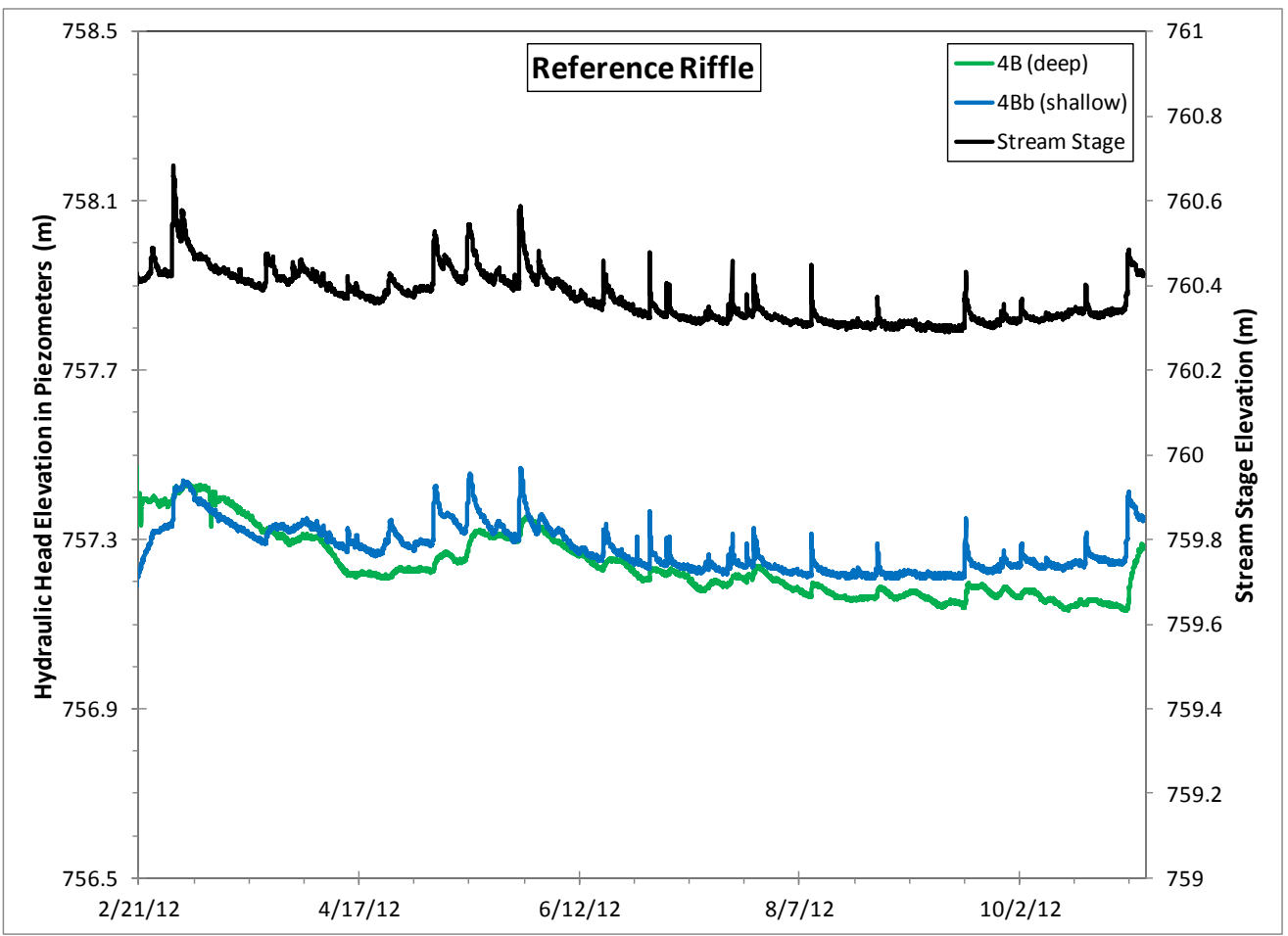

Figure A6: Hydrometric data from reference riffle for 21 February to 2 November 2012. Stream stage (right axis) was collected at Structure 6. 


\section{Appendix B: Rating Curve}

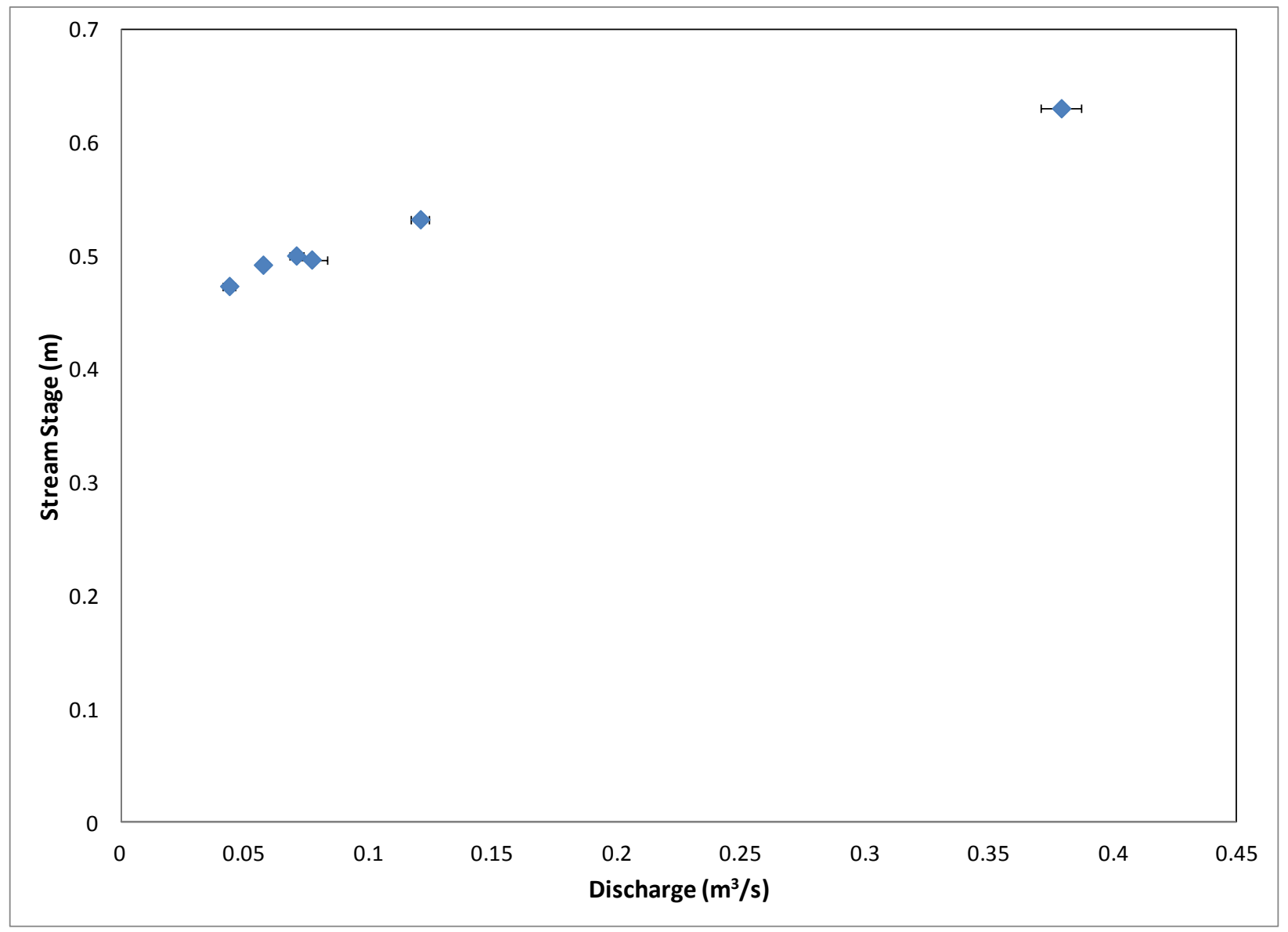

Figure B1: Relationship between stream stage and discharge for gage downstream of Structure 6 . Error bars indicate standard deviation of 3 discharge measurements taken for each stream stage. 


\section{Appendix C: Manual Water Level Measurements and Hydraulic Gradients}

Table C1a: Hydraulic heads measured manually on 2 March 2012. Column ' $D$ ' indicates installation depth for nested piezometers, where ' $\mathrm{S}$ ' is the shallow piezometer and ' $\mathrm{D}$ ' is the deeper piezometer.

\begin{tabular}{|c|c|c|c|c|}
\hline Date & Time & Piezometer & D & $\operatorname{Head}(\mathrm{m})$ \\
\hline $3 / 2 / 2012$ & $1: 30 \mathrm{PM}$ & $5 A$ & $\mathrm{~S}$ & 761.192 \\
\hline $3 / 2 / 2012$ & 1:31 PM & $5 A b$ & $\mathrm{D}$ & 760.760 \\
\hline $3 / 2 / 2012$ & 1:34 PM & $5 B$ & & 761.093 \\
\hline $3 / 2 / 2012$ & $1: 35$ PM & $5 C$ & $\mathrm{D}$ & 760.807 \\
\hline $3 / 2 / 2012$ & 1:36 PM & $5 \mathrm{Cb}$ & $\mathrm{S}$ & 761.154 \\
\hline $3 / 2 / 2012$ & 1:40 PM & $5 D$ & & 761.082 \\
\hline $3 / 2 / 2012$ & 1:41 PM & $6 \mathrm{~A}$ & $\mathrm{~S}$ & 760.184 \\
\hline $3 / 2 / 2012$ & $1: 42$ PM & $6 A b$ & $\mathrm{D}$ & 760.246 \\
\hline $3 / 2 / 2012$ & 1:45 PM & $6 B$ & $\mathrm{~S}$ & 760.097 \\
\hline $3 / 2 / 2012$ & $1: 46 \mathrm{PM}$ & $6 \mathrm{Bb}$ & $D$ & 760.150 \\
\hline $3 / 2 / 2012$ & 1:48 PM & $6 C$ & & 760.253 \\
\hline $3 / 2 / 2012$ & $1: 49$ PM & $6 D$ & & 760.939 \\
\hline $3 / 2 / 2012$ & 1:50 PM & $6 \mathrm{E}$ & & 761.105 \\
\hline $3 / 2 / 2012$ & 1:54 PM & $7 \mathrm{~A}$ & D & 759.820 \\
\hline $3 / 2 / 2012$ & $1: 55$ PM & $7 \mathrm{Ab}$ & $\mathrm{S}$ & 759.845 \\
\hline $3 / 2 / 2012$ & $1: 58 \mathrm{PM}$ & $7 \mathrm{~B}$ & & 760.004 \\
\hline $3 / 2 / 2012$ & 1:59 PM & $7 C$ & $D$ & 759.234 \\
\hline $3 / 2 / 2012$ & 2:00 PM & $7 \mathrm{Cb}$ & $\mathrm{S}$ & 759.374 \\
\hline $3 / 2 / 2012$ & 2:02 PM & $7 D$ & & 759.679 \\
\hline $3 / 2 / 2012$ & 2:03 PM & 7E & & 759.960 \\
\hline $3 / 2 / 2012$ & 2:12 PM & $4 \mathrm{~A}$ & & 757.625 \\
\hline $3 / 2 / 2012$ & 2:08 PM & $4 B$ & $\mathrm{D}$ & 757.406 \\
\hline $3 / 2 / 2012$ & 2:09 PM & $4 \mathrm{Bb}$ & $\mathrm{S}$ & 757.411 \\
\hline $3 / 2 / 2012$ & 2:07 PM & $4 C$ & & 757.587 \\
\hline $3 / 2 / 2012$ & 2:05 PM & 4Da & & 758.196 \\
\hline $3 / 2 / 2012$ & $1: 43$ PM & Stage & & 760.437 \\
\hline $3 / 2 / 2012$ & $1: 28 \mathrm{PM}$ & W & & 761.606 \\
\hline
\end{tabular}

Table C1b: Hydraulic heads measured manually on 11 March 2012. Column ' $D$ ' indicates installation depth for nested piezometers, where ' $\mathrm{S}$ ' is the shallow piezometer and ' $\mathrm{D}$ ' is the deeper piezometer.

\begin{tabular}{|c|c|c|c|c|}
\hline Date & Time & Piezometer & D & Head (m) \\
\hline $3 / 11 / 2012$ & 4:28 PM & $5 \mathrm{~A}$ & $\mathrm{~S}$ & 761.079 \\
\hline $3 / 11 / 2012$ & 4:29 PM & $5 \mathrm{Ab}$ & $\mathrm{D}$ & 760.849 \\
\hline $3 / 11 / 2012$ & 4:31 PM & $5 B$ & & 761.071 \\
\hline $3 / 11 / 2012$ & 4:32 PM & $5 C$ & $D$ & 760.815 \\
\hline $3 / 11 / 2012$ & 4:33 PM & $5 \mathrm{Cb}$ & $\mathrm{S}$ & 761.024 \\
\hline $3 / 11 / 2012$ & 4:36 PM & $5 \mathrm{D}$ & & 761.033 \\
\hline $3 / 11 / 2012$ & 4:37 PM & $6 \mathrm{~A}$ & $\mathrm{~s}$ & 759.923 \\
\hline 3/11/2012 & 4:38 PM & $6 \mathrm{Ab}$ & $\mathrm{D}$ & 759.868 \\
\hline $3 / 11 / 2012$ & 4:40 PM & $6 \mathrm{~B}$ & $\mathrm{~s}$ & 759.716 \\
\hline $3 / 11 / 2012$ & 4:40 PM & $6 \mathrm{Bb}$ & $\mathrm{D}$ & 759.788 \\
\hline $3 / 11 / 2012$ & 4:41 PM & $6 C$ & & 760.244 \\
\hline $3 / 11 / 2012$ & 4:42 PM & $6 \mathrm{D}$ & & 760.965 \\
\hline $3 / 11 / 2012$ & 4:44 PM & $6 \mathrm{E}$ & & 761.120 \\
\hline $3 / 11 / 2012$ & 4:45 PM & $7 \mathrm{~A}$ & $\mathrm{D}$ & 759.415 \\
\hline $3 / 11 / 2012$ & 4:46 PM & $7 \mathrm{Ab}$ & $\mathrm{S}$ & dry \\
\hline $3 / 11 / 2012$ & 4:47 PM & $7 \mathrm{~B}$ & & 760.020 \\
\hline $3 / 11 / 2012$ & 4:49 PM & $7 C$ & $\mathrm{D}$ & 759.040 \\
\hline $3 / 11 / 2012$ & 4:50 PM & $7 \mathrm{Cb}$ & $\mathrm{S}$ & 758.792 \\
\hline $3 / 11 / 2012$ & 4:53 PM & $7 \mathrm{D}$ & & 759.699 \\
\hline $3 / 11 / 2012$ & 4:54 PM & $7 \mathrm{E}$ & & 759.979 \\
\hline $3 / 11 / 2012$ & 5:02 PM & $4 \mathrm{~A}$ & & 757.637 \\
\hline $3 / 11 / 2012$ & 4:59 PM & $4 \mathrm{~B}$ & $\mathrm{D}$ & 757.395 \\
\hline $3 / 11 / 2012$ & 5:00 PM & $4 \mathrm{Bb}$ & $\mathrm{s}$ & 757.357 \\
\hline $3 / 11 / 2012$ & 4:58 PM & $4 C$ & & 757.539 \\
\hline $3 / 11 / 2012$ & 4:56 PM & $4 \mathrm{Da}$ & & 758.202 \\
\hline $3 / 11 / 2012$ & 5:05 PM & Stage & & 760.312 \\
\hline $3 / 11 / 2012$ & 4:26 PM & W & & 761.683 \\
\hline
\end{tabular}


Table C2: Vertical hydraulic gradients for in-stream pairs of nested piezometers. Determined from manual water level measurements taken twice during study period.

\begin{tabular}{|l|r|r|}
\cline { 2 - 3 } & \multicolumn{2}{|c|}{ Vertical Hydraulic Gradient (m/m) } \\
\cline { 2 - 3 } & $\mathbf{3 / 2 / 2 0 1 2}$ & $\mathbf{3 / 1 1 / 2 0 1 2}$ \\
\hline Upstream of Structure 5 & 2.877 & 1.530 \\
\hline Downstream of Structure 5 & 4.401 & 2.661 \\
\hline Upstream of Structure 6 & -2.774 & 2.459 \\
\hline Downstream of Structure 6 & -0.707 & -0.973 \\
\hline Upstream of Structure 7 & 0.396 & $\mathrm{n} / \mathrm{a}$ \\
\hline Downstream of Structure 7 & 1.875 & -3.334 \\
\hline Reference Riffle & 0.084 & -0.563 \\
\hline
\end{tabular}




\section{Appendix D: Thermal Data and Volumetric Water Flux Results}

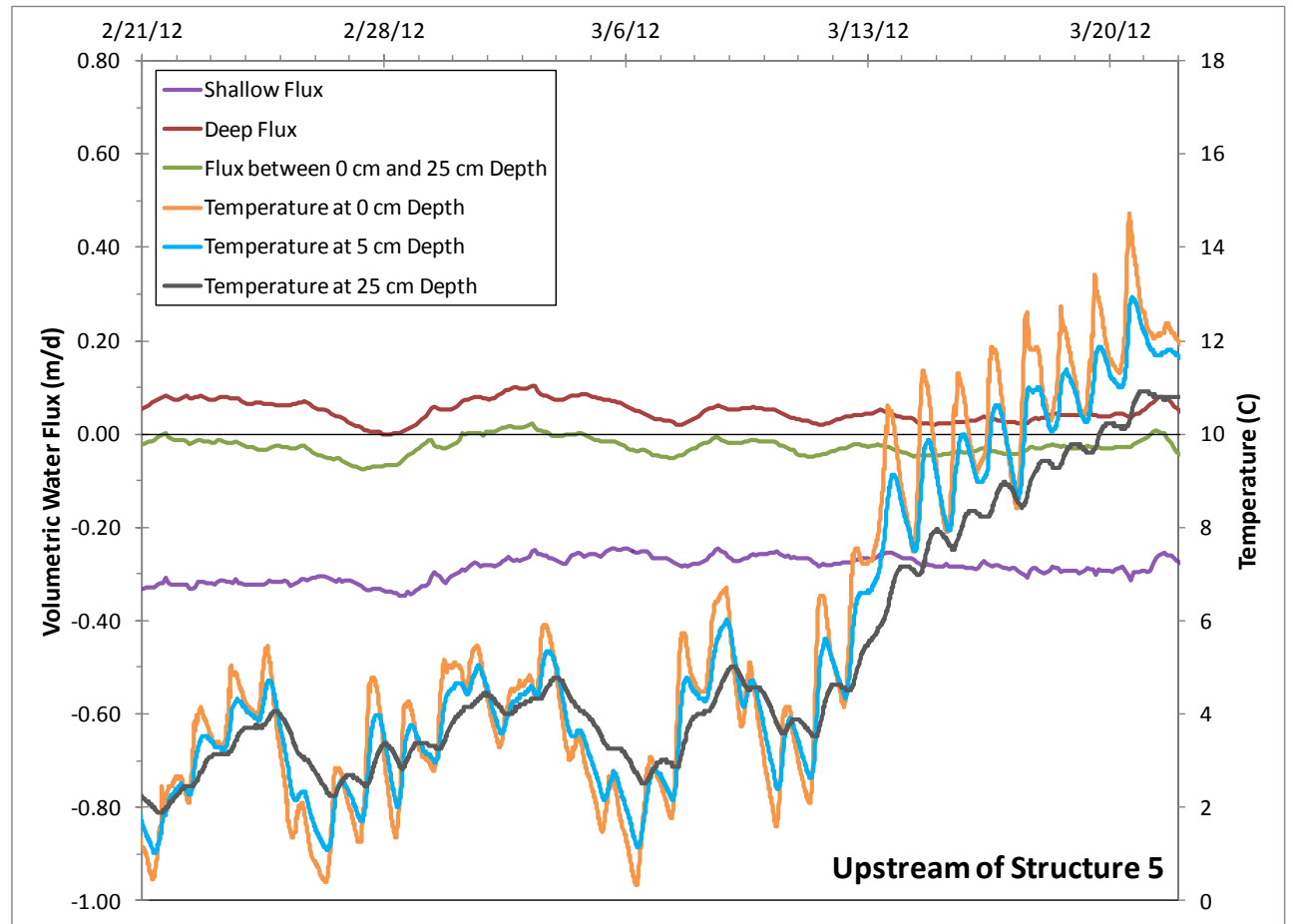

Figure D1: Temperature time series for 3 iButtons and hyporheic fluxes upstream of Structure 5. Positive flux values indicate downwelling, and the horizontal line at zero represents static flux.

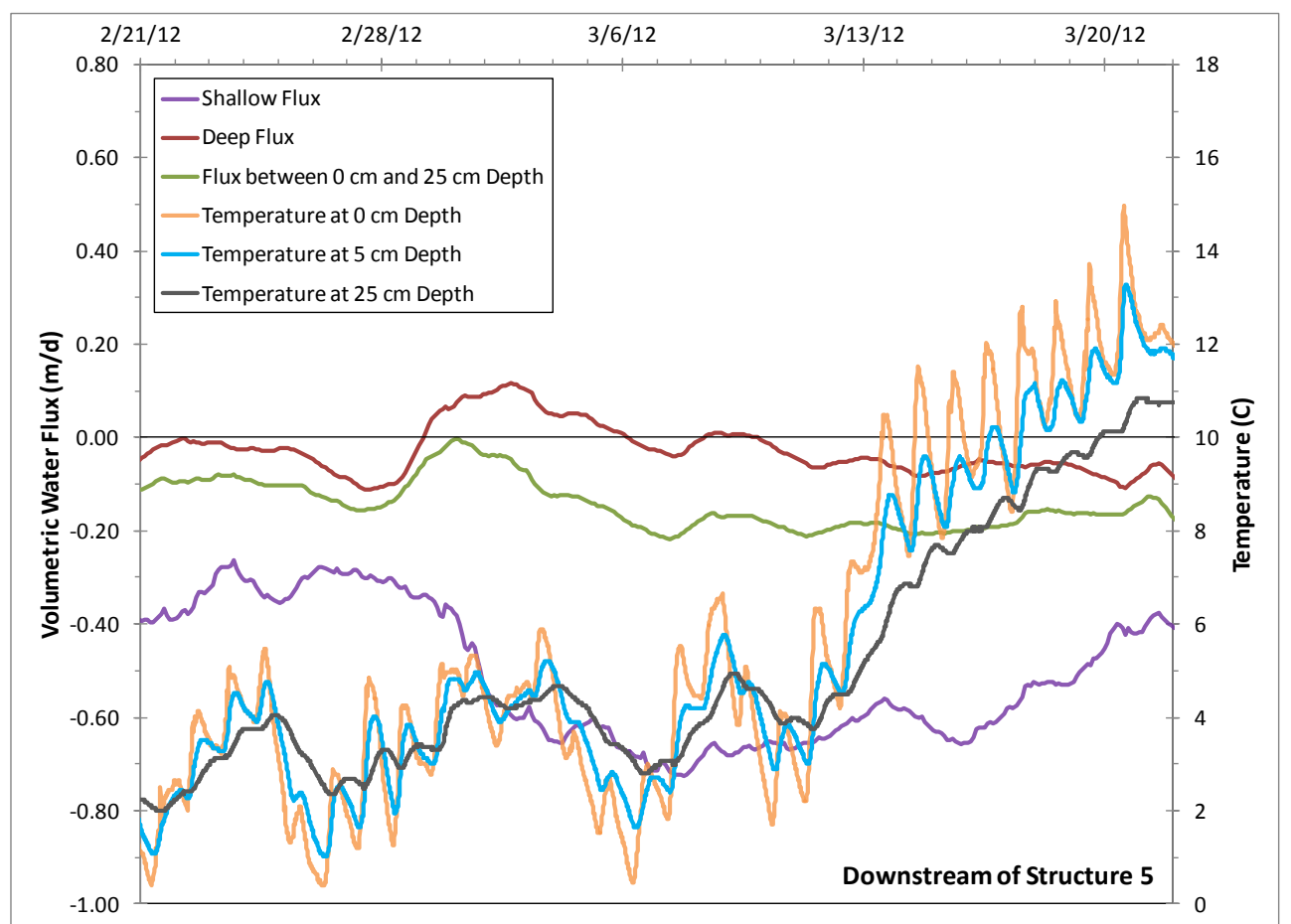

Figure D2: Temperature time series for 3 iButtons and hyporheic fluxes downstream of Structure 5. Positive flux values indicate downwelling, and the horizontal line at zero represents static flux. 


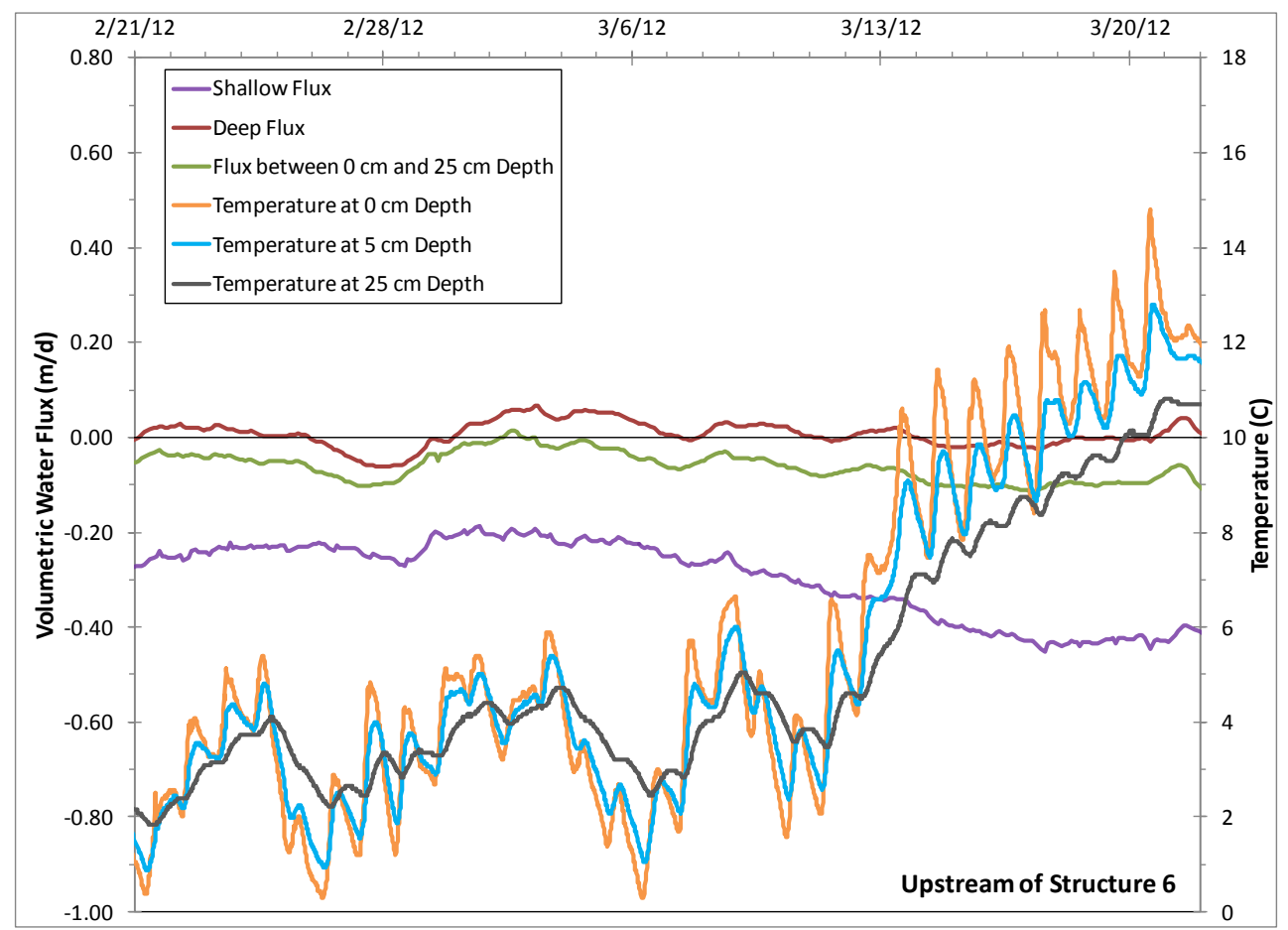

Figure D3: Temperature time series for 3 iButtons and hyporheic fluxes upstream of Structure 6. Positive flux values indicate downwelling, and the horizontal line at zero represents static flux.

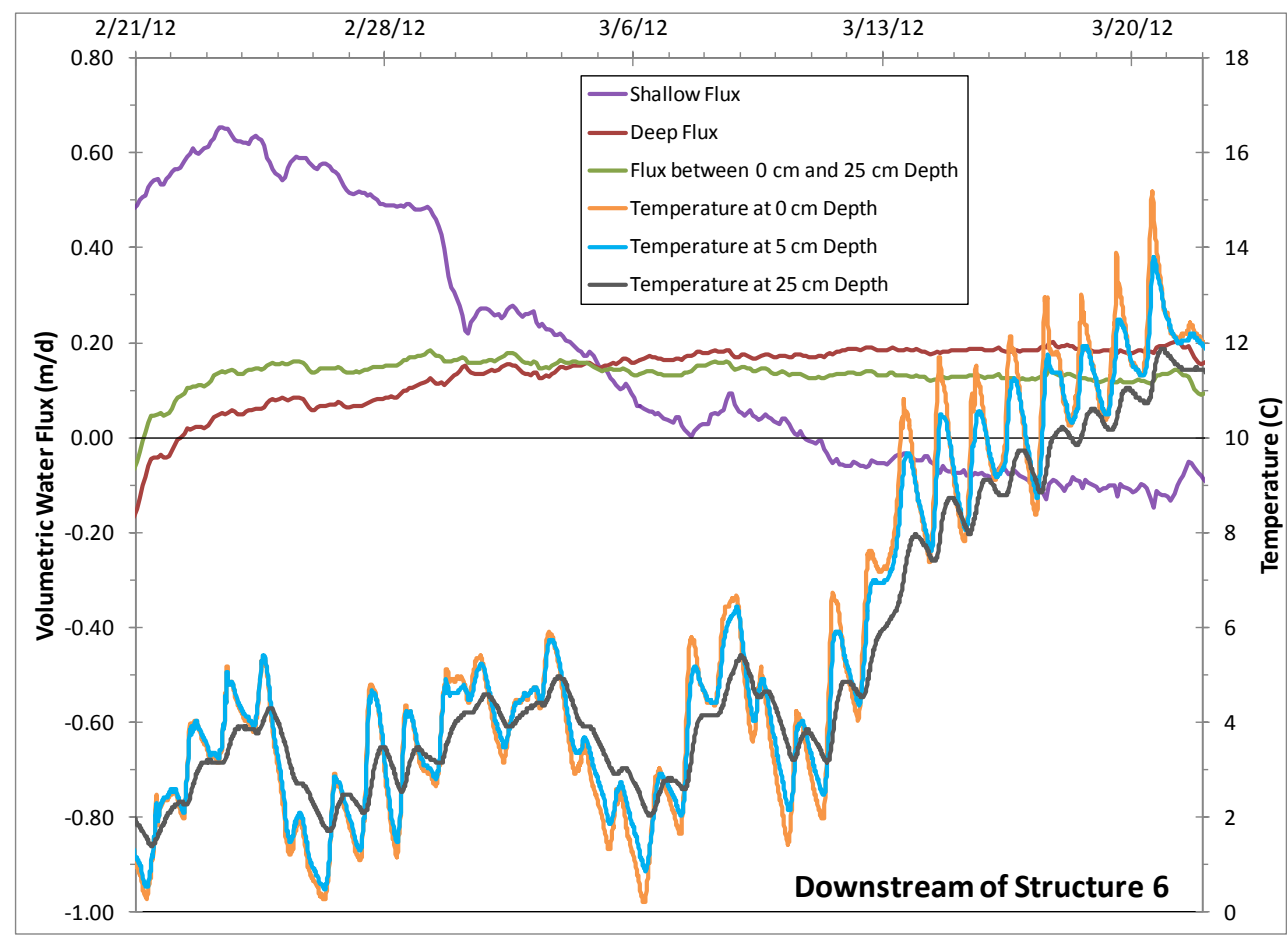

Figure D4: Temperature time series for 3 iButtons and hyporheic fluxes downstream of Structure 6. Positive flux values indicate downwelling, and the horizontal line at zero represents static flux. 


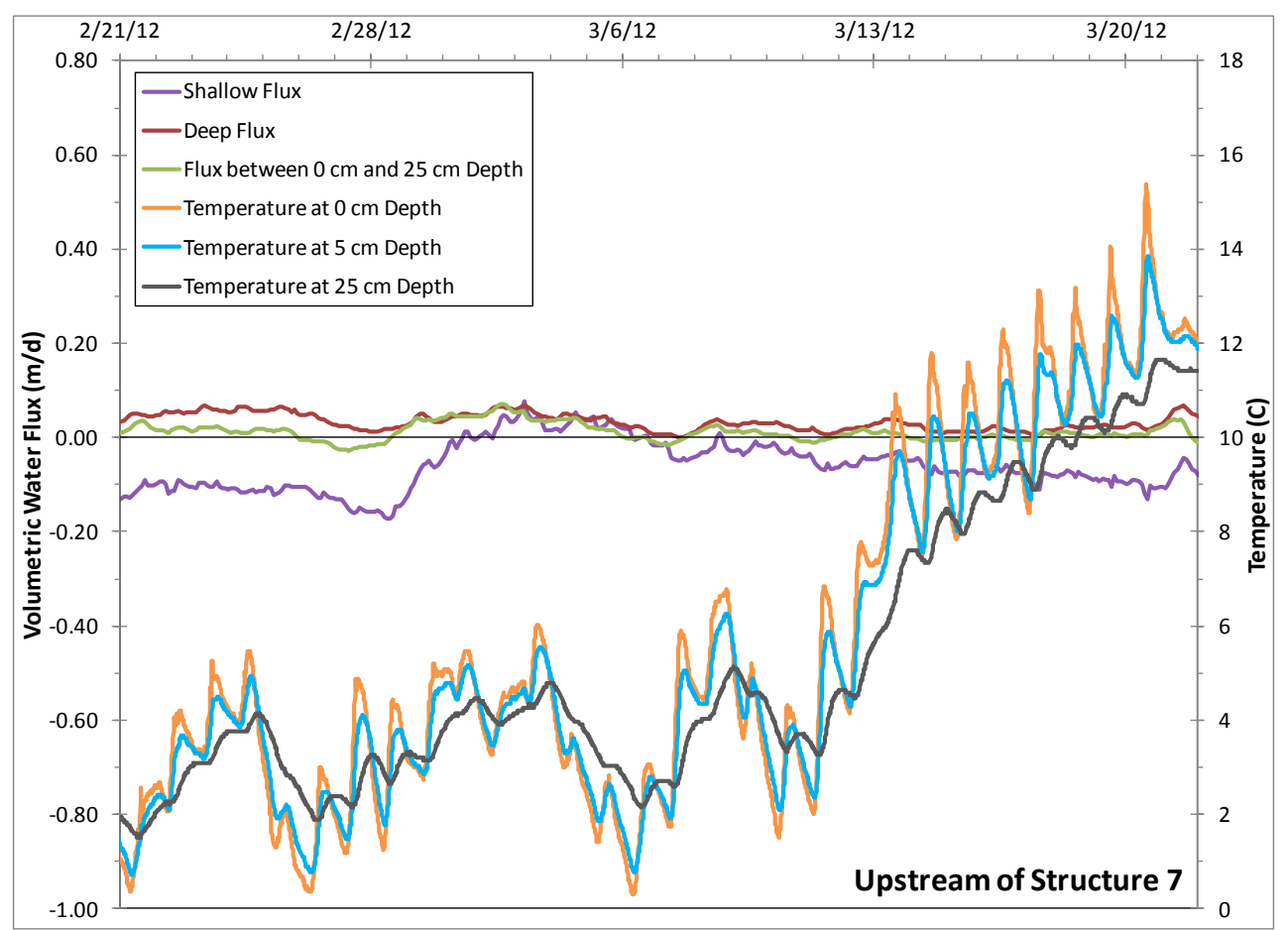

Figure D5: Temperature time series for 3 iButtons and hyporheic fluxes upstream of Structure 7. Positive flux values indicate downwelling, and the horizontal line at zero represents static flux.

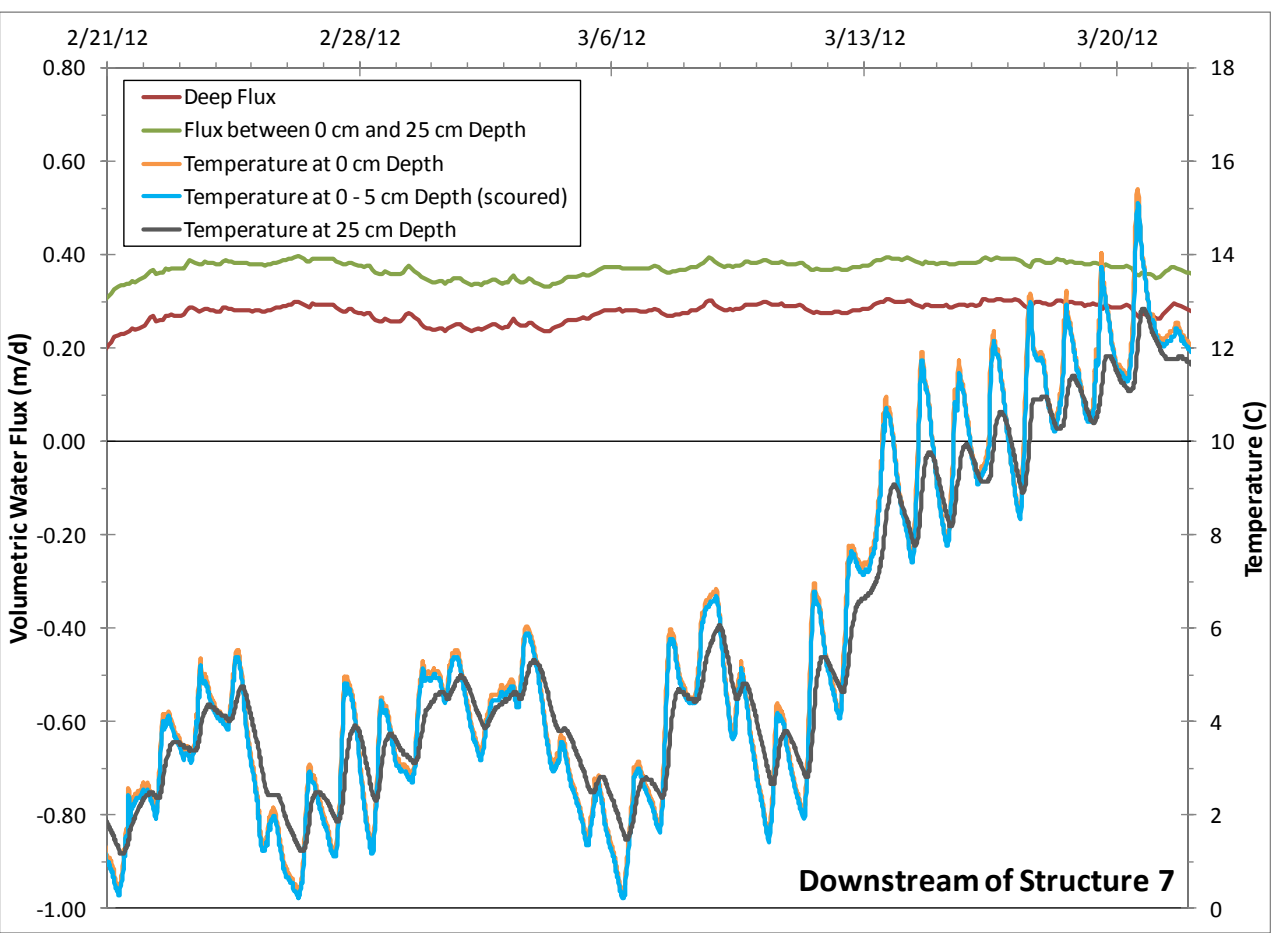

Figure D6: Temperature time series for 3 iButtons and hyporheic fluxes downstream of Structure 7. Positive flux values indicate downwelling, and the horizontal line at zero represents static flux. 


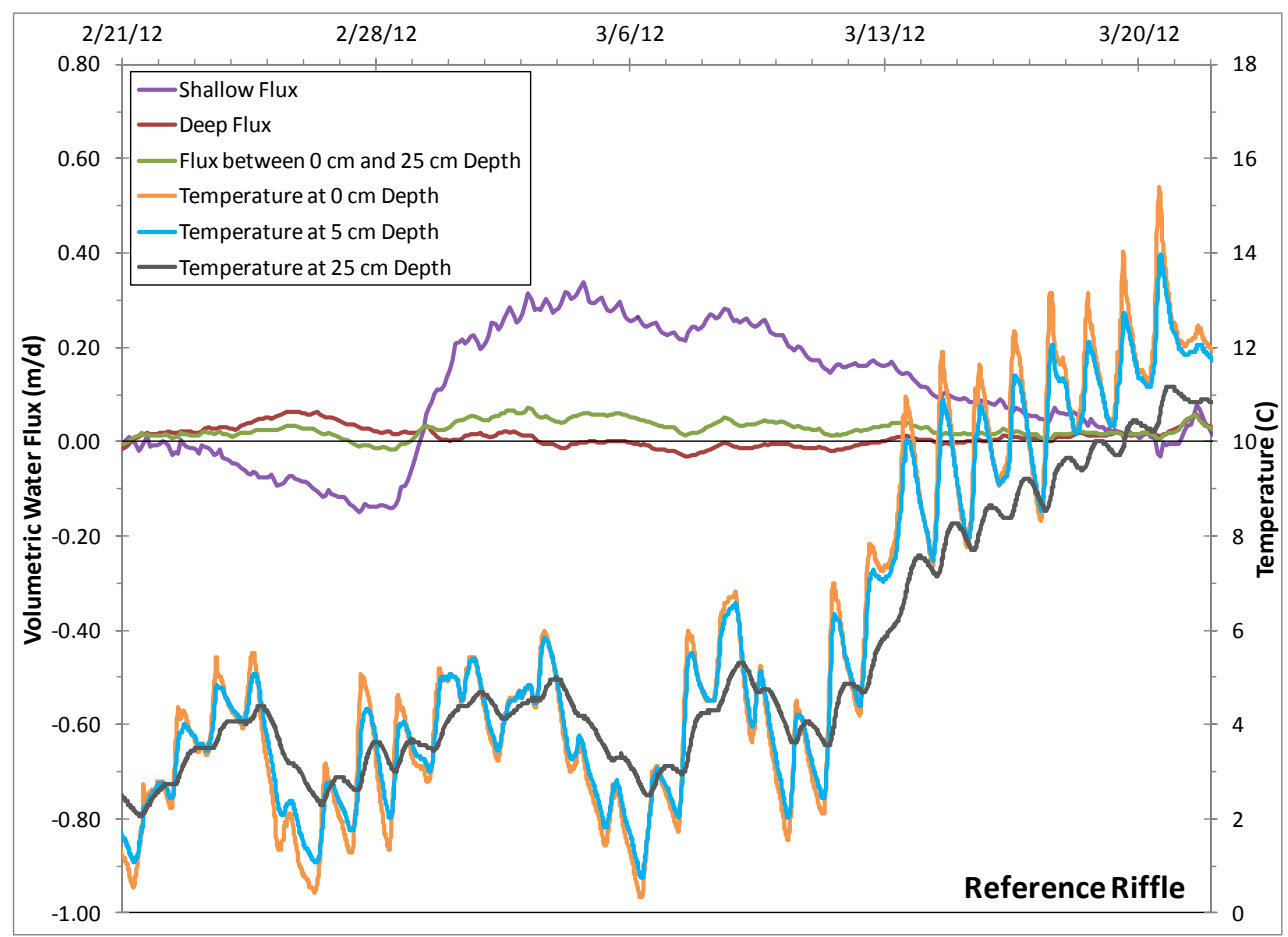

Figure D7: Temperature time series for 3 iButtons and hyporheic fluxes at the reference riffle. Positive flux values indicate downwelling, and the horizontal line at zero represents static flux. 